\title{
ENESEMÄÄRAMISE PALEUS JA PRAGMAATIKA: TARTU VERSUS PARIIS*
}

\author{
Hent Kalmo
}

Tartu rahulepingu tähtsust Eestile pole tarvis rõhutada. Ent sageli mainitakse lepingu murrangulisust ka Euroopa või koguni maailma ajaloos. Nõukoguliku tõlgenduse järgi purustati Tartus noore Nõukogude vabariigi ümber koondatud diplomaatiline blokaad ja pandi alus rahule Ida-Euroopas. ${ }^{1}$ Seda saavutust tõstis esile ka Ants Piip: "Eesti rahuleping oli esimene pääsukene Ida-Euroopa rahu jaluleseadmisel ja selles on temal määratu üldajalooline tähtsus". ${ }^{2}$ Kohe pärast lepingu sõlmimist ennustas Piip sellele pikka iga. Tartu rahu olevat õiglane, nii Eesti kui ka Venemaa huvide peegeldus, mitte ühe poole diktaat. Seetõttu ei ähvardavat seda Versailles' rahulepingu saatus, mille kohta Piip ütles juba 1920. aasta aprillis, et see oli muutunud arheoloogiliseks dokumendiks. Kahe rahulepingu põhimõtted olevat täiesti erinevad. ${ }^{3}$ 1930. aastate keskpaigas sai Piip rahuloluga nentida, et tal oli olnud õigus. Eesti ja Nõukogude Venemaa vahelisele lepingule polevat langenud osaks muutuda paberilipakaks, nagu mitmele teisele sõjajärgsele leppele. ${ }^{4}$

Kuid millised olid siis need põhimõtted, mille kohta arvati, et need tegid Tartu lepingu õiglaseks rahuks? Nõukogude 1930. aastate käsitluses olid need "oktoobrirevolutsiooni loosungid, mis kuulutasid kõigi rahvaste õigust vabale enesemääramisele kuni täieliku lahkulöömiseni riikidest, mille alla nad seni on kuulunud." ${ }^{\prime 5}$ Nii Eesti kui ka Nõukogude vaatevinklist oli Tartu rahuleping otsekui vastand Pariisi rahukonverentsil kujundatud süsteemile - alternatiivne eeskuju tervele ilmale. 1920. aastate künnisel ja hiljemgi paigutusid Tartu rahulepingu tõlgendused laiemasse arutelusse - või propagandaheitlusse - küsimuse üle, millisel viisil ja milliste põhimõtetega tuleks

\footnotetext{
* Uurimistööd on finantseerinud Eesti Teadusagentuur (PRG 942).

"Mida arvatakse Venemaal Eesti-Vene rahulepingust", Päevaleht, 04.02.1935, 3.

Ants Piip, "Tartu rahu vaim”, Postimees, 03.02.1936, 2.

3 Rahvusarhiiv (edaspidi RA), ERA.1624.1.10, 1. 127: Ants Piibu märkused Tartu rahulepingu kohta.

4 Piip, "Tartu rahu vaim", 2.

5 "Mida arvatakse Venemaal Eesti-Vene rahulepingust", 3.
} 


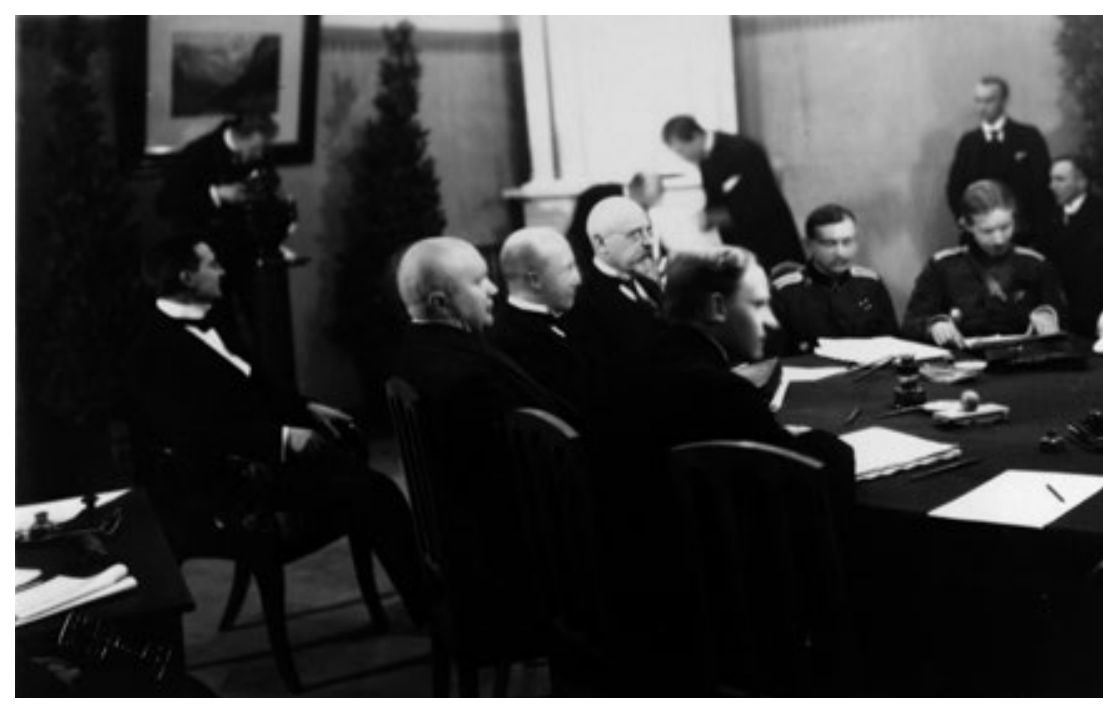

Joonis 1. Eesti delegatsioon Tartu rahuläbirääkimistel. Istuvad: (alates esiplaanist) Aleksander Oinas, Mait Püüman, Ado Birk (lauast eemal), Julius Seljamaa, Jaan Poska, Jaan Soots, Viktor Mutt. RA, EFA.3.0.52359

tagada üleüldine püsiv rahu. Moskva jutustuse järgi püstitati Pariisis küll enesemääramise loosung, ent tegelikkuses lääne suurriigid sellest välja ei teinud. Kommunistliku Internatsionaali esimesel kongressil märtsis 1919 kuulutati, et Wilsoni Rahvasteliit on röövellik ja imperialistlik organisatsioon. ${ }^{6}$ Tartus Vene delegatsiooni juhtinud Adolf Joffe nimetas lepinguga saavutatud peavõiduks seda, et tõendati Nõukogude võimu erinevust silmakirjalikest lääneliitlastest. ${ }^{7}$ Eestis vaadati asjadele mõistagi teisiti. Ent siingi kujunes mulje, et Tartu rahuga pandi maksma väikerahva õigus, mida Pariisis oli lubadustest hoolimata eiratud.

Nõnda ei ole Tartu rahu laiem tähtsus seotud üksnes mõjuga poliitilisele olustikule. See kuulub ka rahvusvahelise õiguse ja isegi poliitilise mõtte ajalukku. Ometi on enesemääramise õiguse mainimine selles ja teistes Nõukogude Venemaaga 1920. aastal sõlmitud rahulepingutes rahvusvahelise õiguse ajaloos pea unustatud peatükk, nagu Lauri Mälksoo on hiljuti tõdenud. Mälksoo sõnul väärib see teema uurimist seda enam, et need lepingud "olid "oma ajast ees" [sest] tunnustasid eraldumisõigust,

6 Selle kongressi kohta vt Donald I. Buzinkai, “The Bolsheviks, the League of Nations and the Paris Peace Conference, 1919", Soviet Studies, 19 (1967), 259.

7 "Mis Joffe Tartu konverentsist jutustab", Tallinna Teataja, 18.02.1920, 1. 
mida Rahvasteliidus sõnastatud üldine rahvusvaheline õigus veel ei sisaldanud." Eeldades, et enesemääramise põhimõttele viidati Tartu rahulepingus Nõukogude esindajate soovil, esitab Mälksoo huvitava küsimuse: mis oli selle sammu ajend? Ta pakub kaks seletust. Esiteks oli Eesti oma iseseisvuse sõjaliselt kätte võidelnud ning leping pidi selle tõsiasjaga arvestama. Teiseks “vajas Nõukogude võim 1920. aastal viidet rahvaste enesemääramisele Venemaa sisemiseks õigustuseks: põhjendamaks kodanikele, kes lähtusid Vene keisririigi territoriaalsest terviklikkusest, miks enamlaste valitsus "andis ära" või loovutas alad, mis keisririik oli minevikus omandanud." Allpool näidatakse, et enesemääramise põhimõttele soovisid Tartu rahulepingus viidata teineteisest sõltumata nii Eesti kui ka Venemaa esindajad. Ent just seetõttu võib ka Eesti kohta küsida: miks? Kas Eesti esindajad ei tahtnud samuti rahulepinguga kõnetada kedagi, kes Tartus läbirääkimiste laua taga ei istunud?

Artikli eesmärk on näidata, et Tartu rahuläbirääkimised olid nii Eestile kui ka Nõukogude Venemaale laiema kõlapinnaga diplomaatiline samm, mitte pelgalt tee kahepoolse kokkuleppeni. Nõukogude võim valmistas pinda kapitalistlike riikidega kooseksisteerimiseks. 1919. aasta septembrist alates peeti pidevalt silmas rahu väljavaadet Suurbritanniaga. "Igal Tartus lausutud sõnal oli vastukaja Thamesi kallastel," seletas hiljem välisasjade rahvakommisar Georgi Tšitšerin, andmaks aimu maailmaajaloolisest tähtsusest, mida Moskva omistas Eestiga peetavatele kõnelustele. ${ }^{9}$ Ka Eesti delegatsiooni juht Jaan Poska arvestas kaugemate eesmärkidega. Ta nägi rahukõnelustes vahendit, mille abil hankida lääneriikide de jure tunnustus. Pariisi rahukonverents oli toonud pettumusi, kuid Poska silmis olid Tartu läbirääkimised läänesuunalise diplomaatia jätk, mitte selja pööramine sellele. Enesemääramine oli keskne mõiste nii Eesti kui ka Nõukogude diplomaatias: Eesti nõutas enesemääramise õiguse toel läänest tunnustust, Moskva pidas vajalikuks lubada selle õiguse teostumist endise Venemaa lääneosas, et saavutada kokkulepe ja majanduslik koostöö Suurbritanniaga. Seega toob just enesemääramise õiguse mainimine Tartu rahulepingu II artiklis kõige paremini esile kahe poole püüdluste kokkupuutepunkti 1920. aasta alguses. Teisalt on see suurepärane näide sellest, kuidas ühine mõiste varjab vastuokslikke vaatenurki. Mitte et Eesti oleks suhtunud enesemääramise põhimõttesse idealismi ja Nõukogude Venemaa küünilise

8 Lauri Mälksoo, "The Soviet Approach to the Right of Peoples to Self-determination: Russia's Farewell to jus publicum europaeum", Journal of the History of International Law, 19 (2017), 10-11.

9 Georgiı̆ Vasil'evich Chicherin, Stat'i i rechi po voprosam mezhdunarodnoŭ politiki (Moskva: Sotsékgiz, 1961), 141. 
pragmatismiga. Pigem ilmestavad mõlemad vaatenurgad tõika, et idealism ja pragmaatika polegi selle põhimõtte puhul teineteisest lahutatavad.

Tartu rahukonverentsi eellugu on valgustatud mitmest küljest. ${ }^{10}$ Samuti on pälvinud rohket tähelepanu enesemääramise põhimõtte tarvitamine toonases diplomaatias, muuseas Eesti välispoliitikas. ${ }^{11}$ Kuna seda põhimõtet kiputakse siiani seostama Woodrow Wilsoniga, siis on mõistetav, et ajaloolased on katsunud selgitada, milline oli selle tegelik roll Ameerika Ühendriikide poliitikas. ${ }^{12}$ Ka Lenini lähenemist enesemääramisele on valdavalt käsitletud võrdluses Wilsoni omaga, rõhutades selle ajalist eelnevust. ${ }^{13}$ Artiklis on valitud teine suunitlus. Enamlaste enesemääramisdoktriini kujunemist vaadeldakse kõrvuti Eesti püüdlustega. Sellega kaasneb mitu eelist. Esiteks tuleb nõnda esile tõik, et see doktriin juurdus arutlustes Venemaa riikliku korralduse üle. Just Soome- või Eesti-taoline väikeriik mõlkus Leninil meeles 1917. aasta kevadel, kui ta nõudis eraldumisvõimaluse tunnustamist parteiprogrammis (nagu allpool näidakse, oli see pigem taktikaline samm kui väikeriikluse soosimine). Hiljem sai Eestist aga juhtum, mille puhul avaldus eriti selgelt enamliku enesemääramisdoktriini rivaliteet teiste käsitlustega, sh Wilsoni omaga. Õigupoolest

10 Heino Arumäe, “Jaan Poska tee Tartu läbirääkimisteni”, Jaan Poska oma ja meie ajas (Tallinn: Konstantin Pätsi Muuseum, 2010); Eero Medijainen, "Jaan Poska ja Eesti välisdelegatsioon”, Jaan Poska oma ja meie ajas (Tallinn: Konstantin Pätsi Muuseum, 2010); Heino Arumäe, Eesti ja Soome: sõjast sõjani (Tallinn: Argo, 2018); Magnus Ilmjärv, "Balti küsimus Pariisi rahukonverentsi eel ja ajal 1918-1920", Acta Historica Tallinnensia (2019), 25; Edgar Mattisen, Tartu rahu (Tallinn: Eesti Raamat, 1989).

$11 \quad$ Mart Kuldkepp, "Rahvusliku enesemääramise kaudu Saksamaa külge: eestlased anneksionistliku Saksa poliitika sihtmärgina 1918. aasta okupatsiooni eel”, Esimene maailmasõda ja Eesti II, toim Tõnu Tannberg (Tartu: Eesti Ajalooarhiiv, 2016); Hent Kalmo, "Enesmääramise saatuslik tund", Iseseisvusmanifest: artikleid, dokumente ja mälestusi, toim Ago Pajur, Tõnu Tannberg (Tartu: Rahvusarhiiv, 2014); vt ka Karsten Brüggemann, “"Enesemääramine lastetoas?” Vene nägemus Eestist revolutsiooni ja kodusõja ajal”, Vene aeg Eestis: uurimusi 16. sajandi keskpaigast kuni 2o. sajandi alguseni, toim Tõnu Tannberg (Tartu: Eesti Ajalooarhiiv, 2006); Eva Piirimäe, "Enesemääramise idee ajalugu", Sirp, 23.02.2018.

12 Enesemääramise põhimõtte kohta seoses Eestiga vt Olavi Arens, "Wilson, Lansing ja Hoover - Ameerika välispoliitika ja Eesti riigi tekkimine”, Acta Historica Tallinensia (2006), 10; Olavi Arens, "United States policy toward Estonia and the Baltic States 19181920 and 1989-1991", Ajalooline Ajakiri, 3/4 (2016); David S. Foglesong, "The United States, self-determination and the struggle against Bolshevism in the Eastern Baltic regioon, 1918-1920", Journal of Baltic Studies, 2 (26) (1995); Eero Medijainen, "Enesemääramise udus: Eesti ja Ameerika Ühendriigid 1918-1919”, Ajalooline Ajakiri, 1 (2016).

13 Jörg Fisch, Das Selbstbestimmungsrecht der Völker: Die Domestizierung einer Illusion (C. H. Beck, 2010), Borislav Chernev, "The Brest-Litovsk Moment: Self-Determination Discourse in Eastern Europe before Wilsonianism", Diplomacy and Statecraft, 2 (22) (2011); Borislav Chernev, Twilight of Empire. The Brest-Litovsk Conference and the Remaking of East-Central Europe, 1917-1918 (University of Toronto Press, 2017), 66. 
ei soovinudki enamlased 1919. aasta sügisel kaitsta mõnd erilaadset arusaama enesemääramisest, vaid püüdsid näidata, et ainult nemad tunnustavad tegudega õigust, mille kohta teised teevad kõigest ilusaid sõnu. See oli 1917. aastal Venemaal viljeldud revolutsioonilise taktika laiendamine kogu maailmale. Eesti ja teiste läänenaabrite sõjalise ründamisega 1918. aasta lõpus oli sisuliselt loobutud ideoloogilisest võitlusest ja tehtud panus jõule. Tartu rahuleping tähistas enamlaste naasmist endisele rajale. Enesemääramise õiguse mainimine selles lepingus oli märk uuest poliitikast, mis pidi ühendama "rahuliku kooseksisteerimise", üleilmse ideoloogilise võitluse ja revolutsiooni õhutamise rööbiti tavapärase diplomaatiaga. Kuna selline taktika jäi Nõukogude võimule üldjoontes iseloomulikuks mitmeks aastakümneks, siis tuleks Tartu rahulepingu sõlmimist pidada üheks 20. sajandi võtmesündmuseks.

\section{Enesemääramine kuni lahku löömiseni}

"Õiguse elu on võitlus." ${ }^{14}$ Nende sõnadega avas Jaan Tõnisson 3o. oktoobril 1905 Tartus näitustehoonesse kogunenud rahvakoosoleku, mis pani aluse Eestile kui poliitilisele üksusele. Koosolekuid oli sel aastal peetud palju. Ka 17. oktoobri tsaari manifestiga loodud olukorrast oli juba kõneldud. Ent näitustehoones esitati murranguline mõte moodustada tervet Eesti rahvast esindav "ülemaaline" kogu. Rahva asuala pinnal sai kontuurid kubermangupiire ületav "Eesti". Niisugune vaimne kuvand oli erinevate nimetustega ("kodumaa", "isamaa", "Eestimaa", "Eesti rahva maa") pikkamisi kinnistunud juba 19. sajandi teisel poolel. Nüüd muutus see aga selgemalt poliitilise mõtte ja tegevuse lähtekohaks. Koosolekul nõuti "meie oma rahvale, nagu ka teistele rahvastele, enese-määramise õiguse alusel kohalikku sisemist omavalitsust." ${ }^{15}$ Peterburist saabunud dr Peeter Hellat ütles, et eestlastel peab olema "oma asjade ajamiseks Eesti parlament."16 Ehkki varsti hakati nõudma tagasihoidlikumalt üksnes kultuurilist enesemääramist, säilis seos autonoomse omavalitsusega, mis lubaks "kodumaa elus [...] meie oma paremat tundmist mööda ise otsustada”. ${ }^{17}$

\footnotetext{
14 "Rahvakoosolek poliitiliste õiguste pärast", Postimees, 03.11.1905, 2.

Ibid.

"Rahvakoosolek poliitiliste õiguste pärast", Postimees, 01.11.1905, 1.

Seda nimetati 1905. aastal asutatud eduerakonna põhimõtete hulgas, vt "Mõtte pärast”, Postimees, 19.12.1905, 1.
} 
Autonoomia ei olnud 1905. aastal siinmail uus mõiste. See kuulus baltisaksa poliitilise mõtte tuumideede hulka. ${ }^{18}$ Jaan Unduski sõnul oli autonoomiaprintsiip "baltiliku olemise telg, [...] baltlastelt eestlastele - olgu või vastutahtsi - transleeritud vaimne vundament, millele rajati hiljem Eesti riik". ${ }^{19}$ Balti provintside omavalitsuse-taotlust polnud põhjendatud mitte ainult ajalooliste õigustega, vaid ka nende alade kultuurilise omapäraga, mida ajuti käsitati rahvuslikus, saksapärasuse võtmes. ${ }^{20}$ See oli pealesunnitud hoiak, uue ajaga kohanemise väljakutse, kui rahvustunne oli tõesti, nagu 1869. aastal tõdeti, "maailmaajalooline ratas, mis pöörleb ja mida keegi ei suuda peatada." ${ }^{21}$ Vastutahtsi või mitte, eestlased ehitasid tõesti sellele vundamendile. Kuid enesemääramise põhimõte, mis 1905. revolutsiooni keerus leidis Venemaal laia kõlapinna, lõhkus siiski baltluse traditsioonilisi aluseid. Saksapärasust toodi ette peamiselt olemasoleva õigustuseks. Läänemere kubermangude ühendamine või liitumisvõimalus Saksamaaga, kui need üldse kõneks võeti, jäid varitsema saksakeelsete mõtteavalduste äärealadele. Eestlaste oktoobrikuine koosolek kutsus aga ülemaalise rahvakoosoleku kokku selleks, et saada teada "terve rahva tahet". Eesti rahva piire polnud olemasolev õiguslik korraldus veel kinnistanud. Nii visati enesemääramise nimel õhku hoopis kombatavam võimalus, et tahetakse muuta kubermangude piire - ja kes teab, mida veel. Millise õigusega oleks tahetavat siis Eesti rahvale keelatud?

Pole üllatav, et ka Vene keskvõimu kaitsjad ehitasid vanale vundamendile ja süüdistasid eestlasi separatismis, mida baltisakslastele oli aastakümneid ette heidetud. ${ }^{22}$ Tõnisson rõhutas 1905. aasta järel korduvalt, et

18 Carl Schirren nimetas autonoomiat Venemaa läänemereprovintside eluprintsiibiks, vt Livländische Antwort an Herrn Juri Samarin, 3. väljaanne (Lepizig: Verlag von Duncker \& Humblot, 1869), 95.

19 Jaan Undusk, "Ajalootõde ja metahistoorilised žestid. Eesti ajaloo mitmest moraalist", Tuna, 2 (2000), 120.

20 Eriti kammitsemata tehti seda nt raamatus Das Zerstörungswerk in den Russischen Ostseeprovinzen (Berlin: Verlag von A. Deubner, 189o), 4-5. Vt ka W. v. Rohland, Das baltische Deutschtum (Leipzig: Verlag von Duncker \& Humblot, 1906), 15-16.

${ }_{21}$ Georg Bergholzi kiri paruness E. von Radenile, 29.05.1869, tsiteeritud raamatus: Heinrich Schaudinn, Das Baltische Deutschtum und Bismarcks Reichsgründung (Lepzig:

J. C. Hinrichs'sche Buchhandlung, 1932), 81.

22 Ligi pool sajandit varasemate kahtlustuste kohta vt "Die Anklage auf Separatismus", Baltische Monatschrift, kd 10, 1864, 353-362. Kirjutati, et igal kura-eesti-liivimaalasel on veres õilis "tung omavalitsusele", mis õigustavat soovi luua ühine kubermang. Vaevalt oleks mõnel baltisakslasel sel ajal veidra utoopianagi pähegi torganud, et ajalooratas sõidab mõned aastakümned hiljem nende omavalitsusest selle sama nõudega üle. Toona nimetati isegi seda eluvõõraks unistuseks, et eesti keel võiks tõusta kultuurkeeleks, vt “Zur Nationalitätenfrage”, Baltische Monatschrift, kd 9, 1864, 572. Ometi idaneb tulevik märkamata. Selsamal 1864. aastal arutati eestlaste palvekirja koostamise ajal ka palvet 
enesemääramise püüdlustega ei taha eestlased Venemaast eralduda. Siht ei olnud "Eestimaa lahtikiskumine Vene ilmariigi küljest ja iseriigi asutamine Lääneriigi kaldal." ${ }^{23}$ 1905. aastal olevat väljend "Eesti vabariik" mõnel rahvakoosolekul tõesti kõlanud. Siiski anti endale aru, et võitlusest sündiv õigus võib võitluses ka surra. Sest milline saatus langenuks osaks iseseisvale kodumaale? "Raskuse- ehk gravitatsioniseaduse järele peaks tingimata mõni suurem keha teda oma mõju piirkonda kiskuma.” Enesemääramise õigus sai siinmail tähenduse geograafialt - Eesti olevat mõistetud Sarmaatia rannikut valitseva võimu rüppe. Mõneks ajaks tuhmus unistus autonoomiastki. 1906. aasta Venemaa põhiseaduse preambulis sätestati, et riik on ühtne ja jagamatu. Paljudele muutus see väljend kreedoks, mis välistas iga järeleandmise rahvusliku omavalitsuse suunas. ${ }^{24}$

Ilmasõja puhkemisel, kui tsaar lubas autonoomiat Poolale, tärkas eestlaste lootus taas. "[M]eie ei või silmapilkugi kahelda," kirjutati 1915. aasta suvel, "et tõde, mis ühe rahva kohta maksvaks seatakse, teiste rahvaste kohta valeks jääb." ${ }^{25}$ Tõde, millest kõneldi, oli sõja jätkudes üha enam pinda võitev enesemääramise loosung. ${ }^{26}$ Viimase levimisele andsid otsustava tõuke sotsiaaldemokraatide rahuprogrammid. Saksamaal oli Sotsiaaldemokraatlik Partei (SPD) esiotsa üsna üksmeelselt toetanud valitsust, õigustades sõjapidamist riigi kaitsmise vajadusega. Parteis ilmnesid aga suuremad lahkhelid, kui Saksamaa kantsler Bethmann-Hollweg vihjas 1915. aasta juunis territooriumide annekteerimise võimalusele. ${ }^{27}$ Kas sotsialistid võisid toetada ka vallutussõda? SPD juhtkond koostas ringkirja, milles rõhutati, et

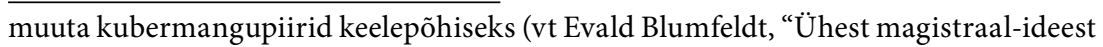
Eesti ühiskondliku mõtte ajaloos poolsajandil enne 1917. aasta veebruarirevolutsiooni”, Eesti Teadusliku Seltsi Rootsis Aastaraamat, kd 8 (Stockholm, 1980), 18. Cornelius Hasselblatt on väitnud, et selliste 19. sajandil esitatud palvete seostamine hilisema omariiklusega on konstruktsioon, mis sünnib "teleoloogilise ajaloonägemuse tagajärjel” ("1881. aasta müüt", Tuna, 3 (2015), 144). See pole tingimata nii, sest uurimine võib olla ka genealoogiline. Jätta kõrvale seosed "ülemaalise rahvaasemike koosoleku” kokkukutsumise ja varasemate kubermangupiire ületavate-tühistavate mõtete kujunemise vahel tähendaks sulgeda silmad kontekstile, mis on vajalik 1905. aasta sündmuste mõistmiseks. Sama võib öelda ka nt 1918. aasta veebruarimanifesti kohta, milles on ümbervormitud kujul leitavad just 1860. aastatel piirjooni omandama hakanud ideed Eesti rahvast kui kollektiivsest tegutsejast-kannatajast.

23 “200-aastase mälestuse-päeva puhul”, Postimees, 05.07.1910, 1.

24 Violet Conolly, "The 'nationalities question' in the last phase of tsardom”, Russia Enters the Twentieth Century, 1894-1917, toim George Katkov jt (London: Temple Smith, 1971), 153 .

25 "Autonomia", Tallinna Teataja, 23.07.1915, 2.

26 Ibid.

27 Carl E. Schorske, German Social Democracy 1905-1917. The Development of the Great Schism (Cambridge, MA: Harvard University Press, 1955), 304. 
Saksamaa huvides on püsiv rahu. Vallutuspoliitika olevat lühinägelik, kuna ei arvesta tõigaga, et rahvusele võoraste (volksfremder) alade annekteerimine (ja sellega kaasnev enesemääramise õiguse rikkumine) kahandab Saksa rahva ühtsust ja jõudu. ${ }^{28}$ SPD ringkiri loetles püsiva rahu tingimusi nii pehmelt ja nii Saksamaa-keskselt, et sel polnud väljavaadet leida rahvusvahelist poolehoidu isegi sotsialistide seas. Hoopis mõjukamaks osutus paar nädalat hiljem Šveitsis Zimmerwaldi konverentsil koostatud manifest, milles nõuti rahu ilma igasuguste (ka varjatud) anneksioonideta ning tõsteti esile enesemääramise õigust kui rahvastevaheliste suhete vankumatut alust. ${ }^{29}$ Zimmerwaldi manifesti sõnastus oli küll resoluutne, kuid jättis siiski palju tõlgendamisruumi. Teisiti ei saanudki olla, sest kümnest riigist pärinevad delegaadid poleks suutnud jõuda kokkuleppele selles, mida enesemääramise õigus täpsemalt tähendab. Venemaa delegatsiooni liige Lenin oli pea ainus, kes kinnitas, et sellest ei tulene mitte üksnes anneksioonide keeld, vaid ka õigus eralduda juba olemasolevast riigist. Teisisõnu ei pidavat rahutingimused kaitsma mitte sõjaeelset status quo'd, vaid looma tõeliselt demokraatliku poliitilise korralduse. "Konkreetselt tähendab see poliitilise demokraatia nõudmine täielikku vabadust agiteerida lahkulöömise poolt ja lahkulöömise küsimuse otsustamist lahkulööva rahvuse referendumiga." Lenini sõnul pidid sotsialistid agiteerimise vabadust kasutama selleks, et veenda rahvaid ühinema, mitte väikeriike moodustama. Kuid ilma lahkulöömise vabaduseta ei saanud olla vabatahtlikku rahvaste ühinemist. Just eraldumise võimalus soodustab suurriiklust, väitis Lenin. "Mida lähedasem on demokraatlik riigikord täielikule lahkulöömisvabadusele, seda harvemad ja nõrgemad on tegelikult lahkulöömise püüdlused, sest suurriikide eelised on nii majandusliku progressi seisukohast kui ka rahvahulkade huvide seisukohast kaheldamatud, kusjuures need ühes kapitalismi kasvuga järjest suurenevad."30

Kuigi enesemääramise õigus paistis olevat takistus vallutussõjale, leidis Saksamaa valitsus, et seda saab tarvitada sootuks vastupidiselt: kui kohalik rahvas oli liitmisega nõus, siis ei kujutanudki alade hõlvamine idas endast justkui anneksiooni. Nõnda tunduski 1917. aastal korraga, nagu ei oleks "rahvaste vaba enesemääramise õigusel vastaseid: selle poolt räägivad

28 Philipp Scheidemann, Der Zusammenbruch (Berlin: Verlag für Sozialwissenschaft, 1921), 27.

29 Zimmerwaldi konverentsi kohta vt R. Craig Nation, War on War. Lenin, the Zimmerwald Left, and the Origins of Communist Internationalism (Durham, London: Duke University Press, 1989), 66.

30 Vladimir I. Lenin, "Sotsialistlik revolutsioon ja rahvuste enesemääramise õigus" [1916], Teosed, kd 22 (Tallinn, 1953), 134. 
kõik, algades suurriikide imperialistliste valitsustega ja lõpetades äärmiste sotsialistliste erakondadega." ${ }^{31}$ Kevadel võtsid nii Petrogradi Nõukogu kui ka Venemaa Ajutine Valitsus omaks nõudmise, et käimasolev sõda lõpetataks ilma anneksioonide ja kontributsioonideta, tunnustades rahvaste õigust enesemääramisele. Eriti teravaks osutus küsimus, mida see õigus tähendab Venemaa sees. Mai keskel toimunud kadettide VIII kongressil raius Pavel Miljukov: "Riigi jagamine suveräänseteks, iseseisvateks üksusteks on partei arvates täiesti vastuvõetamatu." ${ }^{32}$ Rahvuslike territoriaalsete üksuste loomine polevat välistatud, kuid sellele saavat mõelda alles tulevikus. Sotsialistlikud parteid olid vähemalt sõnades lahkemad. Esseerid toetasid koguni föderatiivset vabariiki. Enamlased läksid veelgi kaugemale. Enesemääramise õigus ilutses juba nende 1903. aasta programmis. Juunis peetud esimese ülevenemaalise nõukogude kongressi delegaadid kuulutasid, et tahavad rahvaste enesemääramise põhimõtte ellu viia nii sise- kui ka välispoliitikas "suurimal võimalikul määral". Vormelile lisati sõnad "kuni lahkulöömiseni". Täpsustati siiski, et eraldumine peab toimuma "kokkuleppel üldrahvaliku Asutava Koguga". ${ }^{3}$

Enamlaste seisukoht oli erandlik. 1917. aastal kevadel-suvel ei seostunud enesemääramise põhimõte sugugi lahutamatult riikliku iseseisvusega. Ka avaras omavalitsuses nähti selle paleuse teostamise vormi. Eesti saigi nüüd oma parlamendi. Ajutine Maanõukogu oli ehitatud ajaloolise omavalitsuse vundamendile, kuid balti traditsioone murendavalt. Seda hakati kohe kirjeldama Eesti rahva esindusena. Jaan Poska, Eesti kubermangu komissar, ütles Maanõukogu avamisel, et nüüd algab "kodumaa" - mis polnud balti Heimat - "elus ja ajaloos uus tähtis ajajärk. Uks, mis sada-aastate jooksul seitsme pitsari taga meie ees kinni seisis, on täna lahti läinud ja terve rahva esitus astus temast sisse, et maavalitsemist oma kätte võtta." Poska sõnul tuli Vene riigis luua selline kord, "et üksikute rahvaste enesemääramise õigus kõige laiemal mõõdul ära kasutatud võiks saada ja seal juures terve rahva ühisus ja tema juur selle all mitte ei kannataks." ${ }^{\prime 34}$ Et balti autonoomia juur välja tõmmati, selles ei nähtud mitte kadu, vaid reparatsiooni - sügavama ajaloolise järjepidevuse taastamist. Maanõukogu töölehakkamisega kaasnenud rõõm ei kestnud aga kaua. Mida suuremaks oli paisunud lootus saada tunnustatud võrdväärse osariigina

\footnotetext{
31 P. R., "Rahvaste enesemääramise õigus", Päevaleht, 05.06.1917, 1.

32 Väljavõte Miljukovi kõnest kadettide VIII kongressil, Rech, 10. mai: Semën Dimanshteĭn, Revolyutsiya $i$ natsional'nȳı vopros: dokumenty $i$ materialy po istorii natsional'nogo voprosa $v$ Rossii i SSSR $v$ XX veke (Moskva, 1930), 79.

33 Resolutsiooni teksti vt Dimanshteĭn, Revolyutsiya i natsional'nȳı vopros, 114-115.

34 Maanõukogu protokollid 1917-1919 (Toronto, 1990), 1.
} 
demokraatlikus Vene föderatsioonis, seda suurema pettumuse valmistasid märgid, et loosungitest hoolimata polnud keskvõimu üleolev suhtumine väikerahvastesse kuhugi kadunud. Ajutine Valitsus viivitas pikalt täpsustamisega, kuidas rahvuste vabadus tulevasel Venemaal ikkagi tagatakse. Alles septembri lõpus avaldati kauaoodatud deklaratsioon rahvaste enesemääramisest. See oli hoopis ettevaatlikum sellest, mida tõotasid sotsialistlikud erakonnad. Föderatsioonist polnud juttugi, rääkimata lahkulöömisest. Piirduti teadaandega, et iga Venemaa rahvuse enesemääramise õigust tunnistatakse "alustel, mille töötab välja Asutav Kogu" ${ }^{35}$

Lenin oskas suurepäraselt hinnata enesemääramise loosungi propagandaväärtust olukorras, kus Ajutise Valitsuse tegevus paistis üha enam ilmutavat vanale korrale iseloomulikku suurvene šovinismi. Isegi enamlaste hulgas oli suur vastuseis tema arvamusele, et rahvaste enesemääramise õigusest tuleneb vaba voli emamaast lahku lüüa. Lenin püüdis kõhklevaid erakonnakaaslasi veenda väitega, et abstraktse õiguse tunnustamine ei tähenda veel ühe või teise rahvuse lahkulöömise toetamist konkreetsel juhul. Proletariaat tunnustavat küll kõigi rahvuste võrdset õigust omariiklusele, kuid hindavat siiski iga eraldumiskatset "klassivõitluse vaatevinklist". ${ }^{36}$ Ja kui mõni rahvas otsustabki eralduda, siis kujutavat see endast mööduvat episoodi, mille lubamine on vajalik revolutsioonilise lõppsihi saavutamiseks. 1917. aasta aprillis toimunud parteikongressil kaitses Lenin taas seisukohta, et eraldumise õiguse tunnustamine vähendab eraldumise tõenäosust. Soomele tuli anda mitte üksnes autonoomia, vaid täielik vabadus riigi koosseisust lahkuda. Just siis tekkivat soomlastes nii suur usaldus Vene demokraatia vastu, et liidusidemed jäetakse katkestamata. ${ }^{37}$

Pärast oktoobripööret võiski esialgu paista, et enamlased viivad kõik väikerahvastele antud lubadused sõna-sõnalt ellu. Rahvakomissaride Nõukogu andis vahetult pärast ametisseastumist dekreedi, milles tõotas võtta tegevuse aluseks Venemaa rahvaste õiguse vabale enesemääramisele "kuni lahkulöömiseni ja iseseisva riigi moodustamiseni”. ${ }^{88}$ Sellest julgustatuna kuulutas Soome Eduskunta novembri alguses, et võtab võimu Soome territooriumil enda kätte. ${ }^{39}$ Samasuguse otsuse langetas Kiievi Raada. ${ }^{40}$

\footnotetext{
35 Dimanshteĭn, Revolyutsiya i natsional'nȳ̌ vopros, 59.

36 Vladimir I. Lenin, Rahvaste enesemääramise óigusest (Tallinn, 1946 [1914]), 23 (rõhutus ära jäetud).

37 Dimanshteĭn, Revolyutsiya i natsional'nȳı̆ vopros, 16.

38 Dekreedi teksti vt Suur Sotsialistlik Oktoobrirevolutsioon Eestis: dokumentide ja materjalide kogumik (Tallinn, 1957), 131-132.

39 Juhani Paasivirta, Suomen itsenäisyyskysymys 1917, kd 2 (Porvoo, Helsinki, 1949), 133.

40 Richard Pipes, The Formation of the Soviet Union, revised edition (Cambridge, Mass., 1970), 115.
} 
Alguses reageeris Nõukogude valitsus neile otsustele leplike sõnadega. 14. novembril ütles Stalin Soome Sotsiaaldemokraatliku Töölispartei kongressil, et ehkki Petrograd loodab revolutsiooni onnestumisele Soomes, austab ta soome rahva enamuse otsust, milline see ka poleks. ${ }^{41}$ Mõnda aega suhtuti soosivalt ka Kiievi Raadasse. Novembri lópus kinnitas Trotski, et "ülevenemaaline Nõukogude valitsus ei aseta mingeid takistusi Ukraina enesemääramise teele, ükskõik millise kuju see võtab, ning Vene valitsus tunnustab Ukraina vabariiki täielikult ning suurima siirusega". 42

Õige pea nägi pilt aga välja teistsugune. Suhtumine Kiievi Raadasse muutus niipea, kui Ukraina ähvardas muutuda nõukogudevastaste vägede tugialaks. Nüüd väideti, et Rahvakomissaride Nõukogu on valmis tunnustama iga vabariigi iseseisvust - eeldusel, et seda nõuab territooriumi töörahvas. ${ }^{43}$ Kõike seda pandi loomulikult tähele ka Eestis, kus samuti "enamlaste programmi tegelikult tunda" saadi, nagu Poska hiljem väljendus. ${ }^{44}$ "Enamaste politika on valelik olnud igas asjas, mis nad on tõotanud, sest tõotusest pole midagi niiviisi täidetud nagu tõotatud," süüdistas Jüri Vilms detsembri keskel. "Lubatakse täielik enesemääramise õigus ja kui seda luba teostama hakatakse, siis tormatakse selle eest sõjariistus kallale." ${ }^{.45}$ Silmakirjalikkusest hoolimata ei puudunud õiguslik tähendus enamliku valitsuse 2. novembri (vkj) dekreedil, kus mainiti Venemaa rahvaste õigust enesemääramisele kuni eraldumiseni ja iseseisva riigi moodustamiseni. Ants Piip kirjutas hiljem, et see legaliseeris "Vene võimuloleva valitsuse vastu

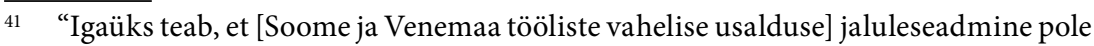
mõeldav ilma soome rahva vaba enesemääramise õiguse otsustava tunnustamiseta. Ning tähtis on siin selle õiguse mitte ainult sõnaline, kuigi ametlik tunnustamine. Tähtis on see, et Rahvakomissaaride Nõukogu kinnitaks seda sõnalist tunnustamist tegudega, et see viidaks kõhklemata ellu. Sest sõnade aeg on möödas.” Jossif V. Stalin, "Helsingis Soome Sotsiaaldemokraatliku Töölispartei kongressil peetud kõne", Teosed, kd 4 (Tallinn, 1948), 3-4. Stalini esinemise tausta kohta vt Tuomo Polvinen, Venäjän vallankumous ja Suomi, kd 1 (Porvoo, Helsinki, 1967), 130-131.

42 Pravda, 26.11.1917, tsiteeritud raamatust Pipes, The Formation of the Soviet Union, 118.

43 Detsembri keskpaigas seletas Stalin, et rahvas, kelle enesemääramise õigust tunnustati, hõlmas töölisi ja soldateid, talupoegi ja madruseid, mitte aga mõisnikke ja kapitaliste, kelle huve Raada Peasekretariaat olevat asunud kaitsma. Teosed, kd 4, 7. 1918. aasta jaanuaris, III ülevenemaalisel nõukogude kongressil rääkis Stalin, et konflikt Raadaga osutas "vajadusele tõlgitseda enesemääramise põhimõtet mitte kui kodanluse, vaid antud rahvuse töötavate hulkade õigust enesemääramisele." See põhimõte pidavat olema sotsialismi eest võitlemise vahendiks ja tulevat allutada sotsialismi põhimõtetele. Ibid., 30.

$44 \quad$ Maanõukogu protokollid 1917-1919, 291.

45 Jüri Vilms, “Enamlaste valitsus ja rahvaste enesemääramine”, Päevaleht, 12.12.1917, 1.
} 
oma riigi väljakuulutamist eestlaste poolt”. ${ }^{46}$ Võimalus Nõukogude ametlikku deklaratsiooni endi huvides kasutada kerkis maanõunike silme ette kohe pärast selle avaldamist, kui arutati, kas ja milleks pöördejärgses olukorras kokku tulla. 11. novembri vanematekogu istungil toetas Piip Tõnissoni ettepanekut, et Maanõukogu peab kuulutama ennast ainuvõimuks ja korraldama Eesti Asutava Kogu valimised. "Kui meile on valitsuse dekrediga enesemääramise õigus antud: "vplot' do otdeleniya” [kuni eraldumiseni], siis ei pea meie selle ala tegevuse põllul mitte tagasi põrkama." ${ }^{47}$

Maanõukogu 15. novembri otsuses kutsuda kokku Eesti Asutav Kogu oli viide Nõukogude dekreedile siiski kaudne. Märgiti üldisemalt, et see langetati "[r]ahvaste enesemääramise põhjusmõtet aluseks võttes". ${ }^{48}$ See erinevus - enesemääramine sätestatuna Nõukogude dekreedis või üldise põhimõttena - paistab ehk ebaolulisena, kuid rahvusvahelise õiguse seisukohalt oli see kaalukas. Nagu 1918. aasta alguses tõdeti, oli “õiguse pärast pääküsimus” see, kas Eestil oli õigus iseseisvusele või oli tarvis seda alles Venemaalt nõutada. ${ }^{49}$ Eesti vaatevinklist oli enamliku võimu dekreet oma selgusega mõneti isegi suurema väärtusega kui ebamäärase sisuga rahvusvaheliselt tunnustatud põhimõte. Seda võis käsitada emamaa loana temast eralduda. Kui niisugune luba või tunnustus puudus, siis võinuks väita, et kolmas riik, kes tunnustab eralduva riigi iseseisvust, sekkub emamaa siseasjadesse ja rikub nõnda rahvusvahelist õigust. Teisalt polnud 1917. aasta hilissügisel sugugi selge, kas Nõukogude valitsus oli teiste riikide, iseäranis lääne suurriikide silmis üldse võimeline astuma selliseid siduvaid samme nagu lubada Eestil Venemaast lahku lüüa. Asjale võis läheneda ka nõnda ja see kujuneski lääneliitlaste hulgas valdavaks käsitluseks -, et Venemaal puudus pärast enamlikku pööret üldse valitsus. Eesti oli justkui lahutamatult seotud riigi külge, mis ei saanudki kuni õiguspärase valitsuse moodustamiseni tunnustada temast eraldumist - ja seega ei saanud ka teised riigid, isegi, kui oleks soovinud, teda de jure tunnustada, enne kui Venemaal on võimule pääsenud mõni riigiterviku nimel kõneleda suutev organ.

Enesemääramise õiguse kui üldise, rahvusvaheliselt tunnustatud rahutingimuse eelis oli, et see tõotas Eestile pääseda tavapärase rahvusvahelise õiguse tekitatud kitsikusest. Näis, et kui iseseisvuti enesemääramise õigusele tuginedes, siis polnud emamaa luba ega tunnustust tarvis. Sellisel

$46 \quad$ Ants Piip, Tormine aasta: ülevaade Eesti välispoliitika esiajast 1917.-1918. aastal dokumentides ja mälestusis (Tartu: Akadeemilise Kooperatiivi Kirjastus, 1966), 24.

47 RA, ERA 78.1.49, 1. 67: Vanematekogu koosolek 11. novembril 1917.

48 Otsuste teksti vt Piip, Tormine aasta, 25.

49 "Milline on meie vahekord Venemaaga?", Uus Postimees, 03.01.1918; tsiteeritud: Piip, Tormine aasta, 70. 
juhul oli Eesti diplomaatidel vaja üksnes näidata, et eestlased on rahvas, mis on loonud riigi tunnustega iseseisva poliitilise üksuse. Vähe sellest, et teistel riikidel oli õigus sellist riiki tunnustada Venemaa soovidele vaatamata - nad olid isegi kohustatud seda tegema, kui rahvaste enesemääramise õigus loeti siduvaks normiks. Usutavasti just niisugustel kaalutlustel mainiti Maanõukogu 15. novembri otsustes enesemääramise põhimõtet üldisel kujul, viiteta Nõukogude dekreetidele. Jaanuaris koostati välisriikidele märgukiri, kus täpsustati, et Maanõukogu otsused Eesti Asutava Kogu kokkukutsumise ja kõrgeima võimu kohta tehti “[v]älja minnes kõikide liitriikide poolt tunnustatud põhimõtetest [...] mida kuulutati meie maal Vene revolutsiooni järeldusena, mis annab kõikidele rahvastele õiguse oma saatust ära määrata" ${ }^{50}$ Nõnda kindlustati end õiguslikult mõlemast küljest. Tugineti Nõukogude dekreedile ja seal nimetatud enesemääramise õigusele, viimast esitati aga üldisema põhimõtte väljendusena, mis olevat rahvusvaheliselt omaks võetud.

Väide, et kõik liitlasriigid olid 1918. aasta jaanuari teiseks pooleks enesemääramise põhimõtte heaks kiitnud, oli liialdus, kuid sellel ei puudunud tõepõhi. Aastavahetusel olid nii Briti peaminister David Lloyd George kui ka Ameerika Ühendriikide president Woodrow Wilson pidanud programmilise kõne, milles selgitasid oma suhtumist Brest-Litovski rahukõnelustesse Nõukogude Venemaa ja Keskriikide vahel. Lääneliitlased ei vastanud enamlaste korduvatele kutsetele läbirääkimistest osa võtta, kuid soovisid siiski avalikult põhjendada, miks ei saadetud esindajaid kõnelustele, kus kõik pooled olid justkui väljendanud nõusolekut sõlmida "demokraatlik rahu”. Iseäranis Woodrow Wilsoni kõned tähistasid olulist etappi enesemääramise põhimõtte tõusmisel rahvusvaheliselt sissepühitsetud vormeliks. “"Enesemääramine” pole paljas sõnakõlks," ütles Wilson, "see on kohustuslik käitumisjuhis, mida riigimehed ei saa edaspidi eirata." ${ }^{51}$ Sama kinnitas Ameerika Ühendriikide Petrogradi saatkonna nõunik Jaan Poskale ja Julius Seljamaale, kui viimased tulid jaanuaris uurima Eesti iseseisvuse tagamise väljavaateid. USA esindaja meenutas Lloyd George’i ja Wilsoni kõnesid sõjasihtide kohta ning lisas (Seljamaa päevaraamatu järgi): "Iseseisvuse küsimuse otsustamisel on iseenesest mõistetav demokraatlik põhimõte rahvaste vaba enesemääramise õigusest, mille järel ka kõige väiksematel rahvastel peab õigus olema oma saatust ja riiklikku korda ning võimalikke ühendusi teiste rahvastega ise ära määrata ja otsustada." ${ }^{52}$

50 Märgukirja teksti vt Piip, Tormine aasta, 96 (tõlget veidi muudetud).

51 Woodrow Wilson, War Addresses of Woodrow Wilson (Boston, 1918), 206.

52 Julius Seljamaa, "Eesti esimesed diplomaatilised suhted suurriikidega", Iseseisvuse tuleku päivilt (Tartu: Postimees, 1923), 78. Selle kohtumise kohta vt ka Eero Medijainen, 
Iseäranis julgustavad olid vastused, mis anti märgukirjale, mille Jaan Tõnisson esitas Stockholmis Briti ja Prantsuse saatkondadele. 1. märtsil teatas Prantsuse ning 20. märtsil Briti saadik, et nende valitsus on valmis "Eesti Asutavat Kogu ajutiselt kui tegelikult iseseisvat Kogu tunnistama, kuni Rahukongress kokku astub, kes Eestimaa tulevase seisukorra rahvaste enesemääramise põhjusmõtte kohaselt ära otsustab." ${ }^{53}$ Briti välisministri Arthur James Balfouri 3. mai kiri tema vastuvõtul käinud Ants Piibule, Eduard Virgole ja Kaarel Robert Pustale oli sõnastatud ettevaatlikumalt. Maanõukogule anti tunnustus, "seniks kuni Rahukonverents kokku astub, mil Eesti tulevane riigikord, niipalju kui võimalik [as far as possible], rahva soovidele vastavalt ära korraldatakse." Briti valitsus lubas teha kõik, mis tema võimuses, et see põhimõte leiaks rahuleppes rakendust. ${ }^{54}$ 17. mail koostatud salajases märgukirjas tõstis Balfour esile mitut asjaolu, mis soosisid Eesti tunnustamist. Ta mainis, et kuna Eestit okupeerisid Saksa väed, siis olnuks see "selge saksavastane samm, mis näitab, et Suurbritannia ei saa nõustuda Saksa kavadega Läänemerel." ${ }^{55}$ Kuid ei tunnustatud mitte Eestit kui riiki, vaid Maanõukogu kui de facto valitsevat organit (mida Maanõukogu sel hetkel muidugi ei olnud). Brittidele sobis selline ajutine lahendus suurepäraselt. Õhutati eestlaste passiivset vastupanu Saksa okupatsioonile, kuid jäeti lahtised käed, otsustamaks Eesti staatuse üle tulevasel rahukongressil. ${ }^{56}$

Eestlastele sobis teadmatus muidugi halvemini. Juuni lõpus võttis Piibu ja Virgo vastu Briti asevälisminister Robert Cecil, kes küsis, kas nad on inglise vastusega rahul. Üldiselt küll, vastasid eestlased, kuid pärisid, mida tähendab see "as far as possible". Kuni Cecil mõtiskles, meenutas Piip talle Briti esimest, märtsikuist kirja ja avaldas arvamust - või pigem lootust -, et "esimene self-determination õigus on ka siin kõiges oma täiuses meie kohta maksev, ainult conditiaalsus [sic] näib selle objektiivse realiteedi kohta, nimelt kui palju seda teised sõdijad-kongressi osanikud adopteerivad". ${ }^{57}$

\footnotetext{
"Enesemääramise udus: Eesti ja Ameerika Ühendriigid 1918-1919", Ajalooline Ajakiri, 1 (2016), 57-59.

53 Nende vastuste tekste vt Maanõukogu protokollid 1917-1919, 294.

54 Vt Piip, Tormine aasta, 253.

55 The National Archives (edaspidi TAN), CAB 24/52/89, l. 1: Balfouri märgukiri Balti provintside kohta, 17.05.1918.

56 Et de facto tunnustuse peamine siht oli vastupanu õhutamine Saksamaale, selle kohta vt märgukirja "Esthonia: Recognition of the National Council by the British Government", Papers Relating to the Foreign Relations of the United States, Volume 1: Russia, ed. by Joseph V. Fuller (Washington: United States Government Printing Office, 1931), 841-842.

$57 \quad$ RA, ERA.1624.1.102, 1. 108: Piibu päevik.
} 
Selle peale kostis Cecil, et "niipalju kui võimalik" viitab sellele, kuivõrd sõja tulemused lubavad. Ehkki sõjaõnn näis liitlastele 1918. suvest alates aina enam naeratavat, ei muutunud Briti valitsuse vastused hiljem vähem põiklevaks. 6. septembril oli Piip taas Cecili juures ja õnnitles teda liitlaste hiljutiste võitude puhul. Venemaa ja Saksamaa vahel sõlmitud BrestLitovski lisaleping oli andnud veelgi põhjust Eesti seisundi pärast muretseda. Ent Briti asevälisministril oli Piibule rahustuseks öelda vaid seda, et Eesti suveräänsus püsis tema valitsuse silmis endiselt otsustamata seisus (in pendente).${ }^{58} \mathrm{Ka}$ Balfouri nimel kinnitati Piibule, et Saksamaale ei kuulu mingeid suveräänõigusi Eesti üle ning et Suurbritanniale pole vastuvõetav ükski rahu, mis selle põhimõttega ei arvesta. Aga kuidas olid lood enesemääramise kui hoopis üldisema põhimõttega? Välisministeeriumi 10. septembri kirjas tõdeti, et Briti valitsuse arvates laieneb see Eestile sama jõuga nagu teistele riikidele. Ometi ei saavat "selle põhimõtte täpset rakendust kindlaks määrata lahus üldisest leppest Rahukonverentsil." ${ }^{59}$

Niisiis võttis Briti valitsus 1918. aastal hoiaku, mis oli kummaliselt sarnane Vene Ajutise Valitsuse seisukohaga eelmisel aastal: anti üldisi lubadusi, kõneleti rahvuste enesemääramisest, kuid rõhutati, et lõpliku otsuse Eesti saatuse üle saab langetada üksnes tulevane rahukonverents. Viimane pidi mõistagi arvestama ka Vene valitsuse soovidega. Samamoodi olid eestlased 1917. aastal ühtejärge kuulnud, et ehkki Venemaa rahvastel on õigus enesemääramisele, ei saa keegi peale tulevase Venemaa Asutava Kogu otsustada, mida see täpsemalt tähendab ja Eestile pakub. Kõigest hoolimata oldi Eestis 1918. aasta sügisel optimistlikud. Rõõmuga nenditi, et kuigi reaaljõud katsuvad uusi püüdeid alati kammitseda, ei paista sellised raskused enesemääramise põhimõtet ohustavat. "Kuigi piiratud kujul, tunnistavad teda praegu isegi suurrahvused, kes seni endid aina oma üleoleku püüetest lasksid juhtida." ${ }^{\prime 0}$ Otsekui tõenduseks ilmusid novembris ajalehtede veergudel lääneriikide valitsuste vastused Eesti diplomaatidele. Piiravad tingimused jäid tähelepanu alt välja. Välissaatkonna liikmed kuulutasid avalikult, et Inglise valitsuse kinnitusel ei saa Eestis pärast sõda maksma ükski valitsusviis, "mis mitte ei ole kokkukõlas Eesti rahva tahtmisega, ehk mis rahva enesemääramiseõigust kitsendaks." ${ }^{61}$ Kuni liitriigid selle aate eest võitlesid, pidi ka eestlaste poolehoid nende päralt olema. ${ }^{62}$

\footnotetext{
58 RA, ERA.1624.1.103, l. 16: Piibu päevik.

59 RA, ERA.4002.1.8, 1. 1: Briti välisministeeriumi kiri Ants Piibule, 10. september 1918.

60 "Enesemääramise põhjusmõte", Postimees, 16.10.1918, 1.

61 Jaan Tõnisson, Karl Menning, Mihkel Martna, Eduard Virgo, "Eesti saatkond Eesti rahvale!", Tallinna Teataja, 13.11.1918, 1.

62 "Eesti rahvusvaheline seisukoht", Tallinna Teataja, 12.11.1918, 1.
} 


\section{Pariisi pettumised}

1918. aasta novembri lõpus seadis Konstantin Päts kokku uue Ajutise Valitsuse, milles Jaan Poska sai välisministriks. Deklaratsiooni järgi võttis valitsus sihiks enesemääramise õigusele toe otsimise suurriikide hulgas, et nõnda "väljamaal, iseäranis rahukonverentsil [...] Eesti iseseisvusele rahvusvahelises elus kindla aluse panna". ${ }^{63}$ Väljavaated olid head, sest Briti valitsus oli otsustanud Eestit sõjaliselt abistada. 28. novembril teatasid välisdelegatsiooni liikmed Piip, Pusta ja Martna Londonist, et Tallinnasse on peatselt oodata liitlaste laevu. Lisaks palusid nad rahu sõlmimist ette valmistava konverentsi tarbeks erivolitusi endale ja välisministrile. ${ }^{64} \mathrm{Piibu}$ arvates oli rahukonverentsile vaja suuremat delegatsiooni, sh Poskat, "kelle osavõtmine ka tema isikliste omaduste tõttu tingimata tarviline oleks." ${ }^{35}$ Ajutine Valitsus oletas, et erivolitustega delegatsiooni ei vajata mitte tunnustuse saamiseks, vaid mingite lepingute sõlmimiseks. ${ }^{66}$ Seega paistis, et lõpliku de jure tunnustuse andmise on liitlased juba otsustanud.

Järgnenud Pariisi rahukonverentsi on Tartu rahu kontekstis valdavalt kujutatud Jaan Poska pettumise ja silmade avanemise loona. Eduard Laamani sõnul lähenes Poska oma ülesandele alguses juristina. "Ta toetus rahvaste enesemääramisõigusele, mida liitriigid olid kuulutanud, eriti lubadustele, mis nad 1918. a. Eestile olid andnud." ${ }^{67}$ Tartu rahule pühendatud monograafias möönis ajaloolane Edgar Mattisen, et "[t]eatav alus ju lootuste hellitamiseks oli", kirjeldamaks seejärel, kuidas "nõiaring" Eesti staatuse ümber juuli lõpuks tasapisi sulgus. ${ }^{68}$ Pole tõesti kahtlust, et Poska päevaraamat kajastab "suurepäraselt kõike seda negatiivset, mida tal suurriikide poliitikaga tutvudes kogeda tuli", kui kasutada Heino Arumäe sõnu. ${ }^{69}$ Juba veebruaris, kui Pariisis oli veedetud vaevalt kuu, kirjutas Poska, et suurriigid ei raja sugugi oma tegevust avalikult kuulutatud hüüdsõnadele. "Kõik need põhimõtted on ainult lipp, mida väga osavasti tarvitatakse oma tõsiste püüete varjamiseks." ${ }^{" 70}$ Möödus veel kuu ja Poska

\footnotetext{
63 Ajutise Valitsuse deklaratsioon, Riigi Teataja, 3, 30.11.1918, 9.

64 "Piibu, Pusta ja Martna telegramm Londonist Tallinnasse, 28.11.1919", Piip, Tormine aasta, 349-350.

65 RA, ERA.1624.1.103, 1. 27: Piibu märkused osavõtu kohta tulevasest rahukonverentsist, 3. oktoober 1918.

66 Poska kõne Asutavas Kogus, 25.04.1919, vt Asutava Kogu I istungjärk (Tallinn: Täht, 1919), v 82-83.

67 Laaman, Jaan Poska, 107.

68 Mattisen, Tartu rahu, 142, 151.

69 Arumäe, "Jaan Poska tee Tartu läbirääkimisteni”, 366.

70 Jaan Poska Eesti iseseisvuse võitluses kõige põnevamal ajajärgul: J. Poska päevaraamat rahukonverentsilt (Tallinn: Vaba Maa, 1921), 16.
} 
nägi maksmas ainult rusikavõimu ja omakasu. "Mina usun kindlasti, et "rahvaste enesemääramise õigusest" rahukongressil enam ei räägita või kui seda tehakse, siis ainult pilkavalt." ${ }^{\prime 1}$ Kui neid märkusi vaadelda teetähistena, siis sugeneb mulje, et 1919. aasta kevadel välisdelegatsiooni esimehes juba küpses suvine meelemuutus rahu kasuks enamlastega - ning et kõige põhjuseks oli suurriikide silmakirjalikkus.

Ometi tekitab suuri kõhklusi Poska vastandus ühelt poolt enesemääramise õiguse ja teiselt poolt rusikavõimu ja omakasu vahel. Eestlastele võisid asjad Pariisis ehk tõesti nii vastuokslikult paista. Ent suuriigid hindasid enesemääramise põhimõtet algusest peale vastavalt sellele, kas see suudab luua rahvusvahelist korda, vältida pingeid ja sõdu. 1917. aasta jaanuari lõpus, veel enne, kui Ameerika Ühendriigid Keskriikidele sõja kuulutasid, märkis Woodrow Wilson senatis peetud kõnes: "Ükski rahu ei saa ega tohiks kesta, kui ei tunnusta ega võta omaks põhimõtet, et valitsejad ammutavad kogu oma õiguspärase võimu valitsetavate nõusolekust, ning et kellelgi pole õigust anda rahvaid ühe valitseja alt teise alla, nagu oleks tegemist omandiga." ${ }^{\text {22 }}$ Mõte oli, et rahu kestab juhul, kui see on õiglane sama mainis Ants Piip hiljem Tartu rahulepingu kiituseks. Kuna eeldati, et õiglust väljendab just elanikkonna võimalus enesemääramiseks, siis jäi lahtiseks küsimus, mida teha siis, kui tuleb valida enesemääramise ja rahu kui kahe iseseisva väärtuse vahel. Kui ütleme, et sellises olukorras tähendab esimese ohverdamine teise kasuks rusikapoliitikat, siis taandame kogu rahutegemise raskuse lihtsustavaks vastanduseks õiguse ja jõu, ideaalide ja reaalpoliitika vahel.

Hoopis varjundirikkama pildi rahu tagamise probleemidest andis 1916. aasta septembris Briti sõjakabineti tarbeks koostatud salajane märgukiri. Selles alustati tõdemusest, et Suurbritannia oli kuulutanud peamise sõjasihina kindlustamist, et kõik Euroopa riigid, nii suured kui ka väikesed, saaks areneda vabalt ja ohustamata. Lisaks olevat selge, et "meie riigile ei ole vastuvõetav ükski rahu, mis ei tõota kujuneda püsivaks, ning peamine tingimus selliseks rahuks on, et rahvuste soovid rahuldataks suurimal võimalikul määral. Rahvuspõhimõte peab seega olema üks põhiteguritest, kui kaalutakse sõjajärgseid territoriaalseid korraldusi." Otsekui polekski erinevate eesmärkide vahel vastuolu, lisati märgukirjas, et "seega ei tohi ühelegi riigile panna raskeid majanduslikke kitsendusi, nagu näiteks jätta ta ilma kaubanduskanalitest, kuna selliste võimaluste puudumine mõjutaks tingimata iga rahuleppe püsivust." Need tingimused ähvardasid

\footnotetext{
$71 \quad$ Ibid., 42.

72 Wilson, War Addresses, 8.
} 
tekitada küllalt peavalu. Ent märgukirjas lisati, et arvestada tuleb ka liitlastele antud lubadusi ja hoiduda ühegi riigi paisutamist rahvuspõhimõtte nimel nii suureks, et ohtu satuks Euroopa rahu. ${ }^{73}$

Mõistagi ei unustanud lääneriikide valitsused ja diplomaadid Pariisis oma (mh majanduslikke) erihuve. Sellest annab aimu asevälisminister Cecili 1918. aasta sügisel koostatud märgukiri. Cecil kirjutas, et mõtleb hirmuga väikeste Balti riikide saatuse peale, keda ähvardab enamlik korralagedus ja hävitustöö. Otsustav polnud aga mitte niivõrd küsimus, kas korralagedus ja hävitustöö hoitakse ära, vaid kes selle ära hoiab: kas Saksamaa või Suurbritannia. Kui Saksamaa, siis läheks Läänemeri tema valdusse. Sakslased valitseksid siis endise Venemaa alasid kui mitte poliitiliselt, siis vähemalt kaubanduslikult. Briti poliitika eesmärk oli tagada, et rahu sõlmimise järel oleks neis piirkondades, "kus praegu on korrapärane elu ja sõbralik elanikkond, võimalikult hea ja püsiv valitsemisvorm" ${ }^{74}$ Seda nõudsid Briti majandushuvid. Oleks siiski kummaline arvata, et rahu säilitamine polnud samuti liitlaste huvides, seda enam, et sõda oli neelanud määratuid summasid. Ja kui Eesti iseseisvus selles üldisemas rehkenduses lääneliitlaste silmis esialgu peale ei jäänud, siis ei luba see tõsiasi veel öelda, et enesemääramise paleus allutati rusikapoliitikale. Nagu Georges Clemenceau nelja liitlasriigi kõnelustel - heas usus või mitte - täheldas, tuli selleks, et enesemääramise põhimõtet kaitsta, tunnistada sellega möödapääsmatult kaasnevaid raskusi. ${ }^{75}$

Hea näite selliste raskuste kohta pakub arutelu Fiume rannikulinna üle, mida Itaalia nõudis endale põhjendusega, et linna elanikud olid teostanud oma õigust enesemääramisele. Wilson esitas selle nõudmise vastu erinevat laadi argumente. Kuni Dalmaatsia rannik kuulus Austria-Ungarile, soosisid strateegilised kaalutlused tema sõnul Itaalia nõudmisi. Fiume pakkuvat Itaaliale sellises olukorras kaitset. Tulevikus minevat aga rannik teiste riikide valdusse. Seega tuli valida mitme riigi nõudmiste vahel, mis võisid kõik tugineda enesemääramise õigusele. Wilsoni sõnul oli ta seotud põhimõtetega, millest oli seni juhindunud. "Meie seisukohalt pole siin asi omahuvis. Asi on rahvaste õiguses enesemääramisele ja maailma õiguses kindlale ja püsivale rahule." ${ }^{76}$ Kui rahu tagamist pidada Ameerika

73 TAN, CAB 24/2/32, l. 1: Ettepanekud tulevase territoriaalse korralduse aluste kohta, september 1916.

74 TAN, CAB 24/67/50: Robert Cecili märgukiri Venemaa-poliitika kohta, 20.10.1918.

75 "Nelja liitlasriigi kõneluste protokoll, 27.03.1919", The Deliberations of the Council of Four (March 24-June 28, 1919) (Princeton University Press, 1992), 34.

76 "Nelja liitlasriigi kõneluste protokoll, 21.04.1919", The Deliberations of the Council of Four (March 24-June 28, 1919), 308. 
Ühendriikide erihuviks, siis pandi viimane siin tõesti maksma. Kuid oleks veider väita, et tegu oli enesemääramise põhimõtte küünilise manipuleerimisega. ${ }^{77}$ Pigem oldi siin silmitsi kaht laadi raskusega. Esiteks ei kirjutanud see põhimõte ette ainuvõimalikke lahendusi. Isegi juhul, kui mõni asjatundja oleks katsunud Pariisi rahukonverentsil enesemääramise õigust suurima võimaliku idealismiga ellu rakendada, ei oleks ta pääsenud valusatest valikutest. Teist laadi raskus johtus vajadusest arvestada mitte ainult enesemääramise kui väärtusega, vaid kõigega, mis mõjutas rahu püsimist. Eesmärkide lahknemise võimalus toodi teravalt Wilsoni ette, kui arutlusele tuli rahuleppe kava punkt, mis keelas Austrial ühineda Saksamaaga. Wilson väljendas kahtlust, kas nõnda ei riivata austerlaste õigust enesemääramisele. Lloyd George esitas seepeale küsimuse: "Kujutlegem, et on olemas iseseisev Reinimaa ja me leiame, et selle jäädav eraldamine Saksamaast on vältimatult vajalik Euroopa julgeolekuks. Miks mitte seda nõuda?” Wilson vastas resoluutselt: "Ma ei saa seda põhimõtet omaks tunnistada. Ma jään selle juurde, et tuleb tagada enesemääramise õigus." ${ }^{\prime 8}$

Selles arutelus põrkusid paleused ja pragmaatika ainult näiliselt. Õigus rahule, mida Wilson enesemääramise kõrval mainis, oli samuti paleus ja sugugi mitte väikese kaaluga. Rahu kui väärtus nõudis aga pragmaatilist vaadet maa-alade sõjalisele kaitstavusele, kaubandusele, mõjupiirkondadele, võimalikele pettumustele, mida iga territoriaalne jaotus ähvardas kaasa tuua ning millest võis karta tulevasi pingeid. Kui need, kellel lasus sõjaohu kõrvaldamise vastutus, poleks kõigele sellele tähelepanu pööranud, siis vääriks nende tegevus hukkamõistu. Nõnda ei saa me seda käsitada laiduväärse omakasupoliitikana, kui Prantsusmaa allutas Venemaa pinnal tekkinud uute riikide probleemi julgeolekukaalutlustele. Eestlastele ei valmistanud see mõistagi rõõmu, kui nad Clemenceau'lt otsesõnu pärisid, kas nende iseseisvust toetatakse, ja nägid, kuidas "[v]ana rebane püüdis [...] igat viisi meile vastust võlgu jääda" ${ }^{79}$ Wilsoni juurde ei pääsetud isegi jutule. Poska järeldas sellest, et "kui kord võimumehed omale jõu ja kasu on juhtnööriks võtnud, siis vaja nende tulusid silmas pidades neile katsuda selgeks teha, et neile kasulikum on, kui meid Venemaast lahutatakse." ${ }^{\prime 0}$

\footnotetext{
77 Seda on väidetud ka Wilsoni suhtumise kohta Fiume staatusesse, vt Sterling J. Kernek, "Woodrow Wilson and National Self-Determination along Italy's Frontier: A Study of the Manipulation of Principles in the Pursuit of Political Interests", Proceedings of the Americal Philosophical Society, 126 (1982), 268.

78 Nelja liitlasriigi kõneluste protokoll, 02.05.1919, The Deliberations of the Council of Four, 459.

79 Poska, Päevaraamat, 43.

$80 \quad$ Ibid., 44.
} 
Seda oligi tarvis teha. Ent peamine oli näidata, et Eesti ja teiste Balti riikide iseseisvus soosib rahu - mida oli pea võimatu teha olukorras, kus vähemalt Prantsusmaa juhid pidasid Euroopa ja iseenda julgeoleku möödapääsmatuks tagatiseks Venemaa säilitamist ja tugevdamist liitlasena. Külma ja tasakaaluka ilmega Poskat ajas selline suhtumine puhuti ahastusse. Välisdelegatsiooni märtsikuisel koosolekul avaldas ta arvamust, et "Prantsusmaa ei taha meie iseseisvust ja näeks hea meelega, et enamlased meid ära võtaksid." ${ }^{81}$

Prantsusmaa valitsuse kavades oli Eesti tõesti kõrvaline muutuja, kuid see ei olnud iseenesest veel takistus iseseisvusele. Mai alguses tutvustas Clemenceau nn suure neliku kõnelustel oma mõtteid Saksamaaga sõlmitava rahulepingu artikli kohta, mis puudutas Venemaad. Tema sõnul oli eesmärk takistada viimase koloniseerimist Saksamaa poolt. Vahend selle vältimiseks oli sakslastele pandav kohustus tunnustada riike, mis olid kuulunud endisesse tsaaririiki, koos nõusolekuga, et Venemaale jääb restitutsiooniõigus. "Me ei saa lubada, et sakslased hakkavad Venemaad valitsema ja saavad nõnda kõige võimsamaks jõuks Euroopas." ${ }^{82}$ Siin peitus eestlastele oht, aga ka võimalus. Prantsusmaa eelistas, et Saksamaale kujuneb vastukaaluks Venemaa, mille valitsus, nagu Lloyd George märkis, "tõukub sõbralikest soovidest". ${ }^{33}$ Peljati, et kui tulevasele Venemaale valmistatakse tema osade ära murdmisega kibedust, siis võib see hakata lähenema Saksamaale. Et Saksa idakolonisatsiooni oht oli olemas ka enamlaste võimutsedes, kinnitas kujukalt Brest-Litovski lepe. Eestlaste võimalus seisis selles, et ehkki prantslaste esimene plaan jättis Eesti Venemaa rüppe, lubas varuplaan, millele mõeldi alles visandamisi, talle enamlaste ja Saksamaa vahelise kiilu rolli. Oli sel midagi pistmist enesemääramisega? Kui viimases näha ettekirjutust, et iga rahvas peab soovi korral tingimata saama iseseisva riigi, siis mitte. Kuid see polnud ainuvõimalik tõlgendus. Henry Franklin-Bouillon, Prantsuse Senati väliskomisjoni esimees lootis eestlastele pakkuda seda, mida Poska ise oli vähem kui kaks aastat tagasi kirjeldanud enesemääramise õiguse teostusena - osariiklust Venemaa föderatsioonis. 1919. aasta märtsi lõpus arvustas Franklin-Bouillon saadikutekojas oma valitsust, kes olevat Eesti ja teised väikeriigid jätnud liitlaste abita. Et enamlusele tammi

$81 \quad$ RA, ERA.1619.1.3, 1. 108: Välisdelegatsiooni koosoleku protokoll, 31. märts 1919.

82 "Nelja liitlasriigi kõneluste protokoll, 02.05.1919", The Deliberations of the Council of Four, 459.

83 Ibid. 
ette tõmmata, tuli tema sõnul viibimata toetada riike, mis "Wilsoni põhimõtete järgi" olid Venemaa varemetele tekkinud. ${ }^{84}$

Poska meelest oli selline poolik vastutulek näide suurriigi ja väikeriigi suutmatusest teineteist mõista. "Suure rahva esitaja seletab väikse rahva omale kõige magusamal toonil, kui soojalt tema rahvaste enesemääramise õiguse peale mõtleb, kui sügavasti tema selle teostamist ihaldaks, aga mureliku näoga lisab ta juure: väiksel rahval on võimata iseseisvat riiklist elu elada... Mine saa nüüd temast aru: väikerahvaste enesemääramise poolt, aga nende [iseseisvuse] vastu. Väikse rahva mehe mõttes: oled sa enesemääramise poolehoidja, siis ei või sa ka iseseisvuse vastane olla, aga suure rahva mehe pähe mahub see väga hästi, mispärast nad teineteisest mitte aru ei saa. ${ }^{" 85}$ Sarnastes kibedates toonides on kujutatud aprillis moodustatud Balti komisjoni ja eestlaste ettekannet selle ees mai lõpus. Eduard Laamani sõnul oli see järjekordne etapp liitlaste meeleolu tundma õppimisel ja lootuste murdumisel. ${ }^{86}$ Et pettuti, selles pole kahtlust. Oli ju Asutav Kogu, Eesti rahva demokraatlikult valitud esindus, 19. mail pöördunud rahvusvahelise avalikkuse poole seletusega iseseisvusest. Viimase koostamist olid ajendanud aprilli lõpus Tallinnasse naasnud Poska edastatud kuuldused, et Asutava Kogu vasak tiib polevatki iseseisvuse poolt. Et Eesti seisukoht väljamaal kindel oleks, pani Tõnisson ette koostada deklaratsioon, milles teatati astumisest iseseivate riikide sekka. ${ }^{87}$ "Mis õigusega astub Eesti rahvas selle otsustava sammu?" küsiti seletuses. "Selle loomuliku õigusega enesemääramise ja vaba enesevalitsemise peale, mis juurdub iga rahva elutungis... Mitte silmapilgukski ei taha ega või Eesti rahvas lubada mõtet, et see üleüldine õigus tema kohta jääks ainult sisuta sõnaks." ${ }^{88}$ Tahes-tahtmata tuli Eesti välisdelegatsioonil paar päeva hiljem aga just seda kurba mõtet vaagida. 21. mail läks Piip Balti komisjoni liikmetega kõnelema. Ta sai kokku Ameerika Ühendriikide esindaja Samuel Morisoniga. Viimane nentis hiljem, et raske oleks kujutleda veenvamat enesemääramisele tuginemist kui Eesti Asutava Kogu seletus. ${ }^{89}$ Ometi ütles Morison Piibule, et lootust tunnustamisele ei ole. "[K]as meie pettumust arvesse ei võeta?"

84 RA, ERA.957.11.124, 1. 81: Ülevaade Henry Franklin-Bouilloni esinemisest Prantsuse saadikutekojas.

85 Poska, Päevaraamat, 48.

86 Eduard Laamani ülevaade "Eesti välissaatkond ja Pariisi rahukonverents", Poska, Päevaraamat, 83 .

87 Asutava Kogu I istungjärk (Tallinn: Täht, 1919), v 98.

88 "Eesti Asutava Kogu seletus Eesti riiklisest iseseisvusest ja rippumatusest", Asutava Kogu I istungjärk, v 474.

89 Samuel E. Morison, "The Eastern Baltic”, The New Europe, 12 (1919), 203. 
päris Piip. Morison küsis vastu, kas eestlastele siis autonoomiast ei aita. Nagu Piip pärast seletas, oli kõnelus "õige äge". ${ }^{90}$

Ehkki lootused polnud kõrged, asusid välisdelegatsiooni liikmed kiires korras oma esinemist kavandama, kui neid 27. mail Balti komisjoni ette kutsuti. Piip pakkus, et võiks kõneleda laiemalt poliitikast: Venemaa tunnustamisest (kinnitada, et Eesti ei pea Koltšaki valitsusest rohkem kui mõnest teisest Vene valitsusest), Eesti ja Saksamaa vahekorrast, suhetest naabrite Läti ja Soomega. Nikolai Köstner aga arvas, et "ei peaks esialgu liig palju deklareerima, vahest ehk ainult Asutava Kogu otsust ning liidulaste lubadusi, viimaseid teatud veksliks pidades, mille väljalunastamist nõuda." ${ }^{91}$ Sellest hakkaski Piip peale, kui järgmisel päeval Prantsuse välisministeeriumi toredas Seinakella saalis komisjoni ees sõna sai. Pärast meenutamist, et eestlased olid juba kuus kuud oma demokraatlikult kuulutatud iseseisvuse eest võidelnud, lisas ta: "Meie ei kahtle, et meie iseseisvus liitlaste poolt saab tunnistatud, sest seletustega, mis meile tehtud ja kinnitustega, mis meile antud, on meie enesemääramise õigus kindlustatud." Seejärel luges Piip ette eelmisel aastal saadud "vekslid" koos katkendiga Woodrow Wilsoni kõnest, kus viimane mainis, et enesemääramine pole paljas sõna. Komisjoni esimees Esmé Howard alustas oma vastust julgustavalt. Ta lubas eestlastele, et neile antud lubadustest peetakse kinni esmalt enda ja siis ka teiste liikmete nimel, kui nägi, et need noogutavad. Kuid järgnes pettumust valmistav tingimus: küsimust ei saavat otsustada Venemaa nõusolekuta. Piip täpsustas viisakalt, et pole arvanudki, nagu ei peaks liitlased oma deklaratsioonidest kinni. "Meie tahame ainult, et meie õigused kohe tunnistataks." Näilisest üksmeelest hoolimata oli selge, et "õigustest" saadi aru erinevalt. Piip sõnas, et ei näe põhjust, miks on tarvis Venemaa heakskiitu. "Eestimaa ei tunnista enda üle ühegi Vene valitsuse võimu ega tunnista ühelgi neist õigust olevat Eestimaa eest rääkida ega nõusolekut avaldada. Meie rahvas on iseseisev meie elanikkude resoluut tahtmise järel, mis veel hiljuti avaldatud ja seepärast ei või mingit juttu olla Vene valitsuse ootamisest."

$90 \quad$ RA, ERA.1619.1.3, 1. 153: Välisdelegatsiooni koosoleku protokoll, 21. mai 1919.

91 RA, ERA.1619.1.3, 1. 160: Välisdelegatsiooni koosoleku protokoll, 27. mai 1919.

92 RA, ERA.957.11.124, 1. 176-181: Eesti saadikute esinemine Balti komisjonis, 28. mai 1919. Järgmisel päeval kohtusid Piip ja Pusta Briti esindaja James Simpsoniga, kes palus Piibul kasvõi rahvusvahelise õiguse professorina visandada teoreetiline kava mitteslaavi rahvaste hõlmamiseks Vene föderatsiooni. Piibu ettepaneku järgi tulnuks sõna "Vene" nimest välja jätta, et mitte anda ühele rahvale eelisseisundit. Föderatsiooni nimeks pakkus ta "Ida-Euroopa Ühendriigid”, vt Charlotte Alston, “The Suggested Basis for a Russian Federal Republic': Britain, Anti-Bolshevik Russia and the Border States at the Paris Peace Conference, 1919", History, 91 (2006), 33. 
Tõesti, kummaline lugu: selgel sõnal oli kuulutatud enesemääramise õigust, Eesti Asutav Kogu oli kokku tulnud, seda õigust kasutanud - ja nüüd öeldi, et Vene käest on veel tarvis luba küsida. Keskvõimu loal oleks Eesti võinud ennegi Venemaast lahku lüüa. Mida uut oli talle siis antud? Kui enesemääramist samastada iseseisvusega, nagu Poska seda 1919. aastal tegi, siis peab järeldama, et mitte midagi. Ent enesemääramist võis käsitada ka rahvusvaheliselt tagatud omavalitsusena Venemaa kooseisus. Kohe pärast seda, kui Eesti diplomaadid olid Balti komisjoni istungilt lahkunud, hakkaski viimane sellist lahendust Briti märgukirja põhjal arutama. "Esimene küsimus, mille märgukiri tõstatab, on iseseisvus," alustas Prantsusmaa esindaja Albert Kammerer. "Kas selle all tuleb mõista täielikku iseseisvust?" "Muidugi mitte," vastas esimees Howard. "Sõna "autonoomia" hõlbustaks Venemaa nõusoleku saamist, sõna "iseseisvus" rahuldaks enam eestlasi." ${ }^{93}$ Nõnda oligi mõne sõnaga kokku võetud Balti komisjoni, iseäranis Suurbritannia ees seisev dilemma. Mida rohkem anti Eestile, seda vähem võis oodata nõustumist neilt, kelles sooviti näha Venemaa valitsust. Pole põhjust arvata, et see polnudki tõeline dilemma. Esmé Howard leidis, et Balti riigid väärisid toetamist rohkemgi kui Vene valged. Peamiseks eesmärgiks seadis ta Saksamaa ja Venemaa territoriaalse lahutamise. Seda sai Howardi meelest kõige paremini saavutada nii, et kahe suure vahele luuakse väikeriikide ahel, millest mõned on iseseisvad, mõned avara autonoomiaga tulevases Vene Föderatsioonis. ${ }^{94}$ Pearõhk oli Venemaa terviklikkuse säästmisel, kuid hoolitseda tuli sellegi eest, et Venemaa ei saaks Eestile antud tagatisi "kohelda paberlipakatena". ${ }^{95}$

Juuli alguses, kui liitlased olid juba tunnustanud Koltšaki valitsust, leppisid ka eestlased ajutiselt vähemaga. Balti komisjonile saadetud kirjas palus Pusta deklareerida, et kuni Rahvasteliit pole Eesti seisundit lõplikult kindlaks määranud, on tal vähemalt täielik de facto iseseisvus: et Eestis kuulub suveräänsus rahvale, kes teostab ainuvõimu kogu Eesti alal. "Siin esitatakse meile väga vastuvõetavaid tingimusi,” tõdes Prantsuse esindaja Kammerer. ${ }^{96}$ Lahendus, mille poole komisjon tüürima hakkas, oli piiratud iseseisvus Rahvasteliidu tagatisega vabalinn Danzigi eeskujul. Viimane kujutas endast üht neist juriidilistest leiutistest, millega Pariisis üritati lepitada näiliselt lepitamatut. Wilsoni neljateistkümne punkti

\footnotetext{
93 RA, ERA.1583.2.1, l. 115-116: Balti komisjoni istungi protokoll, 28. mai 1919.

94 "Esmé Howardi märgukiri Briti välisminister Arthur Balfourile, juuni 1919", B. J. C. McKercher, Esme Howard. A Diplomatic Biography (Cambridge University Press, 1989), 214.

95 RA, ERA.1583.2.1, 1. 124: Balti komisjoni istungi protokoll, 28. mai 1919.

96 RA, ERA.1583.2.1, l. 134: Balti komisjoni istungi protokoll, 2. juuli 1919.
} 
rahukava sisaldas nõudmist luua iseseisev Poola, mis hõlmab alasid, kus elanikkond on kaheldamatult poola rahvusest ning millel on vaba ja kindel ligipääs merele. Häda oli selles, et niisugust merelepääsu sai pakkuda vaid sakslastega asustatud territooriumi arvel. Tekkis raskus, mis ilmestab hästi enesemääramise põhimõtte reaalpoliitilist sisu. See põhimõte rääkis üldisel tasandil vastu ettepanekule anda Poolale sadamalinn Danzig, mis oli suuremalt jaolt asustatud võõra rahvaga. Enesemääramise sisustamisel oli siin aga esiplaanil strateegiline kaalutlus, et tulevikus tugevnev Saksamaa hakkaks Poolale loovutatut tagasi nõudma - ning seda kindlamalt, mida enam jäetakse arvestamata rahvuspõhimõttega. Teisisõnu oli tegemist olukorraga, kus enesemääramise põhimõtte eiramine ähvardas suurendada rahvusvahelisi pingeid. Väljapääsu otsiti Danzigi saksa elanikkonna õiguste tagamisest rahvusvaheliste lepingutega. ${ }^{97}$

Mida pakkus see eeskuju Eestile? Kammereri sõnul polnud analoogia võimalik: "Neid olukordi ei saa võrrelda. Me tahtsime anda Poolale ligipääsu merele ja samal ajal tunnistada, et Danzig on saksa linn. Nõnda välistati Danzig nii Poola kui ka Saksa suveräänsuse alt ja pandi ametisse liitlaste komissarid. Eestis seda teha ei saa." ${ }^{98}$ Mõtete settimatust näitab seegi, kuidas Balti komisjon kõikus erinevate väljendite vahel, kirjeldamaks Eesti tulevast staatust: "vaba riik", "autonoomne Venemaaga ühendatud riik", "Venemaa ülemvõimu all olev riik". Peale nime tuli aga üksikasjus kõne alla ka loodava üksuse sisemise korraldus: esinduskogu võimalus võtta iseseisevalt vastu põhiseadus, diplomaatilised suhted, toll, maksud jms. Mindi nii kaugele, et taheti keelata sõjaväe värbamist Eestis, samuti Vene vägede viibimist seal rahuajal. Kõik sellised katsed Eestile mõnd püsivamat rahvusvahelist statuuti valmistada jooksid Venemaad puudutanud sündmuste mõjul liiva, nentis Eduard Laaman. "Selle statuudi lõi hiljem elu ise." "99 Laamani sõnul oli Balti komisjonil siiski see tähtsus, et avalikuks tuli liitlaste suhtumine Balti riikidesse juhul, kui Venemaal kujuneb püsiv valitsus, täpsemalt liitlaste valmisolek loovutada Venemaale täielik võim Soome lahe üle sõjaliste toetuspunktide abil mõlemal kaldal. Siin võib näha järeleandlikkust väikeriikide arvel - ja mõelda sellise

$97 \quad$ Selle lahenduseni viinud läbirääkimiste kohta vt Anna M. Cienciala, "The Battle of Danzig and the Polish Corridor at the Paris Peace Conference of 1919", The Reconstruction of Poland, 1914-23, toim Latawski (Palgrave Macmillan, 1992), 71-94; Lutz Oberdörfer, "The Danzig Question in British Foreign Policy, 1918-1920", Diplomacy and Statecraft, 15 (2004), 573-592.

$98 \quad$ RA, ERA.1583.2.1, l. 142: Balti komisjoni istungi protokoll, 4. juuli 1919.

99 Eduard Laaman, "Liitriikide kavatsusi Eesti tulevasest statuudist Vabadussõja aegu”, Sõdur, 45/46 (1930), 1300. 
suhtumise järelkajale kaks kümnendit hiljem, kui kõne alla tulid baaside lepingud Eesti ja Soomega. Ometi ei saa seda kirjeldada sõnamurdliku käitumisena, kui lääneliitlased kavatsesid 1919. aastal ohjata Saksamaad tugeva Venemaa abil. Eestile sooviti anda seisund, millest 1917. aasta esimesel poolel, kui enesemääramise loosung laiemalt õhku paisati, siinmail vaevu unistadagi söandati.

\section{Uned teed}

Seega ei saa öelda, et Suurbritannia ja Prantsusmaa jätsid lunastamata veksli korraldada Eesti seisund "niivõrd kui võimalik" kooskõlas enesemääramise põhimõttega. Tõsi küll, Eesti välisdelegatsiooni liikmete arvates oli võimalik teha palju rohkem. Nende ülesanne oli saada kätte see, mille järgi oli Pariisi tuldud. Sellest vaatevinklist polnud õigupoolest oluline, kas ja millised vekslid olid lunastatud. Oli sellest abi loota, siis tuli suurriigi esindajatele vähemalt jätta mulje, et nad olid lubanud iseseisvust. Ja selleks pidi enesemääramise põhimõtet tõlgendama võimalikult avaralt. Olles kuulnud Balti komisjonis üles võetud mõttest tagada Eestile iseseisev seisund Vene ülemvõimu (süseräniteedi) all, teatas Piip, et see pole vastuvõetav - nõudmine olla täielik iseseisvus. Delegatsioon otsustas "mingisuguseid järeleandmisi mitte teha". ${ }^{100}$ Sellise vankumatu hoiakuga läksid Piip ja Poska järgmisel päeval, 11. juunil Briti välisministri Arthur Balfouri vastuvõtule. 1918. aasta aprillis, vastselt Inglismaale jõudnuna oli Piip juba selle riigimehe ees seisnud. Siis oli Balfour küsinud: "Kas Teie tahate siis täiesti iseseisvaks, või rahuldab Teid autonoomia [?]" Piip oli tookord vastanud, et eestlastel pole Venemaa vastu midagi, kuid soovitakse saada täiesti iseseisvaks ja rippumatuks. Alles siis võivat teha otsuseid oma suhete kohta Venemaaga. "Teie olete nii väike. Teid on nii vähe, kaks miljonit." Jah, möönis Piip, kuid Eesti olevat kaubanduslikult tähtis ja suutvat püsida. Balfour saatis toona eestlased välja sõnadega, et Briti valitsus toetab enesemääramise õigust ja paneb nende soove tähele..$^{101}$

Nüüd, veidi enam kui aasta hiljem olid eestlased tulnud pigem nõudjate kui palujatena. Paistab, et eriti Poska läbematus oli suur. Kui Briti välisminister alustuseks päris, kuidas läheb eestlastel sõjaväljal, siis muutis Eesti delegatsiooni juht teemat repliigiga, et kodumaal on seisukord hea, Pariisis halb. "Mis nimelt?" küsis Balfour. "Rahukonverents ei taha meie iseseisvust tunnistada," kostis Poska. Briti välispoliitika juht sõnas, et polnud ju

\footnotetext{
$100 \quad$ RA, ERA.1619.1.3, 1. 180: Välisdelegatsiooni koosoleku protokoll, 10. juuni 1919.

101 Piip, Tormine aasta, 248-249.
} 
muudetud seda, mida lubati möödunud aasta mais, kui jutt oli autonoomiast. Kõneluse kestel liitus sellega Balti komisjoni esimees Esmé Howard. Piip ja Poska vaatasid pealt, kuidas Balfour ja Howard, kaks Briti juhtivat poliitikut-diplomaati, omavahel asja klaarisid. Esimene kinnitas, et mida lubati, seda täidetakse - teisiti polevat Suurbritannia iialgi käitunud. Aga mida siis lubati? Selgus, et autonoomia all mõistis Balfour täielikku iseseisvust, Howard omavalitsust. Kinnituseks, et millekski enamaks polnud kohustutud, tsiteeris viimane Balfouri eelmise aasta kirja ja selles sisalduvat väljendit "as far as possible". Piip täpsustas, et tema ei pidanud silmas mitte seda kirja, vaid varasemat, kus mainiti Suurbritannia mittenõustumist iga rahuleppega, mis rikub enesemääramise õigust. Howard seletas, et eestlastele ei saa anda iseseisvust ilma venelastelt luba küsimata. Seda olevat ta öelnud juba Balti komisjonis. Rahvusvahelise õiguse järgi ei saavat lahutada riigist üht osa, ilma selle riigi nõusolekuta. "Kas pole nii?" pöördus Howard ministri poole. Piibu sõnul noogutas küll "vanamees peaga[,] aga tundub[,] et ta sellest suurest tarkusest mitte just hästi aru ei saa[,] vaid ikka arvab[,] et ka ilma Veneta võiks seda küsimust äraotsustada" ${ }^{102}$

Mida Balfour ka ei mõelnud, kui suur ka polnud tema sümpaatia väikese südi Eesti vastu, Howardile ta vastu ei vaielnud. Viimane küsis lepitavalt, kas Eesti ei võiks jääda de facto iseseisvaks. Vormilist tunnustust olla väga raske saada. Eestlased tahtsid teada, kui kaua selline määramata olukord võiks kesta, ent jäid vastuseta. Nad katsusid ka teist argumenti: isegi kui iseseisvust otsesõnu ei lubatud, olla Eesti rahvas siiski tuginenud oma võitluses enesemääramise põhimõttele, usus, et see viiakse ellu, kui liidulased võidavad sõja, mida nad endi sõnul pidasid just selle põhimõtte teostamiseks. ${ }^{103}$ Poska lausus kaalukad sõnad: "Meie ei saa praegu teist poliitikat ajada kui kannatamatut, sest meie rahvas tahab kahtlemata iseseisvust ja kui meile iseseisvust liidulaste poolt ei anta, siis otsib rahvas teist teed."104 Brittidele need sõnad tajutavat mõju ei avaldanud. Poska pani tähele, et Balfourile tulid Howardi seletused ootamatuna. "Seisukord ei ole mitte kõige armsam," tõdes ta õhtul Eesti delegatsiooni koosolekul. "Nii inglased kui ameeriklased on oma seisukohti silmnähtavalt muutnud." Piip kirjeldas olukorda optimistlikumalt. Rahukonverentsilt saadud de facto tunnustus andvat siiski aega "ja meie peaksime selle aja jooksul endid niivõrd tugevasti kindlustama, et ükski hammas meile peale ei hakkaks.”105

\footnotetext{
102 RA, ERA.1624.1.7, 1. 79: Ants Piibu ülevaade kohtumisest Arthur Balfouriga.

103 Ibid., 1. 80.

104 RA, ERA.1619.1.3, l. 182: Välisdelegatsiooni koosoleku protokoll, 11. juuni 1919.

105 Ibid., 1. 183.
} 
Poskale oli muutus inglaste suhtumises pöördehetk, sest just neile oli ta algusest peale panuse teinud. Jaanuaris oli Poska oma kaaslastele välisdelegatsioonis meenutanud, et vahekorda inglastega ei tohi ära lõigata. Tulevat aru anda, "et meie ikka liitlastest ära ripume, sest meie tunnistamine või mittetunnistamine oleneb ju neist ära. Ja seda lõpu eesmärki ei tohi meie mitte silmast ära lasta." 106 Pariisis oli ta näinud, kuidas teised liitlased, esijoones prantslased oma seisukohta muutsid. Paistab, et veel aprilli lõpus arvas Poska, et Suurbritannia on päästev erand. ${ }^{107}$ Nüüd, juunis mõistis Poska - ja see valmistas talle sügava pettumuse -, et inglased ei tahagi eestlastele iseseisvust. ${ }^{108}$ Ta püüdis korraldada, et Inglise ajakirjanduses kirjutataks, "missugust rõhuvat muljet eestlaste peale avaldas teade[,] et Inglis[e] valitsus esialgu ametlikult sõna andis rahukongressil meie iseseisvuse küsimust otsustamisele võtta ja kõik teha[,] et see otsus rahva tahtmisele vastaks ning nüüd[,] kus As[utava] Kogu läbi rahva lõpulik tahtmine avalikuks [...] tuli eestlaste seljataga Eestimaa kohta Koltshakiga

$106 \quad$ RA, ERA.1619.1.3, 1. 10: Välisdelegatsiooni koosoleku protokoll, 29. jaanuar 1919.

107 Vt Poska Asutavas Kogus peetud kõne (25.04.1919), kus ta Suurbritanniat selles kontekstis korduvalt teistest liitlastest lahutab, Asutava Kogu I istungjärk.

108 Eero Medijainen on kirjutanud: "Välisminister Poska oli suurte kogemustega ja vilunud poliitik. Vaevalt lubas ta endale sellist emotsiooni nagu "sügav pettumus", ei üksikute indiviidide-poliitikute ega ühegi riigi või institutsiooni suhtes, ammugi mitte sellisest emotsioonist ajendatud otsuseid ja käitumist." (See oli kirjutatud vastuseks Kaido Jaansoni väitele, et Poska oli "sügavalt pettunud" Pariisis rahukonverentsis ja lääneriikides, vt Kaido Jaanson, "Välispoliitika”, Eesti ajalugu VI. Vabadussõjast taasiseseisvumiseni, toim Sulev Vahtre, Ago Pajur, Tõnu Tannberg (Tartu, Ilmamaa, 2005, 109).) Võib nõustuda, et Poskale ei saa omistada üldist pettumist rahukonverentsis ja lääneriikides - on ebaselge, mida see võiks üldse tähendada. Teisalt on pettumine vaevalt emotsioon, mida saab endale lubada või mitte lubada. Kuna emotsioon on psüühiline seisund, mille olemasolu on raske kindlaks teha, siis jääb iga väide selle kohta mõnevõrra spekulatiivseks. Et Poskat valdasid emotsioonid, nagu kõiki teisigi inimesi, selle kohta annavad tema päevikumärkmed ja sõnavõtud välisdelegatsiooni koosolekutel küllalt tõendust (Eduard Laaman, kes delegatsiooni koosolekutest osa võttis, mainib samuti Poska pettumist, vt "Eesti välissaatkond ja Pariisi rahukonverents", 88). Liiatigi ei ole põhjust pettumust (või lootust) kui emotsiooni vastandada analüüsile - see kaasneb ratsionaalse uskumuste ajakohastamisega. Kui Poska palus teatada, et brittide hoiak avaldas eestlastele "rõhuvat muljet", siis tundub kummaline eeldada, et talle endale oli selline mulje sootuks võoras, st et tema võttis olukorra lihtsalt teatavaks. Hiljem küsiti Poskalt, kas läbirääkimised enamlastega teda ei ärritanud. Ta vastas: "Ja kuidas veel! Sees otse kees, - aga kas ma tohtisin seda neile näidata?" (Laaman, Jaan Poska, 122) Et Poska käitumist ei juhtinud mitte ainult külm mõistus, seda kinnitab tema äraütlev vastus Pätsile, kui viimane veenis teda Ajutist Valitsust juhtima: "Ma saan aru, et meil tulevad ägedad võitlused, aga minu iseloom on niisugune, et ma seda ei saa. Kui peaks käsku andma, et korra alalhoidmiseks tuleks sõjariistu tarvitada, siis pole mul seks tahtmise kindlust." (Konstantin Päts, "Vanglilaagrist Ajutisse Valitsusse", Mälestused iseseisvuse võitluspäevilt, kd 2 (Tallinn: Vaba Maa, 1930), 12). 
kokku leppis selles mõttes[,] et rahukongressil asja ette ei võeta ja rahva poolt otsustatud iseseisvus Vene autonoomia peale vahetatakse." 109 Asi ei seisnud ainult selles, et nõustuti andma lubatust vähem. Poska sõnul ei olnud isegi rahvusvaheliselt tagatud autonoomia Eestile vastuvõetav, sest välisriigid ei hakanuks seda kaitsma. Samuel Morison, Balti komisjoni ameeriklasest liige väitis talle vestluses vastu, et ka iseseisvuse korral võib Venemaa uue riigi ära võtta. Poska aga tähendas, "et iseseisvuse korral meie suudame teisi riike majandusliselt niivõrt huvitada, et nemad oma huvide pärast meid toetama saavad." 110

Briti esindaja James Young Simpson seletas küll hiljem Poskale, et inglased aitavad eestlasi edaspidigi ja tahtvat õigupoolest neile anda iseseisvust, mida lihtsalt tähistati eksitavalt sõnaga "autonoomia", kuid paistab, et see ei vähendanud Poska tunnet, et eestlasi - ja teda isiklikult - on alt veetud. Seni valitud suund oli viinud ummikusse. Vaja oli uut lähenemist ja kedagi teist seda katsetama. 24. juunil palus Poska valitsusel end erru lasta. "Mina võtsin omal ajal [välisministri] ameti vastu lootuses Eesti iseseisvuse tunnistamiseks rahukonferentsi poolt kaasa töötada liitriikide[,] iseäranis Inglismaa toetuse peale baseerides. Praegu on liitlased[,] inglased ühes arvates[,] meie asjale teise käigu annud[,] mis meid ehk sunnib oma eesmärgi kättesaamiseks teisi teesid otsima ja selleks on uusi mehi tarvis." ${ }^{111}$ Errumineku otsus oli ajendatud kaalutlustest, mida Poska hakkas vaagima kohe pärast kohtumist Balfouriga. Uues olukorras olevat kaks teed: "kas katsuda Vene enamlastega rahu teha, või Vene revolutsionäridega püüda kokku leppida tingimisel, et nad meie iseseisvust tunnistaksid."112 Piip arvas, et üks ei välista teist ja lisas kolmanda võimalusena kokkuleppe Poolaga. "Neid teesid tuleks siis kombineerida ja see on üsna raske," arvas Poska. Tema sõnul peitus oht selles, et Eestis adutakse tunnustuse saamise lootusetust ja sõjarinne variseb kokku. ${ }^{113}$

Esmapilgul on raske näha, miks leidis Poska, et tema pole uuteks tegevussuundadeks õige inimene. Ebausutav on mõte, et ta ei sobinud enda meelest rahu tegemiseks enamlastega. Kõneles ta ju sellest, et teist inimest on vaja igaks suunamuutuseks, mitte üksnes läbirääkimisteks idas. Vahest

109 RA, ERA.31.1.152, 1. 34: Poska telegramm Pariisist Eesti välisministeeriumile, 27. juuni 1919.

110 RA, ERA.1619.1.3, 1. 174: Välisdelegatsiooni koosoleku protokoll, 6. juuni 1919. Ühe võimalusena iseseisvuse sõjaliseks tagamiseks tegi ta Suurbritannia esindaja Edward Carriga juttu Inglise mereväebaasi rajamisest Eestisse, vt RA, ERA.1619.1.3, 1. 177: Välisdelegatsiooni koosoleku protokoll, 7. juuni 1919.

111 RA, ERA.31.1.152, 1. 35: Poska telegramm Pariisist, 24. juuni 1919.

112 RA, ERA.1619.1.3, 1. 186: Välisdelegatsiooni koosoleku protokoll, 13. juuni 1919.

113 Ibid. 
tahtis Poska võtta vastutuse iseenda valitud poliitika ebaõnnestumise eest. See ei välistanud jätkamist juhul, kui talle antakse usaldus mõne teise - või isegi sama - poliitika ajamiseks. Et Poska nii mõtles, seda kinnitab tõsiasi, et paari kuu pärast katsetas ta mõlemat neist teedest, mis tema sõnul nüüd avanesid. Igatahes väärivad Poska ja Piibu arutlused juunis-juulis hoolikat tähelepanu, kui püüame mõista Eesti välispoliitikat 1919. aastal. Need heidavad valgust nii varasematele kui ka hilisematele sündmustele. Alustagem tõdemusest, et kõne all ei olnud uued eesmärgid, vaid uued teed, st uued vahendid. "Meie peame ainult uusi teesid otsima, mitte kõrvale jääma," ütles Poska 2o. juunil välisdelegatsiooni koosolekul, olles nentinud, et järeleandmisi teha ei saa, sest siis hakatakse nõudma uusi mööndusi, küll aga jäävat võimalus hilisemateks kokkulepeteks liitlastega. ${ }^{114} \mathrm{Ka}$ Piip väljendas muutunud hinnangut just abinõude kohta: "Senine politik on ju meil olnud puhas talupojalik ja sellepärast on neil väga lihtne olnud meiega mängida."115 Suvistes märkustes nimetas ta kevadel hellitatud tunnustamislootusi romantiliseks usuks "paberilipakate ja suurte meeste sõnade kõikumatuse peale". Asemele olevat astunud otsus "võidelda ise, kuni meie rahva õiguseni ise oma saatust määrata, ja kui vaja, otsida uusi teesi, mis nad ka ei oleks esimesel pilgul, kui nad meid aga sihile viivad". ${ }^{116}$

Ent mis siis oli see eesmärk, mille saavutamiseks otsiti uusi vahendeid? Piip võttis selle kokku sõnadega "meie vabadust kindlustada praegu ja tulevikus, meie sotsialseid reformisi teostada ilma võera pressita ja ilma nende moonutamiseta." ${ }^{117}$ Juunis oli selgunud, et Eesti suveräänsus oli liitlaste silmis endiselt kõikuvas olekus - in pendente - ja tõotas selliseks jääda mõneks ajaks. Välisdelegatsioonis anti endale aru, et niisuguses olukorras polnud Pariisis suuremat teha. "Nähtavasti ei ole nüid enam siin midagi loota, sest meie asjus oodatakse Venemaa sündmusi," tõdes Piip 9. juulil. ${ }^{118} \mathrm{Nagu}$ nägime, tuli tema sõnul juriidiliselt määramata aega tarvitada selleks, et muuta Eesti iseseisvus nii kindlaks, et ükski hammas peale ei hakka. Piibu veendumuse järgi oli tarvis noores riigis teostada radikaalsete uuenduste programm, iseäranis maareform, mis võtaks enamluselt Eestis toetuspinna. ${ }^{119}$ Rahu oli selleks kui mitte hädavajalik, siis ikkagi lihtsustav tingimus. Pole põhjust arvata, et Poska sai iseseisvuse kindlustamisest kui pakilisest ülesandest aru täpselt samamoodi. Näib, et rahvusvahelise tunnustuse

\footnotetext{
114 RA, ERA.1619.1.3, 1. 199: Välisdelegatsiooni koosoleku protokoll, 20. juuni 1919.

115 Ibid.

116 RA, ERA.957.11.26, 1. 176: Piibu memorandum Eesti ja liitlaste vahekorrast.

117 Ibid.

118 RA, ERA.1619.1.3, 1. 210: Välisdelegatsiooni koosoleku protokoll, 9. juuli 1919.

119 Vt RA, ERA.1624.1.99, 1. 41: Piibu kiri nimetamata adressaadile, 14. mai 1919.
} 
saamisel oli tema silmis endiselt väga suur kaal. Lõppude lõpuks polnud Pariisis juhtunud midagi, mis pidanuks kõigutama Eesti diplomaatide veendumust, et nende pingutuste lõppsiht on de jure tunnustus. Liiatigi ei saanud viimases näha seda sorti õiguslikku akti, mis on vähem tegelik, vähem praktiliselt mõjukas kui rahu või ühiskondlikud reformid. Pariisis kuuldi ühtejärge, kuidas Eestile ei tahetud laenata, saata sõjavarustust ega toitu põhjendusega, et riigi õiguslik seisund püsib ebakindlana. Riigi tegeliku seisundi tugevdamine veennuks ehk liitlasi, et Eesti suudab püsida oma jõududega ja seega väärib õigust enesemääramisele. Selles mõttes oli see abinõu tunnustuse saamiseks. Teisalt oli tunnustus ise tõhus abinõu, kindlustamaks, et iseseisvus jääb kestma.

Nõnda oleks ekslik väita, et 1919. aasta suvel võtsid Eesti diplomaadid kursi rahvusvahelise tunnustuse asemel rahule. Tõsi, tärkas küsimus "aktivse tegevuse kohta" ida suunal. ${ }^{120}$ Piibu hilisemate mälestuste järgi lahkus Poska Pariisist kindla otsusega alustada esimesel võimalusel rahuläbirääkimisi Venemaaga. ${ }^{121}$ Kõik viitab siiski sellele, et Poska ei käsitanud neid läbirääkimisi pea lõpuni mitte teena rahulepingu poole enamlastega, vaid abinõuna mõne teise sihi saavutamiseks: Balti liidu moodustamiseks, tunnustuse saamiseks liitlastelt vms. Seepärast saabki 1919. aasta suvel toimunud poliitikakurvi ainult tinglikult kujutada strateegilise pöördena. Hoolimata sellest, mida öeldi oma varasema naiivsuse kohta, oli aasta algusest mõeldud mitmesuguste argumentide ja sammude peale, millega tuua liitlaste silme ette kas mõni Eesti tunnustamisega seotud kasu või mõni viivitamisest johtuv kahju. Puhuti oli mindud lausa ähvardamise äärele. Jaanuaris pakkus Poska, et võiks näidata Eesti tunnustamise seost rahuga Venemaal, millega äratataks ilmselt huvi, "sest siis saaks Amerika rutem oma kaupasid Vene turule saata." ${ }^{22}$ Seletati, et iseseisvad väikeriigid takistaks Saksamaal ja Venemaal ühinemast. ${ }^{123}$ Veebruaris saatis Päts Poskale kirja, kus mainis võimalust, et Eesti ja Soome sõjaväed võtavad ära Petrogradi. See võinuks olla tasu tunnustuse eest. ${ }^{124}$ Petrogradi hooba tarvitati hiljem liitlaste juures ka sel moel, et kõneldi selle operatsiooni takistamisest. Pärast käiku Balti komisjoni jagas Piip oma muljet, "et tähtsamaks argumendiks meie iseseisvuse tunnustamise saavutamiseks ja ülevenemaalise valitsuse hädaohu vastu jääb ähvardus meie poolt

\footnotetext{
$120 \quad$ RA, ERA.1619.1.3, 1. 210: Välisdelegatsiooni koosoleku protokoll, 9. juuli 1919.

121 Piip, Tartu rahu, 355.

122 RA, ERA.1619.1.3, 1. 9: Välisdelegatsiooni koosoleku protokoll, 29. jaanuar 1919.

123 RA, ERA.1619.1.3, 1. 15: Välisdelegatsiooni koosoleku protokoll, dateerimata.

124 "Konstantin Pätsi kiri Jaan Poskale, 20. veebruar 1919", Heino Arumäe, "Kaks Konstantin Pätsi kirja Vabadussõja päevilt”, Tuna, 1 (2010), 96.
} 
fronti seisma panna[,] mida ka eila tarvitasime." ${ }^{25}$ Sama mõte oli õhus ka siis, kui Poska ütles juunis Balfourile, et kui liitlased tunnustust ei anna, siis otsib eesti rahvas teist teed.

Teiste teede otsimist sai seega käsitada mitmeti. Selles võis näha tunnustuse hankimise poliitika jätkamist uute hoobade abil. Kui oleks suudetud näidata, et ähvardus front seisma panna on tõsine, siis oleks oodatavalt avaldatud mõju nii Vene valgetele kui ka liitlastele. Sellisele kaalutlusele osutab ilmekalt Eesti välisdelegatsiooni 19. juuni kiri rahukonverentsi esimehele Clemenceau'le. Kirjas täheldati, et kui liitlased toetavad Eesti iseseisvust eitavaid Vene jõudusid, siis tekib eestlastel küsimus, kas nende sõjaohvrid on ikka vajalikud või oleks eelistatavam "käia teist teed, kaitsmaks Eesti rahva õigusi ja saavutada oma iseseisvuse tunnustamine." Olevat raske öelda, millise suuna eestlaste poliitika võtab, kuid tulevat märkida, "et selle poliitikaga olevat imperialistlikul Venemaal enam kaotada kui võita."126 Ähvardavaid vihjeid pilluti hiljemgi. Augustis, kui Peterburi-operatsioon taas päevakorrale tuli, kõnelesid eestlasedki jälle võimalusest rinne enda poolt seisma panna. Vestluses Balti komisjoni liikme Kammereriga esitas Piip lugu leebemalt, märkides, et rahvusvaheline tunnustus aitaks tõsta Eesti sõjajõudu. Kammerer ei võtnud vedu. Ta kõneles vastuseks Soomest, kes olevat samasuguste tingimistega palju kaotanud ja keda liitlased enam ei toetavat. Piip sai sellest aru nii, et enam ei tasu kaubelda, ja vaikis. ${ }^{127}$ On jõutud surnud punkti, teatas ta augusti lõpus Tallinnasse. Piibu sõnul olid nüüd "kõik teed lubatud", kindlustamaks, et Venemaa Eestit enam ei ohusta. ${ }^{128}$ Läänesuunalise diplomaatia jõudmisest surnud punkti sai aga samuti teha kaks üsna erinevat järeldust. Võis mõelda nii, et nüüd tuleb tegutseda omatahtsi ja teha enamlastega rahu. Varasema poliitikaga hoopis enam kooskõlas olnuks aga kava tõugata rahuläbirääkimiste abil tagant Vene valgeid ja liitlasi, kes tõrkusid Eestit tunnustamast.

Erinevate tõlgenduste esiletoomine ei ole pelgalt huvitav mõtteharjutus, vaid vältimatu, selgitamaks, et Eesti diplomaatide, iseäranis Piibu ja Poska vahel ei tarvitsenud olla üksmeelt selle kohta, mida tähendasid "uued teed". Ongi põhjust arvata, et kuigi mõlemad rääkisid 1919. aasta suvel rahu tegemisest enamlastega, hakkasid nad tegutsema erinevas sihis (nagu allpool

\footnotetext{
$125 \quad$ RA, ERA.31.1.152, 1. 23: Piibu telegramm Pariisist, 30. mai 1919.

126 RA, ERA.957.11.124, 1. 190: Eesti delegatsiooni kiri Rahukonverentsi esimehele, 19. juuni 1919.

127 RA, ERA.1624.1.7, 1. 103: Piibu telegramm Poskale, 19. august 1919.

128 RA, ERA.1624.1.7, 1. 122: Piibu kiri Poskale, 31. august 1919.
} 
täpsemalt näidatakse). ${ }^{129}$ Ühega olid Piip ja Poska siiski mõlemad nõus: tuli vältida, et enamlased Eesti sõjaliselt vallutavad. Sel juhul oleks tunnustus vähe aidanud. Mai keskel oli Piip kirjutanud, et on olukord, "mil puhul meie rahu peame tegema, ka oma liidulaste selge nõusolemiseta, kuid meile mõista antud arusaamisega, et teisiti võimata teha: kui meil sõja edasijätkamine enamlust maal jalule aitaks ehk jälle frondi kokkulangemist karta." ${ }^{\prime 30}$ Ka Poska kõneles ohust, et liitlastelt tunnustuse saamise väljavaate kadumisel murdub Eesti sõjaväe kaitsetahe. Päts oli talle kinnitanud: "kui see lootus langeb, et meie iseseisvus meie vastupidamise tasu on, siis langeb kohe ka meie väerind kokku." ${ }^{131}$ Seda ohtu oli Poska ise tajunud kevadisel koduskäigul. Kuna augustis tunnustust ikka ei paistnud, siis polnud oht kadunud, pigem suurenenud. Ent seegi ei tähendanud rahu tegemise möödapääsmatust. Otsus oli endiselt raske. Kas rahuleping enamlastega ei võinud Eesti julgeolekut hoopis nõrgestada? Alles mais olid britid mõista andnud, et selline lepe tooks kaasa sõjavarustuse saatmise lõpetamise ja vahest isegi sanktsioonid. ${ }^{132}$ Eestis sai Poska kuulda sõjaväe juhtide Johan Laidoneri ja Jaan Sootsi skeptilisi seisukohti. Laidoner küsis, mis tagab, et enamlased uuesti sõdima ei hakka, kui nendega leping tehakse. Nõukogude vabariik ei olevat "ühtegi rahvusvah[elist] lepingut pidanud, vaid muudab ja lõpetab neid sel ajal, kui see enaml[ikule] val[itsuse]le kasulik on."133

\section{Enamlaste tee Pihkvasse}

Oli tõesti vähe märke, nagu võinuks enamlased oma lubadustest rohkem kinni pidada kui 1917. aastal, mil Eesti eraldumisele vastati kõigist dekreetidest ja loosungitest hoolimata vägivallaga. ${ }^{134} 13$. novembril 1918, kohe

\footnotetext{
129 Ei saa nõustuda Heino Arumäega, kelle väitel pidas Poska "uute teede" all "silmas kõigepealt rahu sõlmimist Venemaaga." (Vt Arumäe, "Kaks Konstantin Pätsi kirja Vabadussõja päevilt", 92) Esiteks pidas Poska 1919. aasta suvel abinõuna silmas pigem rahuläbirääkimisi, mitte rahu sõlmimist; lisaks nimetas ta uute teede hulgas teistki abinõu - tunnustuse nõutamist mõnelt teiselt Vene valitsuselt. Niisiis arvestas Poska jätkuvalt mitmesuguste abinõudega, mis lubab arvata, et tal oli neid mõttes rohkemgi kui kaks.

130 RA, ERA.1624.1.103, 1. 61: Piibu märkmed, mai keskpaik.

131 Konstantin Pätsi kiri Jaan Poskale, dateerimata, avaldatud: Arumäe, "Kaks Konstantin Pätsi kirja Vabadussõja päevilt”, 97.

132 RA, ERA.1624.1.7, 1. 66: Piibu kiri Poskale, 6. mai 1919.

133 RA, ERA.827.1.24, 1. 74: Ärakiri Johan Laidoneri päevakäsust, 23. juuli 1919.

134 Õiguslikult tuleb eraldumisena käsitada juba 28. novembri otsuseid. Need ei välistanud küll osariiklust Venemaa Föderatsioonis, kuid tegid siiski Eestist suveräänse riigi, mis olnuks ka föderatsiooni astumise korral selle hetkeni - siseriiklikust vaatenurgast hinnates - iseseisev.
} 
pärast vaherahu allakirjutamist Saksamaa ja Entente’i vahel, tühistas Ülevenemaaline Kesktäitevkomitee Bresti rahulepingu. Selle pidavat asendama sotsialistlik rahu kooskõlas põhimõtetega, "mida oktoobrirevolutsioon üles seadis ja Vene saatkond Brestis kaitses." ${ }^{35}$ Nende põhimõtete hulgas oli mäletatavasti rahvaste õigus enesemääramisele kuni eraldumise ja iseseisva riigi moodustamiseni. Aga mida lubati nüüd Saksamaa okupatsiooni alt vabanevatele aladele? "Kõikide rahvaste töörahvakihtide enesemääramise õigust tunnistatakse täiel määral."136 Tegudes tähendas see seda, et ellu kutsuti sotsialistlik nõukogude vabariik nimega Eesti Töörahva Kommuun. ${ }^{137}$

Kommuuni nõukogu kuulutas novembri lõpus tervele ilmale, et vägede sissevalgumine idast pole mitte Venemaa rünnak (millena see kangesti välja nägi), vaid proletaarne revolutsioon. Eesti Ajutine Valitsus levitavat teateid, nagu oleks Venemaa Eesti ära okupeerinud ja rikuks eestlaste õigust enesemääramisele. "Ärge uskuge seda," hüüti Kommuuni nimel. ${ }^{138}$ Lenin võttis sündmused siiski suure selgusega kokku, kui telegrafeeris punavägede ülemjuhatajale: "Koos meie vägede edasiliikumisega läände ja Ukrainasse luuakse ajutisi nõukogude piirkonnavalitsusi, kelle ülesandeks on kindlustada nõukogusid kohtadel. Sellel asjaolul on see hea külg, et ta võtab Ukraina, Leedu, Läti, Eesti šovinistidelt võimaluse tõlgitseda meie vägede liikumist kui okupatsiooni ja loob soodsa õhkkonna meie vägede edasiliikumiseks." 139

Pidi olema raske otsustada, mis õigustas suuremat umbusku enamlaste vastu: kas see, et oli asutud varjamata mahitama üleilmset revolutsiooni ja saadetud punaväed naaberriikidesse, või see, et värsked rahulepingud sel viisil üles öeldi. Röövellikuks ja pealesunnituks tembeldati Bresti leping, mille Nõukogude valitsus oli sõlminud pärast pikki läbirääkimisi. Tühistati ka augustis Berliinis sõlmitud lisaleping, mis polnud kolme kuudki vana. Eesti vaatevinklist vääris tähelepanu eriti viimane, kuna selles võinuks näha visandit tulevaseks rahulepinguks Venemaaga. Bresti lisalepinguga

\footnotetext{
135 "Ülevenemaalise Kesktäitevkomitee otsus Bresti rahulepingu annulleerimise kohta”, Eesti Töörahva Kommuun, Dokumentide ja materjalide kogumik (Tallinn: Eesti riiklik kirjastus, 1958), 19.

136 Ibid. (rõhutus lisatud).

137 Sellise moodustise põhiseadus oli välja töötatud juba 1918. aasta alguses, vt Edasi, 23.01.1918, 2.

138 "Eesti Töörahva Kommuuni Nõukogu raadioüleskutse kõigi maade töölistele Nõukogude võimu toetamiseks Eestis, 29. november 1918”, Eesti Töörahva Kommuun, 43. 139 "V. I. Lenini telegramm vägede ülemjuhatajale Eesti, Läti, Leedu ja Ukraina Nõukogude valitsuste toetamise kohta, 29. november 1918”, Eesti Töörahva Kommuun, 44. Teiste nõukogude vabariikide asutamise kohta sama sihiga sel ajal vt Jerzy Borzecki, The Soviet-Polish Peace of 1921 and the Creation of Interwar Europe (Yale University Press, 2008), 14-15.
} 
loobus Venemaa suveräänsusest Eesti- ja Liivimaa üle ja kohustus hoiduma sekkumisest nende siseasjadesse. Samuti sätestati, et eralduvatele aladele ei jää mingeid kohustusi Venemaa vastu, mis on tingitud nende varasemast ühendusest. Järgnesid mitu üksikasjalikumat artiklit, mis puudutasid kaubandussuhteid Venemaaga (tolli- ja läbiveomaksude puudumine, madalad raudteetariifid, eritsoonid sadamates), Peipsi järve vee kasutamist, varade tagastamist, kodakondsusse opteerimist jne. ${ }^{140}$ Kas Eesti poleks võinud Saksamaa selle lepingu teise poolena välja vahetada? Ent milleks, milliste väljavaadetega, kui see öeldi üles niipea, kui sõjaline olukord muutus? Nõukogude valitsuse otsus lepingud tühistada heitis varju siin-seal säilinud veendumusele, et demagoogiale ja vägivallale vaatamata saab enamlastega kokku leppida. Kujunes mulje, et viimased ei ole juba loomu poolest võimelised tavapäraseks rahvusvaheliseks suhtlemiseks. ${ }^{141}$

Siiski ei olnud Nõukogude valitsus 1919. aastal liitlaste silmis ühemõtteliselt paaria. Aasta alguses tegid Suurbritannia ja Ameerika Ühendriigid katse tuua ühise läbirääkimistelaua taha enamlased ja teised Venemaa valitsemisele pretendeerivad jõud. Kavandatavat Printsi saarte (Prinkipo) nõupidamist põhjendati enesemääramise põhimõttega - venelastel endil tulevat lasta oma asjus otsuseid langetada. ${ }^{142}$ Eestlased teatasid alguses, et nende kohta kutse ei käi, kuna nemad ei pretendeeri võimule Venemaal. Need, kes esindavad Vene rahvast, võivat endid isekeskis määrata, kuid "Eesti valitsus, kelle ülesandeks Eesti rahva [...] kasude kaitsemine, ei või ega taha suure Vene rahva soovisid fikseerima ning ühtlustama minna, niisama nagu ta ei luba, et suur Vene rahvas või tema valitsus hakkaks Eesti rahva soovisid [...] ligemalt formuleerima, kindlaks määrama või neid koguni oma moodi ümber tegema." ${ }^{143}$ Osavõtuga oleks justkui mööndud, et Eestit nähakse osana Venemaast. Teisalt oli see võimalus pidada läbirääkimisi

\footnotetext{
140 27. augustil Berliinis sõlmitud Bresti lisalepingu teksti vt John W. Wheeler-Bennett, Brest-Litovsk. The Forgotten Peace, March 1918 (London: Macmillan and Co., 1966), 431-432.

${ }_{141}$ Ka Ants Piip, kõneledes mais rahu võimalusest, lisas juurde, et eelistatav oleks "sarnase kaubaga kokku [saada] oma vaenlastega, et nad meile mitte peale ei tungi, et meie, ilma vormilise lepingu tegemata, mille väärtus [...] enamlastega ju väga väikene, omale praktilise sõjategevuse seisma paneku saaks.” RA, ERA.1624.1.103, 1. 61: Piibu märkmed, mai keskpaik.

142 Vt Arno J. Mayer, Politics and Diplomacy of Peacemaking. Containment and Counterrevolution at Versailles, 1918-1919 (New York: Alfred A. Knopf, 1967), 413. Vt ka Keith Neilson, "That elusive entity British policy in Russia': the Impact of Russia on British Policy at the Paris Peace Conference", The Paris Peace Conference, 1919, ed. by Michael Dockrill, John Fisher (Palgrave, 2001), 80.

143 "Eesti välissaatkonna otsus kokkukutsutava nõupidamise kohta Printsi saartel", Postimees, 13.02.1919, 1.
} 
idavaenlasega. Herbert Hoover seletas Tõnissonile, et nõupidamise eesmärk on saavutada sõjategevuse lõpetamine ning eestlasedki võiks sinna minna vaherahu sõlmimiseks. ${ }^{144}$ Otsustatigi osaleda, kuid rõhutades, et ollakse endise Venemaa nüüdseks iseseisev osa. Piip kinnitas veebruaris Ameerika Ühendriikide esindajale Henry White'ile, et kavatsus oli enamlastega rahu tegemine.${ }^{145}$ Clemenceau'le teatati samuti, et Eestil on Prinkipo nõupidamisel ainult üks eesmärk: sõlmida Eesti Vabariigi ja Nõukogude Venemaa vahel rahu ja rääkida läbi tulevase vahekorra üle Venemaaga. ${ }^{146}$

Varakevadel oli rahu tegemine seega avalikult päevakorral ja mitte ainult liitlaste loal, vaid lausa Suurbritannia ja Ameerika Ühendriikide õhutusel. Olukord muutus, kui liitlased hakkasid taas senisest enam hellitama lootust Nõukogude võimu kukutada, ja Prinkipo kava maeti maha. Enamlaste taktika mõistmiseks peame silmas pidama, et rahuvõimaluste kompamine jätkus. Britid ja ameeriklased saatsid märtsis Moskvasse diplomaatilise agendi rahutingimustega, mille hulgas oli kohustus säilitada kõik endisel Venemaal asuvad de facto valitsused hetkel nende valduses olevatel aladel ja liitlaste lubadus oma väed teatud tingimustel Venemaalt välja tuua. ${ }^{147}$ Moskvas võeti läkitust väga tõsiselt, kuna kardeti, et tingimuste tagasi lükkamisel tugevdavad liitlased blokaadi ja sõjalist survet. Litvinovi koostatud ja Lenini heaks kiidetud vastuses pandi ette kutsuda kokku rahukongress ning seniks sõlmida vaherahu ja säilitada kõik de facto valitsused, "kuni ja kui elanikkond hääletab muutuse poolt" ${ }^{148}$ Lenini sõnul oli enamlastel kavatsus "korrata Bresti". ${ }^{19}$ 1918. aasta märtsis sõlmitud Brest-Litovski rahu on tihti kujutatud järgmise kaubana: Keskriikidele, esijoones Saksamaale, suured maa-alad ja ressursid idas, Venemaale hingetõmbeaeg, kindlustamaks kõikuvat Nõukogude võimu. Leppe tuum oligi selline, kuid enamlaste tagamõttes oli siiski rohkem nüansse. Võimu haaramise järel olid nad pakkunud kõigile riikidele üldist rahu 1917. aasta vormeli alusel: ilma anneksioonide ja kontributsioonideta, koos enesemääramise õigusega. Niisugust "demokraatlikku rahu” ei pakutud mitte ainult riikidele, millega Venemaa oli sõjas. Seati üles rahuläbirääkimiste programm tervele maailmale. ${ }^{150}$ Ka pärast seda, kui ettepanekust võtsid

\footnotetext{
$144 \quad$ RA, ERA.1619.1.3, 1. 1: Välisdelegatsiooni koosoleku protokoll, 26. jaanuar 1919.

145 RA, ERA.1619.1.3, 1. 32: Välisdelegatsiooni koosoleku protokoll, 12. veebruar 1919.

146 Vt Maaliit, 12.03.1919, 2.

147 Mayer, Politics and Diplomacy of Peacemaking, 463.

148 Louis Fischer, The Soviets in World Affairs, kd 1 (London: Jonathan Cape, 1930), 171.

149 John M. Thompson, Russia, Bolshevism, and the Versailles Peace (Princeton University Press, 1966), 164

150 Vt ülevaadet rahuläbirääkimiste programmist, 27. november 1917, Dokument $\bar{y}$ vneshně politiki SSSR, kd 1 (Gospolitizdat, 1958), 44.
} 
kinni ainult Keskriigid, rõhutas Vene delegatsioon, et tema eesmärk pole sõlmida separaatleping, vaid üldine ja õiglane rahu. ${ }^{151}$

Sellises olukorras oleks enamlaste maine ka tööliste hulgas kannatanud, kui Bresti läbirääkimistel oleks jalamaid jäetud keerutav jutt ja hakatud maid jagama. Kuna vastas olid Keskriigid, siis on raske kujutleda sedagi, et oleks asutud joonele tunnustada ainult tööliste vabadust. Vene delegatsioon naasis Brestis varasema vaate juurde, et enesemääramise õigus on kogu rahval. Kummalisel kombel ühtis see täielikult Saksamaa värske retoorikaga. Nõnda kujunesidki Bresti rahukõnelused üheks sürreaalsemaks episoodiks diplomaatia annaalides. Ühele poole lauda istusid enamlikud revolutsionäärid, teisele poole Keskriikide diplomaadid ja kindralid - et pikalt, kohati skolastilistesse kõrgustesse küündivate eristuste-jaotuste abil kõneleda rahva vabast otsustamisest, millest neil tegelikult, nagu kogemus oli näidanud, sooja ega külma ei olnud. Saksa delegatsiooni kuuluv välisasjade riigisekretär Richard von Kühlmann möönis hiljem otsesõnu, et tema plaan oli "tugineda rahvaste enesemääramise õigusele, õonestamaks anneksioonideta rahu kohta käivat punkti." 152 Trotski kaalutles, et enamlased võidavad igal juhul: kui Keskriigid "demokraatliku rahu” tingimustega ei nõustu, siis paljastavad nad oma tõelise palge ja kutsuvad kodus esile töölisrahutused; kui aga tingimused võetakse vastu, siis peab Saksamaa tegema Venemaa okupeeritud läänealadel olulisi järeleandmisi. ${ }^{153}$ Nõustunuks vastaspool Venemaa läänealade riikliku kuuluvuse määramiseks kasvõi rahvahääletusega, säilinuks enamlastel parem võimalus seal tulevikus kanda kinnitada.

Eelneva valguses on märksa selgem, millele viitas Lenini 1919. aasta märtsikuine lause, et rahu liitlastega olnuks Bresti kordamine. Läände saadetud ettepanekus nõustuti Venemaa alade jätmisega seal tegelikult valitsevate jõudude kontrolli alla tingimusel, et liitlaste sõjaväed sealt lahkuvad ning korraldatakse rahvahääletused alade lõpliku saatuse otsustamiseks. Ei saanud olla kindel, et kui enesemääramist teostab rahvas tervikuna, mitte "töörahvas", siis langeb liisk ühinemise poole Nõukogude Venemaaga. Kuid mõistagi ei kavatsenud enamlased oodata käed rüpes häälte lugemist Eestis ja mujal. Revolutsiooni mahitamine saanuks jätkuda. Punavägede rünnaku asendanuks katsed naaberriike seestpoolt pöörata. Liitlasvägede väljatõmbumine lihtsustanuks seda veelgi. Tõsi, tekib küsimus, miks sooviti uuesti alustada enesemääramise kometiga, kui enamlaste

151 “Pöördumine kõigi riikide töötavate masside poole, 9. detsember 1917", Dokument $\bar{y}$ vneshně politiki SSSR, $\mathrm{kd} \mathrm{1,} 58$.

152 Richard von Kühlmann, Erinnerungen (Heidelberg, 1948), 523.

153 Jacques Sadoul, Notes sur la révolution bolshevique (Paris: Maspero, 1971), 64. 
ebademokraatlik pale pidi selleks hetkeks olema kõigile paljastunud. Otsustav oli tõsiasi, et vähemalt Lenini arvates oli otsekohene revolutsiooniline strateegia läbi kukkumas: lootus peatsele revolutsioonile Saksamaal hääbumas ning lääneliitlaste ja Vene valgete sõjalise pealetungi oht suurenemas. Ja kui liitlastega taheti teha rahu - lausa oldi sunnitud tegema, nagu Bresti analoogia mõista andis -, siis olnuks äraspidine jätkata kohe pärast rahulepingu sõlmimist varjamata sõda Eesti ja teiste läänenaabrite vastu. Tuli valmistada ette suunamuutust. Kuna "tööliste enesemääramine" ei tahtnud sõjajõulgi teostuda, pidi naasma pikaajalise strateegia juurde, millest Lenin oli kõnelenud 1917. aastal: isegi avaramalt mõistetuna pidi see põhimõte ikkagi tasapisi sillutama teed revolutsioonile.

On ehk kiusatus arvata, et enamlased ei võtnud tõsiselt ühtki oma loosungitest. Punaarmee saatmine Eestisse Saksa okupatsiooni lõppemisel paistab tõendina, et enesemääramise õiguski oli nende suus paljas sõna. Ent sõjaline rünnak polnud eraldiseisev eesmärk. Keskne oli revolutsiooniline strateegia, mis muutus ja kohanes, kuid milles just seetõttu leidis 1919. aasta kevadel taas koha rahvaste õigus enesemääramisele. Ideoloogiline suunamuutus tuli jutuks kohe märtsis VIII parteikongressil. Nikolai Buhharin tõstis esile vastuolu, mis oli selleks hetkeks sündmuste valguses ilmseks saanud. Taotleti kõigi maade proletariaadi ühinemist ja diktatuuri, ent samal ajal andis parteiprogramm endiselt enesemääramise õiguse kuni lahkulöömiseni rahvastele, st kogudele, mis hõlmavad teisigi klasse. "Me peame praegusel ajal esitama sellise vormeli, mis ütleb, et me orienteerume proletariaadi diktatuurile ja püstitame rahvusküsimuses vastava loosungi." ${ }^{54}$ Lenin vastas teraval toonil. Buhharin tahtvat tunnistada ainult töölisklassi õigust enesemääramisele. "Järelikult Te tahate tunnistada seda, milleni pole jõutud tegelikkuses üheski riigis peale Venemaa. See on naeruväärne." Väideti, et tööliskond oli kodanlusest eristunud ja võis asuda iseseisvalt enesemääramisele, kuid Lenini sõnul polnud sellist eristumist veel toimunud ei Saksamaal ega teisteski riikides. Ta tõi näiteks Soome. Just seetõttu, et Nõukogude valitsus olevat tunnustanud viimase õigust enesemääramisele, kulgevat seal klasside eristumine ladusamalt. Arvestada tulevat ka vastaspoole propagandaga. Kuni töölised uskusid kodanlikke väiteid, et Venemaa soovib neile Nõukogude korda peale suruda, "seni ei lihtsusta vormel "tööliste enesemääramine" olukorda," märkis Lenin. Ei tohtivat käituda viisil, mis süvendab sellist muljet. Pealegi ei saavat "jätta tunnistamata seda, mis on olemas", kuna "[s]ee sunnib ennast ise tunnistama." Lenini sõnul tuli enamlastel oodata, käia

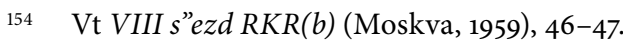


"käänulisi teid", arvestada tõigaga, et töölisklass võtab erinevates riikides kuju eripäraselt ja järk-järgult. ${ }^{155}$

Paistab kummalisena, et Lenin sihtis need mõtted Buhharini vastu. ${ }^{156}$ Oli ju tööliste enesemääramise loosungi käiku lasknud Nõukogude valitsus Lenini endaga eesotsas. Tõsi, Soomet oli Nõukogude valitsus 1917. aasta detsembris tunnustanud viitega mitte tööliste, vaid rahvaste enesemääramise õigusele. ${ }^{157}$ Kui Soome oli nii hea näide tee sillutamisest revolutsioonile, nagu Lenin 1919. aasta märtsikongressil ütles, miks anti siis 1918. aasta lõpus tunnustus mitte Eesti Vabariigile, vaid "Töörahva Kommuunile"? Määrav oli olupoliitika. 1918. aasta novembris tõukus see otsus sõjakäigust läände. Bresti rahuläbirääkimiste ajal oli olukord olnud teistsugune. 1918. aasta jaanuaris ei olnud Saksa väed Eestisse veel sisenenud ja Lenin kõneles Jaan Anveldiga kavast kuulutada Eesti iseseisvaks vabariigiks, "et saavutada tema tunnustamine ja luua seega väljavaateid Eesti okupeerimise vältimiseks". ${ }^{158}$ Sel ajal ei sobinud siduda enesemääramist kitsalt töölistega, sest vaevalt oleks mõne töörahvakommuuni “iseseisvus" kujutanud endast isegi vormilist takistust sakslaste edasitungimisele. ${ }^{159}$ Kui mais teatas Saksa välisministeerium Nõukogude saadikule Adolf Joffele, et Eesti- ja Liivimaa maapäevad on otsustanud Venemaast eralduda, siis vastas Joffe, et otsused lähtusid ainult väikesest rahvaosast. Olemaks kehtivad, pidanuks need tema sõnul langetama tõeliselt üldrahvalikul ja vabal hääletusel, mis eeldanuks okupatsioonivägede lahkumist. ${ }^{160}$ Kui Saksamaa väed novembris tõesti taandusid, siis polnud enam juttugi üldisest rahvahääletusest.

\footnotetext{
155 Ibid.

156 Buhhariniga oli Lenin rahvaste enesemääramise õiguse tunnustamise üle piike murdnud juba 1915. aastal, vt R. Craig Nation, War on War. Lenin, the Zimmerwald Left, and the Origins of Communist Internationalism (Durham, London: Duke University Press, 1989), 108.

157 "Rahvakomissaride Nõukogu otsus Soome Vabariigi tunnustamise kohta, 18 (31). detsember 1917”, Dokumenty vneshneı̌ politiki SSSR, kd 1, 71.

158 Daniil Rudnev, Lenin ja Eesti: kroonika (Tallinn, 1970), 122. Hans Kruus jutustas oma mälestustes, kuidas ta käis 1918. aasta jaanuari lõpus Petrogradis kohtumas Staliniga ning viimase jutust selgus, "et nädalat kolm varemini, kui keskriikide esindajad oma nõudmistes Brestis olid eriti järelandmatud ja sakslased ähvardasid okupeerida ka osa Eesti mandrist, olevat Vene rahvakomissaride keskel kaalutud Eestimaa iseseisvaks kuulutamist, et sel teel luua puhver, mis oleks tõeliselt kasulik nii Eesti kui Vene töörahvale", Hans Kruus, "Murdekuudel 1917-18: Mälestusi ühenduses G. Suitsuga", Looming, 9 (1933), 1026-1041 (1040).

159 Et Lenin vormile tähtsust andis, seda kinnitab tema vastus Anveldile, kes kahtles, kas mõni iseseisvust kuulutav paber sakslasi mõjutaks. Lenini sõnul ei tohtivat alahinnata asja formaalset külge, kuna "mõnikord etendab see rahvusvahelistes küsimustes teatavat osa"; vt Rudnev, Lenin ja Eesti, 122.

160 Chicherin, Stat'i i rechi, 42-43.
} 
Pigem oli tulnud tund töörahva kommuuni ellu äratamiseks. ${ }^{161}$ Ehkki viimast tunnustati 7. detsembril 1918 enesemääramise õigust mainimata, ${ }^{162}$ oli Eestile nüüd laiendatud käsitlust, mille järgi luges ainult tööliste tahe. ${ }^{163}$

1919. aasta märtsis, kui kavatseti "Bresti kordamist", olid tingimused jälle teised. Enamlased olid olukorras, mis sarnanes 1918. aasta kevadega: endise Venemaa läänealad olid vaenulike suurriikide mõju all ning parim, millele panustada, oli nõuda seal vabu rahvahääletusi. Naasmine endise enesemääramis-programmi juurde polnud aga ainult taganemine. Nagu Brestis, avanes nüüdki võimalus propagandarünnakuks, ja seda tõhusamaks, et liitlased olid justkui võtnud omaks "demokraatliku rahu" põhimõtted, kuid olid neid - nagu paljudele tundus - Pariisis parajasti reetmas. Punavägede tungimine läände tegi täpselt seda, mida Lenini sõnul tuli vältida: pööras välismaa töölised enamlaste vastu, kuna paistis õigustavat väiteid, et Nõukogude võimu soovitakse naabritele peale suruda. Kui enesemääramist võetaks olude sunnil tõsisemalt, kas siis ei õnnestuks kasutada ära liitlaste sõnamurdlikku käitumist Pariisis, samamoodi nagu tehti 1917. aastal Venemaal, kui enamlased trumpasid oma rahvusprogrammiga üle teised parteid ja toitusid ääremaade vastumeelsusest suurvene šovinismi suhtes? Enamlaste rahuvormel - ei anneksioonidele ja kontributsioonidele, jah enesemääramisele - oli jälle muutunud millekski, millega eristuda ja ideoloogiliselt konkureerida.

Märtsi alguses Lenini juhatusel peetud Kommunistliku Internatsionaali asutaval kongressil sarjatigi liitlasi ja Pariisi rahukonverentsi enesemääramise põhimõtte eiramise pärast. ${ }^{164}$ Kuulutati, et väikerahvastele saab tagada vaba arengu ainult proletaarne revolutsioon. ${ }^{165}$ Juba II Internatsionaali ajal oli Londoni 1896. aasta tööliskongress tekitanud probleemi, kui toetas ühelt poolt kõigi rahvaste õigust enesemääramisele, teisalt aga kutsus kõigi maade töölisi üles klassiteadlikule ja solidaarsele võitlusele

\footnotetext{
161 Juba 1918. aasta alguses oli välja töötatud "Eesti töörahva-kommuna” põhiseadus; vt Edasi, 23.01.1918, 2.

162 "VFSNV Rahvakomissaride Nõukogu dekreet Eesti Nõukogude Vabariigi iseseisvuse tunnustamise kohta", Eesti Töörahva Kommuun, 54.

163 Eesti erandlikkusest nõukogude poliitikas 1918. aastal annab tunnistust seegi, et jaanuaris toimunud III ülevenemaalisel nõukogude kongressil pidi Stalin nägema vaeva, põhjendamaks, miks nõudis partei Venemaa lääneprovintsides üldise rahvahääletuse korraldamist, mujal aga tahtis anda enesemääramise õiguse töölistele. Tema sõnul oli mõttetus nõuda läänepiirkondades nõukogude võimu, kuna seal polnud veel nõukogusidki. Stalin, Teosed, kd 4, 34-35.

164 Pervā̄ Kongress Kommunisticheskogo Internatsionala: protokolȳ zasedanī̌ v Moskve so 2 po 19 marta 1919 goda (Petrograd: Izdatel'stvo Kommunisticheskogo Internatsionala, 1921), 152.

165 Ibid., 206.
} 
rahvusvahelise kapitalismiga ${ }^{166}$ Kuidas need kaks lepitada? Omamoodi solidaarsus oli seegi, kui ühes riigis võimu haaranud töölised asusid sõjakäigule naaberriigi vastu, et vabastada seltsimehed. Ent kas sel juhul sai rünnatud riigi puhul kõnelda isegi tööliste enesemääramisest? Veenvam viis lepitada enesemääramise põhimõtet ja tööliste rahvusvahelist solidaarsust oli väita, et revolutsiooni ei tule mitte sõjajõul naabritele sisse viia, vaid iga riigi proletariaadil tuleb aidata end kehtestada. Rahvusriiklustki võis näha progressiivsena, kui usuti, et see soodustab klassiteadliku tööliskonna teket. Rahvaste enesemääramine tõotas tekitada riigipiire tööliste vahele, kuid neid piire pidi tunnustatama ajutiselt ja eesmärgiga sillutada just sel moel teed proletariaadi ühinemisele tulevikus. Sellisel teoorial oli kõigiti marksistlik ilme. Lisaks sobis see suurepäraselt 1919. aasta oludega, mis ei jätnud enamlastele teist võimalust, kui tunnistada seda, mis oli olemas.

Samasuguse paratamatuse ette jõudis 1919. aasta juuniks ka Eesti Töörahva Kommuun, mis oli punavägede sunnitud taganemisega kaotanud pinna jalge alt. Kommuuni nõukogu oli veidra järjekindlusega hoidnud kinni faabulast, et Ajutine Valitsus pidas võitlust Eesti töölishulkadega, kes olid põgenenud 1918. aasta märtsis Saksa sõjavägede eest Venemaale ja võeti vastu kuulidega, kui pärast sõda "kodumaa poole tõttasid" ${ }^{167}$ Nüüd tuli paljudel Eesti enamlastest tõtata teises suunas. 4. juunil tegi EKP Keskkomitee otsuse Eesti Töörahva Kommuuni nõukogu asutuste tegevus likvideerida ${ }^{168}$ VKP(b) Keskkomiteele ja Kominterni Täitevkomiteele kirjeldati olukorda kahetiselt: rahvas kaldub Eestis küll üha enam revolutsioonile, kuid vastumeelsust tekitab tunne, et enamluse sildi all taastatakse vana Vene riiki. ${ }^{169}$ Värskelt Tallinnast pagenud EKP Keskkomitee liige Martin Likemets rääkis juuni lõpus Petrogradis, et suurvene sissetungi muljet leevendaks ja sisemist revolutsiooni kiirendaks see, kui Nõukogude Venemaa

166 Verhandlungen und Beschlüsse des Internationalen Sozialistischen Arbieter- und Gewerkschafts-Kongresses zu London vom 27. Juli bis 1. August 1896 (Berlin, 1896), 18.

167 Aprilli lõpus esitas Ungari välisasjade rahvakomissar Tsarskoje Selo kaudu Eestile rahu vahendamise ettepaneku, täpsustamata, kes olid "sõdijad”, kelle vahel tuleks rahu sõlmida, vt RA, ERA.957.11.110, 1. 1: Ungari välisasjade rahvakomissar Tallinnasse, 25. aprill 1919. Kommuuni nõukogu rõhutas, et see oli katse pakkuda "vahemehekätt" kodusõja lõpetamiseks. "Eesti Töörahva Kommuuni läkitus seoses Ungari nõukogude vabariigi ettepanekuga sõjategevuse lõpetamise kohta Eestis”, Eesti Töörahva Kommuun, 129.

168 "Eesti Töörahva Kommuuni Nõukogu ja Venemaa Kommunistliku (bolševike) Partei Eesti seksioonide Keskkomitee otsus Eesti Töörahva Kommuuni Nõukogu asutuste tegevuse likvideerimise kohta, 5. juuni 1919”, Eesti Töörahva Kommuun, 135.

169 RA, ERAF.24.1.4, 1. 3: EKP Venemaa büroo ettekanne VKP(b) Keskkomiteele, 12. juuni 1919. 
pakuks rahu ja lubaks, et Punaarmee ei tule mingil juhul üle Eesti piiri. ${ }^{170}$ Eduard Laamani sõnul olid Eesti enamlased jõudnud otsusele, et punaväe toetus oli neile liiga kalliks maksma läinud: "ta oli kogu Eesti nende vastu mobiliseerinud ja sisemised enamlased halvanud". ${ }^{171}$ Vaevalt oli neil siiski otsustav roll Venemaa välispoliitika kujundamisel. Sõjalise rünnaku asendamine riigisisese revolutsiooniga oli täpselt see, mida Lenin oli märtsis üldise strateegiana soovitanud. Juunis Eestist saadud teated olid olulised selles mõttes, et kinnitasid Nõukogude valitsuse silmis Lenini väidete paikapidavust siinses olustikus - et imperialistlikuks vallutuseks peetav pealetung mitte ei hõlbusta, vaid takistab revolutsiooni. Välisasjade rahvakommisari Georgi Tšitšerini sõnul saadi pagulastelt teada sedagi, et Eestis on laiadel massidel igatsus rahu järele, millest võis järeldada, et Nõukogude rahuettepaneku korral avaldataks valitsusele survet see vastu võtta. ${ }^{172}$ Juuni lõpus otsustatigi Moskvas, et soodsa võimaluse avanemisel tuleb Eesti Vabariigiga rahu teha. ${ }^{173}$

Tšitšerini väitel oli Nõukogude rahuofensiivi algne motiiv kindlustada vähemalt üks osa rindest olukorras, kus vaenlased olid kõikjalt peale tungimas. ${ }^{174}$ Selleks tuli esmalt, nagu kohalikud enamlased olid soovitanud, anda lubadus, et punaväed ei sisene Eesti territooriumile. 4. juulil tegigi VK(b)P Keskkomitee pleenum välisasjade rahvakomissariaadile ülesandeks teatada, et Punaarmee austab Eesti ja Soome suveräänsust ja ei ületa nende riikide etnilisi piire. ${ }^{175}$ Tallinnas suhtuti niisugustesse teadetesse

$170 \quad$ RA, ERAF.24.1.4, 1. 15: EKP KK liikme Martin Likemetsa ettekanne VKP(b) Keskkomiteele ja Kominterni Täitevkomiteele.

171 Eduard Laaman, "Eesti Töörahva Kommuna ots. "Rahvusluse oopium”", Kaitse Kodu, 44/45 (1931), 984.

172 Chicherin, Stat'i i rechi, 135.

173 Richard K. Debo, Survival and Consolidation. The Foreign Policy of Soviet Russia, 1918-1921 (McGill-Queen's University Press, 1992), 124.

174 Chicherin, Stat'i i rechi, 136.

175 Mattisen, Tartu rahu, 188-189. Petrogradi Nõukogu ja Kominterni esimees Grigori Zinovjev kuulutas 10. juulil: selline poliitika sünnib teadmises et "Eesti töölised, meie vägede ligidust tundes, ülestõusevad ja oma kodanluse kõrisse kargavad." "Sm Sinovjevi kõne ülevenemaalisel kesktäidesaatva komitee koosolekul”, Edasi, 10.07.1919, 1. Vt ka RA, ERA.31.1.164, 1. 7: Zinovjevi 5. septembri läkitust Eesti töölistele, kus öeldi, et vastus juhtide väljaajamisele Eestist peab olema revolutsioonilise tegevuse elavdamine. Selle juures võivat loota "Vene proletariaadi kõige aktiivsemale toetusele". Kuna seni oli Vene vägesid märksa lähemalt tunda saadud ja kodanluse kukutamine polnud ikkagi õnnestunud, siis tähendas see sisuliselt, et revolutsiooniga tuli mõneks ajaks oodata. Sama mööndi, ehkki vihjamisi, ka EKP Keskkomitee 19. juuli manifestis. Võitluse käik kaheksa kuu jooksul olevat näidanud, et töörahvas peab ennast Eestis vabastama "otsekohese sisemise võitluse läbi kodanluse vastu." "Kommunistliku partei Eesti Keskkomitee manifest Eesti töörahvale”, Eesti Töörahva Kommuun, 142-143. 
umbusuga. Ometi nähti selles vihjet rahu tegemise võimalusele. ${ }^{176}$ Üle piiri toodi sõnum, mille järgi Moskva oli valmis tunnustama Eesti iseseisvust tingimusel, et ei tehta koostööd Loodearmeega ning välistatakse rünnak Nõukogude Venemaa vastu Eesti territooriumilt. ${ }^{177}$ Ehkki poliitbüroo oli juba augusti keskel andnud nõusoleku alustada rahuläbirääkimisi, ${ }^{178}$ saatis Tšitšerin ametliku ettepaneku alles 31. augustil. Enam ei pakutud vahemehekätt kodusõja lõpetamiseks. Ettekäändeks sobis nüüd tõik, et Eesti väed olid viinud läbi operatsioone Venemaa territooriumil. Tšitšerini telegrammi järgi oldi rünnakust hoolimata valmis määratlema Eesti piire ja rääkima läbi teistes küsimustes, mis olid ühenduses Eesti iseseisvuse tunnustamisega. ${ }^{179}$ Tallinnast teatati vastuseks, et sõjategevuse oli esile kutsunud Vene relvastatud jõudude tungimine Eestisse ja ainult seetõttu oli see nüüd kandunud Venemaale. ${ }^{180}$ See oli sobiv avatakt läbirääkimistele, mille käigus Ants Piip ütles, et kokku saab leppida ka siis, kui lähtutakse erinevatest arusaamadest. ${ }^{181} \mathrm{Kuid}$ vaatamata juba avatelegrammides puhkenud vaidlusele nähti Moskvas Eesti vastust paljulubavana. Poska telegrammis öeldi, et Eestigi on nõus alustama läbirääkimisi, määratlemaks kahe riigi vahekorda tulevikus (sama eesmärgi olid eestlased seadnud Prinkipo nõupidamisele). Tšitšerin märkis hiljem, et nende sõnadega anti eelseisvatele läbirääkimistele hoopis laiem iseloom kui see, mida Nõukogude valitsus alguses silmas pidas. Kõne all polnud enam pelgalt sõjategevuse lõpetamine, vaid täieliku rahulepingu sõlmimine. Järjest enam hakkas Moskvas paistma, et käsil on midagi murrangulist - peaproov rahu tegemiseks lääneliitlastega. ${ }^{182}$

\section{Tõrjutute käepigistus}

1919. aasta septembris olid nii Eesti kui ka Nõukogude Venemaa - olgugi erinevatel põhjustel - vastasrinnas liitlaste praktikaga enesemääramise põhimõtte sisustamisel. Moskvale oli see ideoloogiline võitlus. Pariis tembeldati imperialismi kantsiks, kus lööksõnadele vaatamata ei hoolitud kübetki rahvaste vabadusest. Eesti seisukoht oli samuti arvustav, kuid

\footnotetext{
176 August Rei, Mälestusi tormiselt teelt (Tallinn, Eesti Päevaleht, 2010), 397.

177 Kolonel Pirie-Gordon George Curzonile, 18.08.1919, Documents on British Foreign Policy, 1919-1939, seeria 1, kd 3 (London, 1949), 501 (edaspidi DBFP).

178 Debo, Survival and Consolidation, 127.

179 Asutava Kogu protokoll nr. 59, 12.09.1919, v 1448-1449.

180 Ibid.

181 RA, ERA.957.10.41, 1. 20: Tartu rahukonverentsi majanduskomisjoni 2. jaanuari 1920 istungi protokoll.

182 Chicherin, Stat'i i rechi, 137.
} 
kitsamal moel: liitlastele heideti ette seda, et ei austatud tema õigust enesemääramisele. Mõlema vaatevinklist olid algavad läbirääkimised alternatiiv Pariisile. Mitte selles mõttes, et kahepoolse kokkuleppega oleks loodetud saavutada seni teostumata rahvusvahelised eesmärgid. Kumbki ei läinud Pihkvasse mõttega, et teine pool annab talle selle, mida kõige enam vajatakse. Tõsi, vahetu siht oli sõjategevuse lõpetamine kahe riigi vahel. Kuid mõlemad nägid kõneluste alustamist laiema tähendusega diplomaatilise sammuna. Moskvas loodeti, et käsil on ettevalmistus rahu sõlmimiseks liitlastega. Poska arvas samuti, et britid soovivad hakata enamlastega läbi rääkima ja kasutavad Eestit esialgse sillana. ${ }^{183}$ Eestil avanes võimalus näidata enda kasulikkust kui mitte liitlastele üldisemalt, siis vähemalt Suurbritanniale. Samas ei olnud veel sugugi välistatud võimalust, et liitlaste tunnustuse saamiseks jätkatakse sõda - ja koguni osaletakse rünnakus Petrogradile. ${ }^{184}$ Enesemääramise loosung kujunes punktiks, kus nõukogude ideoloogiline joon lõikas sisse Eesti diplomaatilistesse pingutustesse läänes. Sõjaväe võitlusvaimu oli algusest peale ergutatud tunnustuse saamise väljavaatega. Eesti diplomaatide - ja iseäranis Poska - jutt sellest, et sõdimisvalmidus sõltub tunnustamisest, polnud mõeldud üksnes liitlaste veenmiseks. Moskva lubadus teha rahu enesemääramise põhimõtte alusel oli seda mõjusam, et Eesti valitsus oli selle põhimõtte teostamist ühtejärge nimetanud peamiseks sõjasihiks. Nagu Poska mainis, lõi iseseisvuse mittetunnustamine hea pinna enamlikule propagandale. Vaenlane oli Eesti piiridest väljas. Venemaale tungimist olnuks märksa raskem põhjendada enesemääramisega. ${ }^{185}$

Nõukogude delegatsiooni juht Leonid Krassin mainis juba enne Pihkva kõnelusi ajalehes, et tahab Eestile pakkuda enesemääramist (lisades kahtlustavalt, et Eesti eesmärk võib olla hoopis liitlaste survestamine tunnustuse saamiseks). ${ }^{186}$ Silmas peeti hoopis laiemaid ringkondi kui need, kellega vahetult kokku puututi. Enamlastele oli see kõige väljapaistvam ilmumine rahvusvahelisele areenile pärast Bresti kõnelusi. Kuna viibiti Vene vägede kontrollitaval territooriumil, ei saanud levitada lendlehti võõrriigi

\footnotetext{
$183 \quad$ RA, ERA.957.11.101, 1. 278: Poska Pariisi saatkonnale, 10. september 1919.

184 4. septembri kirjas Rahukonverentsi esimehele öeldi, et tõhusaim toetus Eestile oleks tema iseseisvuse tunnustamine, RA, ERA.1624.1.7, 1. 125: Eesti delegatsiooni kiri Rahukonverentsi esimehele, 4. september 1919.

185 RA, ERA.957.11.101, 1. 268, 273: Poska Pariisi, Londonisse ja Kopenhaagenisse, 31. august 1919; Poska Pariisi, Londonisse ja Kopenhaagenisse, dateerimata. Briti sõjalisele esindajale Harry Pirie-Gordonile ütles Poska septembri alguses, et läbirääkimisi alustati kõigest aja võitmiseks ja sõjaväe võitlustahte taastamiseks, vt $B D F P, 543$, allmärkus 1. 186 Mattisen, Tartu rahu, 225.
} 
sõdurite ja elanike hulgas. ${ }^{187}$ Otsekui kompensatsiooniks tõmmati Pihkvas istungite saali seintele suured punased kangad loosungitega. ${ }^{188} \mathrm{Nagu}$ Brestis, soovisid Nõukogude esindajad nüüdki, et läbirääkimiste protokoll avalikustataks. Kujukalt tuli nähtavale enamliku diplomaatia eripära, mis avaldus iseäranis 1919. aastal, mil Nõukogude võimul puudusid harjumuspärased kanalid rahvusvaheliseks suhtluseks: kõnetati rahvast, mitte pelgalt valitsusi. ${ }^{189} \mathrm{Ka}$ Pihkvas esitas Vene pool oma tingimuste alusena põhimõtted, mis väljendasid laiemat õiglase rahu ideoloogiat. Bresti kõnelused oli Adolf Joffe avanud üleskutsega teha üleilmne rahu enamlaste vormeli põhjal. ${ }^{190}$ Pihkvas tegi samal moel otsa lahti Krassin, koos päevakajalise täiendusega, mille järgi olevat möödunud kuude sündmused näidanud, et rahu tegemine polegi võimalik teisiti kui Nõukogude valitsuse püstitatud alustel, rahvaste enesemääramise õiguse põhjal. "Tõendi selle väite kohta pakub nn Versailles' rahu," märkis Krassin, haarates kinni võimalusest teha maha lepingut, mida Lenin ja Tšitšerin olid hiljuti kirjeldanud imperialismi uusima ilminguna. ${ }^{191}$ Birk vastas eestikeelse kõnega, kus tõstis esile Asutava Kogu seletust Eesti iseseisvuse kohta, mis olevat kogu maailmale teada antud. Kuna Eesti kaitsvat üksnes oma õigust enesemääramisele, polevat tal olnud mingit põhjust jätta Nõukogude Venemaa ettepanekut tähelepanuta, eriti kuna viimane seda õigust tunnustas. ${ }^{192}$

Birgi sõnadest aimub soov õigustada end liitlaste ees. Oma sihtide täpsustamisega anti veel kord mõista, mida tuleks pakkuda, veenmaks eestlasi rahu tegemisest hoiduma. ${ }^{193}$ Nõnda saab Pihkva läbirääkimisi käsitada

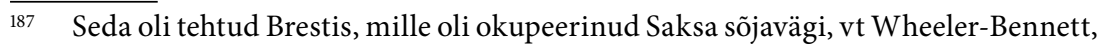
Brest-Litovsk, 88 .

188 Rasmus Kangro-Pool, “Septembri rahukonverents Pihkvas 1919. a.”, Vabadussõja lood, 6 (1937), 164.

189 Selle eripära, nn revolutsioonilise diplomaatia kohta vt Teddy J. Uldricks, Diplomacy and Ideology. The Origins of Soviet Foreign Relations, 1917-1930 (London, Beverly Hills: SAGE Publications, 1979), 61.

190 Proceedings of the Brest-Litovsk Peace Conference (Washington, 1918), 14.

191 RA, ERA.957.10.22, 1. 33: Pihkva rahukonverentsi protokoll, 17. september 1919. Nõukogude kriitikat Versailles'i rahulepingu aadressil vt Thompson, Russia, Bolshevism, and the Versailles Peace, 320-321.

192 RA, ERA.957.10.22, 1. 63-64: Ado Birgi sõnavõtt Pihkva rahukonverentsil.

193 Piip ütles usutluses Reuterile, et eestlaste soovi enamlastega sõdida oli nõrgendanud de jure tunnustuse viibimine. RA, ERA.1624.1.7, 1. 128: Ants Piibu usutlus, dateerimata. Poska palus Pariisi ja Londoni saatkondadel ajakirjandusele teatada, et ettepaneku vastuvõtmisel talitati Prinkipo algatuse vaimus, mille järgi prooviti igale rahvale tagada rahumeelse kokkuleppega need õigused, mille eest võideldi, RA, ERA.957.11.26, 1. 113: Poska saatmata telegrammi tekst Pariisi ja Londoni saatkondadele, dateerimata. 
varasema läänesuunalise diplomaatia jätkamisena. ${ }^{194}$ Briti sõjaväemissiooni juht Baltimaades Hubert Gough oli Poskale augustis lubanud, et püüab nõutada oma valitsuselt Eestile tunnustust (viimase oli Eesti valitsus seadnud Petrogradi operatsioonis osalemise tingimuseks). ${ }^{195}$ Goughi antud ülevaate põhjal esitas Balfour 20. augustil Pariisis liitlaste delegatsioonijuhtide kohtumisel eestlaste nõudmisi üsna dramaatiliselt: nad hoidvat liitlaste pea kohal püstolit, sest kui tehakse teoks ähvardus enamlastega kokku leppida, siis polevat ka teistel enam võimalik enamlastega sel territooriumil võidelda. ${ }^{196}$ Pärast Pihkva kõnelusi oli see hoiatus veelgi kaalukam. ${ }^{197}$ Pole kahtlust, et rahu tegemisele mõeldi tõsiselt, ${ }^{198}$ ent see ei välistanud alternatiividele panustamist. Septembri lõpuski küsiti liitlastelt, kas ei oleks võimalik tunnustusega aidata Eesti valitsust "veenda oma rahvast ja sõjaväge, et vaja on teha täiendavaid jõupingutusi enamliku võimu kukutamiseks Venemaal". ${ }^{199}$ Ka enamlastelt saadud tunnustusel olnuks väärtus esijoones läänes, kuna selles saanuks näha Venemaa nõustumist Eesti eraldumisega. ${ }^{200}$ Samamoodi nagu enamlastel tuli Lenini sõnul käia käänulisi teid, oli eestlastel 1919. aasta varasügisel üha enam põhjust uskuda, et tee läände kulgeb idast.

Häda oli selles, et liitlaste tahtmine oli septembris oraakellikult tume. Kui Londonisse teatati kavatsusest Moskvaga läbi rääkida, siis kuuldi, et Briti valitsus ei toeta rahu tegemist, sest soovib säilitada ühtse enamlusevastase

\footnotetext{
194 Pariisi rahukonverentsi esimehele Clemenceau'le kinnitati, et läbirääkimised enamlastega pole muutnud eestlaste veendumust, et ainult liitlaste abiga saavutavad nad oma suurima sihi - täieliku iseseisvuse. RA, ERA.957.11.124, 1. 201: Eesti delegatsiooni kiri Rahukonverentsi esimehele, 29. september 1919.

195 RA, ERA.957.11.101, 1. 255: Poska Pariisi ja Londoni, 16. august 1919; Poska kindral Marshile, 16. august 1919, DBFP, kd 3, 508-509.

196 Viie Suure delegatsioonijuhtide kohtumise protokoll, 20. august 1919, DBFP, kd $1,448$.

197 Poska palus siiski Piibul Pariisis Briti esindajale selgitada, et liitriikidele ei taheta avaldada survet, "sest kui meie heaga nendelt tunnistamist pole saanud[,] siis lootuseta teisel teel saada". RA, ERA.957.10.2, 1. 83: Poska Pariisi saatkonnale, dateerimata. Et tegelikult oldi valmis survet avaldama, seda näitab kasvõi tunnustuse tingimuseks seadmine Loodearmee abistamisele.

198 On ebaselge, kui suuri lootusi pani Poska alguses rahukõnelustele. Ta avaldas kahtlust, kas neist midagi välja tuleb. RA, ERA.957.11.26, 1. 147: Poska Pariisi ja Londonisse, dateerimata.

199 RA, ERA.957.11.124, 1. 200: Eesti delegatsioon Rahukonverentsi esimehele, 29. september 1919 .

200 Paistab, et Piip ja Pusta osutasid sellele võimalusele, kui käisid 12. septembril Prantsuse välisministeeriumis selgitamas, miks Eesti ei saa keelduda läbirääkimistest Nõukogude valitsusega. Neile öeldi, et enamlaste tunnustus ei mõjutaks liitlasi andma otsekohest ja täielikku de jure tunnustust; vt "Dokumente Prantsuse välisarhiivis (1)", Eesti Päevaleht, 22.07.1987, 8; vt ka RA, ERA.1624.1.7, 1. 142: Piip Tallinnasse.
} 
rinde Soomest Poolani. ${ }^{201}$ 17. septembril ütles Briti sõjaväesindaja Harry Pirie-Gordon Poskale, et Eesti valitsusel palutakse hoiduda ühepoolsetest sammudest ja sobitada oma välispoliitika liitlaste kavadesse, millele Poska vastas, et seda tehtaks meeleldi, kui teataks, millised need kavad õieti on (siiski lubas ta, et isegi vaherahu ei sõlmita brittide nõusolekuta). ${ }^{202}$ Asja ei teinud selgemaks Briti konsuli 28. septembri kiri, milles öeldi: on eestlaste endi otsustada, kas sõlmitakse kokkulepe Nõukogude võimudega, ja kui jah, siis milline. ${ }^{203}$ Samasugust ebamäärast nõu andis ka Prantsusmaa, ehkki manitsevamal toonil. Niisiis võib enamlastega rahu tegemise kavandamise jätkamist septembri lõpus pidada omatahtsi tegutsemiseks üksnes selles mõttes, et järgiti liitlaste nõu ise otsustada. Olukord ei olnud võrreldav 1917. aasta sügisega, mil Maanõukogu tõi õigustuseks Nõukogude enesemääramisdekreedi, et teha seda, mida oleks teinud niigi. Ei tahetud kasutada liitlaste vormilist luba, vaid katsuti mõista, mida sisuliselt öelda taheti, talitamaks selle järgi. Valitsuses kardeti, et vabaduse jätmine tähendas hoiatust: tehke, mida soovite, ent siis talute tagajärgi, kuna satute isolatsiooni. Pariisist Londoni kaudu Eestisse saabunud Piip seletas, et brittide ametlik seisukoht ei väljendanud nende tegelikku poliitikat. Poska, Tõnisson ja Jüri Jaakson ei tahtnud seda uskuda. ${ }^{204}$ Edasi hakati liikuma samm-sammult, hoides avatuna mitmeid võimalusi ning katsudes hankida täpsemat teavet brittide soovidest.

Vähemalt oli selge, et piiririikidel oli eelistatav teha rahu Nõukogude Venemaaga ühiselt. Piibu sõnul pani Poska Balti koostööle nii suurt rõhku, et "esialgsete rahuläbirääkimiste ja ettevalmistuste tõsiseks sihiks seadis tema Balti Liidu teostamise, et muidugi seda võimsamini pärast üheskoos ka rahutegemisele minna, kui aeg tulnud." ${ }^{205}$ Võis arvata, et kollektiivselt õnnestub kätte saada paremad rahutingimused. ${ }^{206}$ Tähtsusetu ei saanud olla ka tõik, et nõnda oleks hoopis paremini sobitutud liitlaste kavadesse millised need ka polnud. ${ }^{207}$ Septembri lõpus koguneski Tartus Balti riikide

\footnotetext{
$201 \quad$ RA, ERA.957.11.123, 1. 166: Telegramm Londonist, dateerimata.

202 RA, ERA.957.10.4, 1. 48: Kolonel Pirie-Gordon Eesti välisministrile, 18. september 1919; 1. 57: Poska kolonel Pirie-Gordonile, dateerimata; Kolonel Pirie-Gordon krahv Curzonile, BDFP, kd 3, 558-559.

203 RA, ERA.957.10.4, 1. 55: Bosanquet Poskale, 27. september 1919.

204 RA, ERA.1624.1.17, 1. 5: Ärakiri Piibu kirjast Eduard Laamanile, 7. september 1920.

205 RA, ERA.1583.1.260, 1. 4: Piibu märkused tunnustuse saavutamise taktika kohta, 1920. aasta.

206 Vt Poska sõnavõttu Asutavas Kogus, 10.02.1920, Asutava Kogu III istungjärk, v 274.

207 Suvel oli Poskale jäänud vestluste põhjal Briti esindajatega mulje, et Suurbritannia soovib luua Eesti, Läti ja Leedu sõjalist liitu. RA, ERA.957.11.101, 1. 263: Poska Pariisi saatkonnale, dateerimata. Liitlastele saadetud kirjas, mis paistab suuresti kajastavat Poska mõtteid, öeldi Balti sõjalise koostöö kohta, et see "teeks algust selle "sanitaarkordoni"
} 
II konverents (esimene oli toimunud 14.-15. septembril Tallinnas). Päevakorral oli ühiste rahutingimuste sõnastamine. Tingimuste esitamiseks oli Poska sõnul õige aeg, kuna enamlased olevat parajasti sõjalistes raskustes. Eesti, Läti, Leedu ja Soome olid kõik päri nõudmisega, et Venemaa peab tunnustama enesemääramise õigust. Konverentsil aga selgus kiiresti, et enesemääramisest saadi aru erinevalt. Soome peaminister Juho Heikki Vennola pakkus, et piirid tuleb tõmmata etnograafilisel alusel, kui rahvas seda soovib. ${ }^{208}$ Silmas peeti eelkõige Venemaa koosseisu kuulunud IdaKarjalat, kuid Petrogradi vallutamise eest olid soomlased nõudnud teisigi alasid. ${ }^{209}$ Leedulased nõustusid etnograafilise piiriga, kuid väitsid, et Vilna puhul on rahvahääletus mõeldamatu. Rahvuse määratlemisel polevat keel peamine, kuna leiduvat leedulasi, kes kõnelevad teisigi keeli (sh poola keelt, nagu enamik Vilna elanikke). ${ }^{210}$ Konverentsi juhatanud Otto Strandmann väljendas kummastust. Ta ei saavat aru, mis leedulased need on, "kes mitte leedu keelt ei mõista." ${ }^{211}$ Eestlased ei saavat kuidagi tagada Leedu piire ja sekkuda nõnda Leedu-Poola suhetesse. Poska sõnul oli esmatähtis teha rahu, tagatistele võivat mõelda hiljem. ${ }^{212}$

Nõnda ilmnesid juba 1919. aasta sügisel vastuolud, mis nurjasid tugeva piiririikide liidu sõdadevahelisel ajajärgul. Poska võttis probleemipuntra hästi kokku: tagatiste vastu peab igaüks saama seda, mida annab, Balti riike ähvardasid aga erinevad ohud. ${ }^{213}$ Lätlaste põhimure oli Kuramaad okupeerivad sakslased, leedulased seadsid esiplaanile vahekorra Poolaga, soomlased ilmutasid kasinat huvi lõunanaabritega ühiselt tegutseda, rääkimata sellest, et nende territoriaalsed nõuded Venemaale ähvardasid takistada rahu tegemist. Balti riikide II konverentsil vastu võetud ühistes tingimustes märgiti, et Venemaa peab andma enesemääramise õiguse ka Olonetsi (Aunuse) ja Arhangelski soome soost elanikele ja, niivõrd kui võimalik, eestlastele ja soomlastele Ingerimaal. ${ }^{214}$ Ehkki oli justkui loodud ühtne diplomaatiline rinne, pidid eestlased endalt küsima, kas enamlastega

teostamisega, mida liitlased on soovinud luua enamliku Venemaa ümber, takistamaks Saksamaa laienemist Venemaale.” RA, ERA.957.11.124, 1. 200: Eesti delegatsioon Rahukonverentsi esimehele, 29. september 1919.

208 RA, ERA.957.11.70, 1. 48: II Balti riikide konverentsi protokoll.

209 Vt Richard H. Ullman, Britain and the Russian Civil War, kd 2 (Princeton University Press, 1968), 259.

210 Vilna oli sel ajal Poola vägede käes; vt ka Alfred Erich Senn, The Emergence of Modern Lithuania (Columbia University Press, 1959), 147.

211 RA, ERA.957.11.70, 1. 48: II Balti riikide konverentsi protokoll.

212 Ibid., 42.

213 Ibid.

214 RA, ERA.957.11.70, 1. 28: Nelja Balti riigi tegevuskava. 
ollakse valmis kõnelema ka üksi. Oktoobris alanud Loodearmee Petrogradi operatsiooni esialgse edu harjal tekkis mulje, et enamlaste langemine pole enam kaugel. Sellises meeleolus otsustas Eduskunta enamlaste rahupakkumise tagasi lükata (mõned rahvaesindajad arvustasid isegi Soome osavõttu Balti riikide konverentsidest) ${ }^{215}$ Eesti suhted Lätiga pingestusid lõunanaabri sõjalise abistamise tingimuste üle kauplemisel sedavõrd, et läbirääkimisi juhtinud Poska tõdes meelepahaga: mõned lätlased kujutlevad riikide vahekorda sellisena, "kus nemad ikka võtjad oleksid ja ei kunagi andjad." ${ }^{16}$ Balti liidu kava oli ummikus nii lõuna- kui ka põhjasuunal. Sõja raskus lasus peamiselt Eestil, kuna Soomel polnud enamlastega sõjalisi kokkupõrkeid, samuti oli rinne vaikne lõunas. ${ }^{217}$ Poska arvates pidi sellises olukorras iseseisvuse kindlustamiseks otsima teisi abinõusid. "Kas ei ole peale Soome silla ka teisi sildasid olemas? Ja kas ei ehitata sildasid peale vee ka üle kuristikkude?" 218

Septembri keskel oli Poska teinud valitsusele ettepaneku moodustada ministeeriumitevaheline komisjon, töötamaks välja rahutingimused, mis puudutaks sõjaliste ja majanduslike teemade kõrval ka tulevast vahekorda Venemaaga ${ }^{219}$ See on kõnekas tõsiasi, sest ametlikult rõhutati samal ajal, et Nõukogude võimu puhul saab tulla kõne alla vaid vaherahu. Poska seletas välisajakirjandusele, et üksikasjalikku rahulepingut ja diplomaatiliste sidemete sõlmimist ei tasu oodata - enamlastelt soovitavat vaid tagatisi sõjategevuse lõpetamiseks. ${ }^{220}$ Albert Kammerer ütles Piibule ja Pustale, et poliitilised punktid lepingus oleks Prantsusmaa silmis tühised. ${ }^{221} 28$. septembri läkituses Clemenceau'le viitas Eesti valitsus aga juba püsivama rahu saavutamise väljavaatele, vaherahu esitati teise võimalusena juhuks, kui esimene eesmärk ei teostu. ${ }^{222}$ Rahusõlmimise eeltööde komisjon astus Piibu juhatusel kokku 12. oktoobril. ${ }^{223}$ Lepingu visandlik kava valmis mõned päevad hiljem, kuid arutlusele tuli see alles oktoobri lõpus, kui

\footnotetext{
215 Soome välisministeerium Soome saatkondadele, 18. oktoober 1919, raamatus: Eesti ja Soome suhted 1920-1925, koost Heino Arumäe (Tallinn, Umara, 1997), 52.

216 Dr. Pigrini [Jaan Poska], "Eesti-Läti entente-cordiale ja teised arusaamatused", Tallinna Teataja, 31.10.1919, 2; Ants Piip, “Tartu rahu”, Mälestused iseseisvuse võitluspäevilt, kd 2 (Tallinn: Vaba Maa, 1930), 374-375.

217 Vt Poska sõnavõttu Asutavas Kogus, 10.02.1920, Asutava Kogu III istungjärk, v 273.

218 Dr. Pigrini [Jaan Poska], "Eesti-Läti entente-cordiale ja teised arusaamatused", 2.

219 RA, ERA.957.11.61, 1. 79: Poska ettepanek Vabariigi Valitsusele, 13.[?] september 1919.

220 RA, ERA.1624.1.7, 1. 127: Poska seletused ajakirjanikele, dateerimata.

221 RA, ERA.1624.1.7, 1. 160: Piip Tallinnasse.

222 RA, ERA.957.11.124, 1. 201: Eesti delegatsiooni kiri Rahukonverentsi esimehele, 29. september 1919.

223 RA, ERA.957.11.61, l. 2: Välisministri päevakäsk, 10. oktoober 1919.
} 
Loodearmee pealetung Petrogradile oli juba luhtunud. ${ }^{224}$ Arutelu jätkus 5. novembril. Ehkki koostati täielikku rahulepingut, teatas välisministri kohusetäitja Piip, et viimane jääb tulevikuks, kuna Lätil ja Leedul oli soov teha üksnes vaherahu. ${ }^{225}$

Koos rahu tegemist sai mõista mitmeti. Eeldatavalt tähendas see mitme kahepoolse lepingu sõlmimist samal ajal. Sellise lahenduse suunas liikumist näitab tõik, et Eesti kavas oli Nikolai Maimi sõnastatud punkt, mille järgi pidi Venemaa rahvaste enesemääramise "põhjusmõtet" omaks võttes tunnustama Eesti riigi rippumatust ja iseseisvust ilma tagamõtteta, nagu see Eesti Asutava Kogu poolt 19. mail 1919 välja kuulutati, ja ütlema "ennast lahti vabatahtlikult igaveseks ajaks kõigist suveräänsist õigustest, mis Veneriigil on olnud Eesti maa ja rahva kohta tema allpool äratähendatud etnograafilistes ja riiklistes piirides, senini maksva avaliku ja õiguslise korra ja tehtud rahvusvaheliste lepingute põhjal, mis seega siin äratähendatud mõtes täies ulatuses oma jõu edaspidise aja jaoks kaotavad."226 Enesemääramisele viitamises võib näha soovi sõnastada üldine põhimõte, millest kõik järgnevad tingimused - iseäranis etnograafilised piirid - justkui loomuldasa tulenevad. II Balti riikide konverentsil käsitati enesemääramist eeskätt just riigipiiride määratlemise vaatevinklist. Kuid Maimi kavas oli ka üks veidi kummaline punkt: "Veneriigi valitsus aitab kaasa Eesti riigi rippumatuse ja iseseisvuse õiguslist tunnistamist teiste riikide poolt kätte saada ja loobu[b] igasugusest tegevusest, mis selle tunnistamise kättesaamisele võiks takistuseks olla." ${ }^{227}$ Raske öelda, mida muud, kuid see punkt näitab seda, et esialgse kava koostamisel mõeldi rahulepingule kui vahendile, saamaks lääneriikidelt tunnustus. Miks mainida Venemaaga sõlmitavas lepingus Asutava Kogu seletust? Meenutagem, et Eesti diplomaadid olid Pariisis argumenteerinud juristile sobival viisil: rõhutati, et lisaks enesemääramise õigusele kui üldisele reeglile oli Eesti rahvas teinud selge tahteavalduse (seda õigust kasutanud). Asutava Kogu seletuse vastuvõtmine oli ise tõukunud välispoliitilisest vajadusest. Oktoobris-novembris

$224 \quad$ RA, ERA.957.10.44, 1. 2: välisministrile saadetud rahulepingu kava, 17. oktoober 1919; RA, ERA.957.10.44, 1. 3: märkmed rahulepingu kava arutamise kohta, 27. oktoober 1919. Iseseisvuse tunnustamist puudutava sõnastamine jäeti Nikolai Maimi hooleks. RA, ERA.957.10.44, 1. 11: Märkmed ülesannete jaotuse kohta rahulepingu kava koostamiseks, dateerimata.

225 RA, ERA.957.10.44, 1. 14: Rahulepingu kava arutava koosoleku protokoll, 5. november 1919. Sõjaministeeriumis ei tegeletud lepingu kavaga üldse, kuna kindralid Larka ja Soots arvasid, et rahust enamlastega ei tule midagi välja. RA, ERA.957.10.44, 1. 20: Rein Eliaseri teade.

226 RA, ERA.957.10.44, 1. 32: Nikolai Maimi koostatud rahulepingu kava.

227 Ibid. 
koostatud kava järgi sõlmitud rahuleping näidanuks, et ka Nõukogude Venemaa silmis oli Eesti mais 1919 kasutanud oma õigust enesemääramisele. Eesti vaatevinklist polnud ükskõik, millisel alusel tema iseseisvust tunnustatakse. Eelistatav oli, et seda tehtaks alusel, millele tugineti suhetes liitlastega, kuna nõnda oleks kaudselt kindlustatud oma üldist rahvusvahelist seisundit. See ei olnud vastuolus käsitlusega, et Eesti eraldus emamaa loal. Üks täiendas teist. Kui Nõukogude võimu luba ei peetud kehtivaks, siis ei saanud ometi eitada, et oli üks võim, mis nägi Eestit enesemääramisvõimelisena.

9. novembril Tartus alanud III Balti riikide konverents kinnitas, et Läti ja Leedu hoidusid nii kaugele küündivatest kavadest. Kumbki ei soovinud teha lõplikku rahu enne liitlasi ega võtta vaherahulepingusse iseseisvuse tunnustamise punkti. Leedu esindaja sõnul tekkinuks vastasel korral oht, et enamlased nõuavad ka enda tunnustamist. ${ }^{228}$ Eestile aga jäid vabad käed, seda enam, et otsustati teha kolm eraldi lepingut. ${ }^{229} 16$. novembril jõudis Tartusse Nõukogude esindaja Maksim Litvinov, kes teatas, et enamlased tahaksid kohe sõlmida täieliku rahulepingu, mitte piirduda vaherahuga. ${ }^{230}$ Lätlased taganesid veelgi ja ütlesid, et nemad ei saa teha isegi vaherahu, kuna jääksid sel juhul ilma liitlaste toetusest. ${ }^{231}$ Kas nüüd, pärast teiste äralangemist, kui Eesti oli ainsana rahulepingu sõlmimise poolt, võis viimaks minna separaatkõnelustele? Piip oli poolt. Pärast enamlikku revolutsiooni oli ta kinnitanud, et uus võim jääb püsima. Tal oli olnud õigus: 1919. aasta novembris olid Vene valgete väed löödud ja enamlased Moskvas paigal kindlamalt kui kunagi varem. Poliitiline instinkt kinnitas Piibule, et vaja on rahu. ${ }^{232}$ Poska seisukoht polnud nii sirgjooneline. 10. novembril ütles ta Piibule, et separaatkõnelustele ei või minna. "Pidage meeles, et siht pole mitte rahu, vaid Balti liit." ${ }^{\text {233 }}$ Mõistagi polnud asi selles, et Poska ei soovinud rahu. Kuid tema arvates oli enamlaste rahupakkumine samasugune pettus nagu nende enesemääramise dekreet, millel polevat tegelikkuses põrmugi väärtust olnud. "Et nad meile nüüd rahu pakuvad, see ei tähenda veel, et

\footnotetext{
228 RA, ERA.957.11.70, 1. 127: Balti riikide kolmanda konverentsi protokoll, 10. november 1919.

229 RA, ERA.957.11.70, 1. 117: Balti riikide kolmanda konverentsi protokoll, 14. november 1919.

230 RA, ERA.31.1.1570, 1. 2: Piip peaministrile, välisministrile ja sõjavägede ülemjuhatajale, 17. november 1919.

231 RA, ERA.31.1.1570, 1. 4: Piip peaministrile, välisministrile, 18. november 1919.

232 Piip. "Tartu rahu”, 376, 378-379; RA, ERA.957.11.111, 1. 41: Piip saatkonnale Londonis, 8. november 1919.

233 RA, ERA.1624.1.99, 1. 169: Piibu märkmed tööerakonna rolli kohta rahu tegemisel, dateerimata.
} 
nad teisiti mõtlema on hakanud. Ei sugugi. Asjaolud sunnivad neid seda tegema, meie peame neid asjaolusid oma kasuks ära tarvitama, aga meie ei tohi sealjuures silmapilgukski ära unustada, et nad esimesel võimalusel uuesti meie kallal on."234

Otsus jäi Jaan Tõnissoni valitsusele, mis astus ametisse 18. novembril ja kogunes järgmisel päeval rahu tegemise üle nõu pidama. Piibule jäi mulje, et separaatkõnelustele minekul sai kaalukeeleks tema "osav käik" (nagu põllutööminister Theodor Pool seda nimetas): Tartust saadetud eksitav teade, et ka lätlased ja leedulased olid valmis kaasa tulema, kuigi ei saanud seda avalikult tunnistada. ${ }^{235}$ Paistab, et tegelikult lugu nii polnud. Valitsus oli juba enne otsustanud, et kõnelusi alustataks ka Läti ja Leeduta. ${ }^{236}$ Piibu üks eesmärk oli tõmmata kaasa Poska, kes oli küll vastu separaatrahule, kuid oli nõustunud asuma rahudelegatsiooni etteotsa. ${ }^{237}$ Milline oli Poska hinnang olukorrale, kui ta detsembri alguses kõnelusi juhtima hakkas? 19. novembril oli ta maininud Loode-Venemaa valitsuse liikmetele Stepan Liazonovile ja Manuil Marguliesile, et lõplikku rahu enamlastega ei tehta, vaherahu olevat aga sõdurite kurnatuse ja sõja maksumuse tõttu vajalik. Poska väitis, et Denikinilt ja Koltšakilt saadava tunnustuse toel oleks võimalik hankida tunnustus lääneliitlastelt, mis aitaks Eesti Rahvasteliitu. ${ }^{238}$ Viimane pakkunuks isegi suuremat kindlust kui Balti liit, sest Rahvasteliit tõotas kujuneda peaaegu kõigi suurriikide ühenduseks - nii vägevaks, "et keegi üksik riik ei suuda ta vastu üles astuda." ${ }^{339}$ Ent see oli kõigest tulevikuväljavaade - Rahvasteliit oli alles "paberilibakas". ${ }^{40}$ Seega pidi Poska arvates ikkagi mõtlema Balti liidule, katsuma sinna haarata Poolat, orienteeruma Suurbritanniale - mis olevat Eesti välispoliitika A ja O -, unustamata Prantsusmaad. Küllap pidas Poska just neid sihte silmas, kui ütles, et Moskva rahupakkumist tuleks kasutada enda huvides. Helsingist kuulis ta

\footnotetext{
234 Dr. Pigrini [Jaan Poska], “Balti liit ja Poola huvid”, Tallinna Teataja, 21.11.1919, 2.

235 Väljavõte Theodor Pooli päevikust, Vaba Maa, 02.02.1935, 2.

236 Tõnisson teatas Piibule 19. novembri õhtul: "See seisukoht võeti enne Teie teadaande siiajõudmist”. Valitsus kutsuti küll pärast Piibu teadet uuesti nõu pidama, kuid seisukohta ei muudetud; RA, ERA.957.10.45, 1. 4: sõnumivahetus Tõnissoni ja Piibu vahel, 19. november 1919. Valitsuse 19. novembri protokollis on märgitud: "Ei pea Läti, Leedu ja Soome ühinema, siis on valitsus valmis ka eraldi rahuläbirääkimisi pidama." RA, ERA.31.1.13, 1. 26o. (Protokoll ei täpsusta, mis kell see otsus langetati ja kas seisukohta muudeti). Theodor Pooli sõnul oli läbirääkimiste alustamise poolt tema ise, ülemjuhataja Laidoner, Juhan Kukk, Nikolai Köstner, vastu Jüri Jaakson ja esialgu ka välisminister Ado Birk, kes olevat soovinud uurida enne liitlaste arvamust.

237 Piip, "Tartu rahu”, 379.

238 Manuil Margulies, God interventsii, kd 3 (Berlin: Grzhebin, 1923), 118.

239 Dr. Pigrini [Jaan Poska], "Balti liit ja Poola huvid", 2.

240 Ibid.
} 
Soome välisministri Rudolf Holsti arvamust, et kui enamlased Eestit de jure tunnustaksid, siis teeksid seda mõne aja pärast ka liitlased. ${ }^{241}$ Polnud vaja uskuda enamlaste sõnadesse, et loota nende abil midagi läänes saavutada.

Moskva oli juba enne läbirääkimiste algust teatanud, et üks rahutingimus on iseseisvuse tunnustamine. Eesti rahusaatkonna ettevalmistaval koosolekul mainis Poska, et tunnustamise kohta oleks tarvis eraldi deklaratsiooni, "mis moraliliseks garantiiks oleks tulevaste kallale kippumiste vastu." ${ }^{242}$ Kuid kas sel juhul ei tulnuks tunnustada ka Nõukogude Venemaad? Seda ei tohtinud Poska arvates teha. Ta pakkus, et tunnustatakse riiki, Venemaad, mitte aga enamlikku valitsust. 5. detsembril, rahukonverentsi esimesel plenaaristungil selgus, et selline lahendus Vene poolele ei sobi. Õhtul asus Eesti rahusaatkond asja uuesti omavahel arutama. Piip luges ette lõigu Franz von Liszti rahvusvahelise õiguse õpikust, kus mainiti, et tunnustamine võib sündida ka vaikimisi. Poska rõhutas veel kord, et enamlaste tunnustamisest tuleks hoiduda, "sest muidu võiksime meie liitlaste blokaadi alla sattuda." ${ }^{243}$ Järgmisel päeval luges Poska plenaaristungil ette Eesti pakutud sõnastuse: "Lähtudes rahvaste enesemääramise põhimõttest, tunnustab Venemaa tingimusteta Eesti riigi iseseisvust ja rippumatust, nagu selle kuulutas välja Eesti Asutav Kogu 19. mail 1919. aastal ning loobub vabatahtlikult ja igaveseks ajaks igasugustest suveräänõigustest, mis kuulusid Venemaale suhetes Eesti maa ja rahvaga tema etnograafilistes ja riiklikes piirides varasema riigiõigusliku korra mõjul või rahvusvaheliste lepingute alusel, mis kaotavad siin nimetatud mõttes oma jõu tulevikus." ${ }^{244}$ Krassin vastas oma versiooniga: "Lähtudes Venemaa Sotsialistliku Föderatiivse Nõukogude Vabariigi tööliste-talupoegade valitsuse poolt korduvalt kuulutatud kõigi rahvaste vabast enesemääramise õigusest, kuni täieliku lahtilöömiseni riigist, mille hulka nad kuuluvad, tunnustab Venemaa Eestit iseseisva rippumatu riigina." ${ }^{245}$ Krassini sõnul ei saanud viidata Eesti Asutava Kogu seletusele, millega venelased polevat tutvunudki (Piip lubas neile teksti hankida). Joffe lisas, et piirid määratletakse rahuleppe teistes punktides. Muus langevat Eesti ja Vene kavad

241 RA, ERA.957.11.111, 1. 45: Oskar Kallas välisasjade komisjoni esimehele ja peaministrile, 25. november 1919.

242 RA, ERA.957.10.25, 1. 8-9: Eesti rahusaatkonna koosoleku protokoll, 5. detsember 1919.

${ }^{243}$ RA, ERA.957.10.25, 1. 11-12: Eesti rahusaatkonna koosoleku protokoll, 6. detsember 1919.

244 RA, ERA.957.10.49, 1.1: Eesti pakutud kava tunnustamist puudutava lepingupunkti kohta.

245 RA, ERA.957.10.28, 1. 28: Tartu rahukonverentsi 6. detsembri plenaaristungi protokoll. 


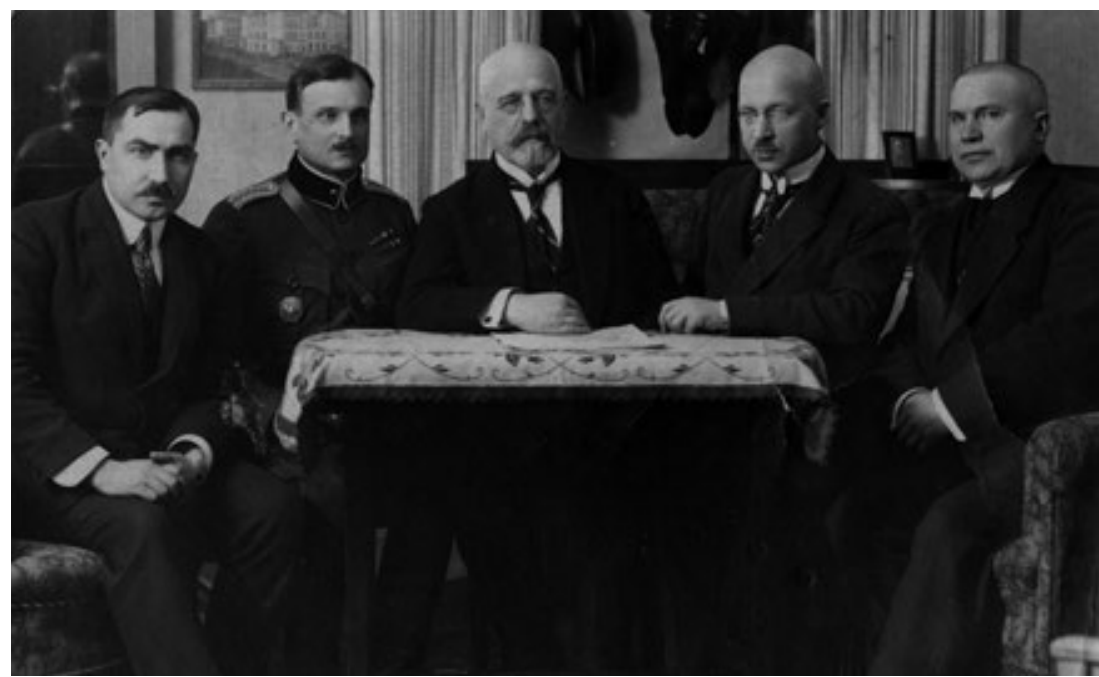

Joonis 2. Eesti delegatsioon Tartu rahu läbirääkimistel. RA, EAA.2113.1.15.45

sisuliselt kokku. Kuigi Piip nõustus, polnud see tõsi. Esiteks mainis Vene versioon Nõukogude valitsust ja vabariiki (mitte üldisemalt Venemaad), teiseks oli selles juttu Nõukogude dekreediga kuulutatud enesemääramise õigusest. Samuti ei sisaldanud Vene kava midagi õiguste loovutamise kohta.

Mõlemale poolele sobiva sõnastuse otsimiseks moodustati erikomisjon, kuhu kuulusid Joffe ja Piip. ${ }^{246}$ Just Piip oli 1917. aasta oktoobris pannud ette tugineda Nõukogude enesemääramise dekreedile ning esitanud 1918. aasta jaanuaris käsitluse, mille järgi polnud see dekreet mitte mõne eripärase nõukogude õiguse väljendus, vaid tähistas üldise rahvusvahelise põhimõtte omaksvõttu. Seetõttu ei tõrkunudki ta nähtavasti Vene versiooni eelistamise vastu. Komisjoni arutelu oli lühike. Piibu sõnul leiti väljapääs nõnda, et tunnustamist puudutava artikli kaks kava ühendati peaaegu mehaaniliselt: Vene variandist sissejuhatus ja Eesti omast ülejäänu. ${ }^{247}$ Lepingust õnnestus välja jätta osutus tööliste-talupoegade valitsusele ja rõhutus, et viimane oli enesemääramise põhimõtet kuulutanud "korduvalt". Selle üle saab tagantjärele ainult rõõmustada, sest kui Eesti delegaadid oleks täielikult nõustutud Vene sõnastusega, siis oleks Tartu rahulepingu artikkel II omandanud enamliku lendlehe ilme. ${ }^{248}$ Kadusid viited Asutava Kogu

\footnotetext{
$246 \quad$ Ibid., 32.

247 Piip, “Tartu rahu”, 391.

248 14. jaanuaril 1920 Nõukogude Venemaa ja Valgevene Nõukogude Vabariigiga sõlmitud lepingus mainiti "suure proletaarse revolutsiooni" deklareeritud enesemääramise
} 
seletusele ja etnograafilistele piiridele. Muutumatuna säilis aga eestlaste pakutud suveräänõigusi puudutav osa. See tõik osutus oluliseks. Ka lepingutesse Läti ja Leeduga jõudis Nikolai Maimi sõnastatud tingimus, mille järgi loobus Venemaa igaveseks ajaks kõigist suveräänõigustest iseseisvunud riigi maa ja rahva üle. Moskva esialgne kavatsus oli piirduda lepingus üldiste põhimõtete mainimisega ja jätta üksikasjad tulevikuks. ${ }^{249}$ Eesti nõudmisel said Venemaast lahkulöömise tagajärjed hoopis täpsema kuju.

\section{Kokkuvõte}

Hetkel, kui tunnustamise punktis kokku lepiti, valitses veel ebaselgus, kas enamlased üldse soovivad rahu teha. Järgnenud ettepanek piiride kohta oli Eestile nii ebasoodne, et Poskale ei jäänud kahtlust: enamlased ei võta rahu küsimust tõsiselt. ${ }^{250} 8$. detsembril kirjutas ta peaminister Tõnissonile, et tuleb rehkendada sõjategevuse peatse taasalgamisega. Ent isegi sellises olukorras pakkusid rahukõnelused diplomaatilisi võimalusi. Poska esialgne kavatsus oli neid kasutada, et luua tihedamaid sidemeid Balti riikide vahel. See kava läks luhta. ${ }^{251}$ Siiski lootis ta veenda soomlasi sõjalisele koostööle argumendiga, et vastasel korral on Eesti sunnitud tegema rahu, mis ohustab ka Soomet. ${ }^{252}$ Samuti sai kõnelustega mõjustada lääneliitlasi. Poska pani tähele, et ühes konservatiivses Prantsuse ajalehes nõuti Eesti tunnustamist tingimusega, et jätkataks sõda enamlaste vastu. "Kui nemad nüüd teada saavad, et meie nii kui nii sunnitud oleme edasi võitlema,” kirjutas ta Tõnissonile, "siis jätavad ehk tunnustamise mõt[t]e maha. Sellepärast oleks ehk kasulik, kui meie kartuste üle vaikiksime ja läbirääkimisi venitada püüaksime.”253 Kuna Poska mõtlemine oli nii mitmetahuline, siis pole üllatav, et isegi Ants Piip ei saanud aru, kas ta "tahab rahu tõesti

õigust. Sbornik dě̃stvuyushchih dogovorov, soglasheniǔ i konventsiŭ, zaklyuchennȳh $R$. S.F.S.R, kd 1 (Peterburg: Gosudarstvennoe izdatel'stvo, 1922), 13.

249 Chicherin, Stat' $i$ i rechi, 142.

250 RA, ERA.31.1.1570, 1. 15-16: Poska kiri peaministrile, 8. detsember 1919.

251 Dr. Pigrini [Jaan Poska], "Rahu ümber", Tallinna Teataja, 10.12.1919, 2.

252 17. detsembril palus Poska välisminister Birgil Soome valitsusele seletada, et ollakse sunnitud rahu tegema, kui põhjanaaber "aktivset osa edaspidises võitluses ei otsusta". RA, ERA.957.10.15, 1. 49: raadiogrammivahetus Birgi ja Piibu vahel. Poska viitas, et oli seda varemgi palunud. 10. detsembril oli Eesti sõjaminister August Hanko teatanud Soome välisministrile, et Eestil on vaid kaks võimalust: jätkata sõda või teha enamlastele selliseid järeleandmisi, mis "Eestimaa enamlaste käpa alla paneks". Viimane võimalus toovat kaasa ohu iseäranis Soomele. "Eesti sõjaminister Soome välisministrile", Eesti ja Soome suhted, 52.

253 RA, ERA.31.1.1570, 1. 16: Poska kiri peaministrile, 8. detsember 1919. 
saavutada, või mängib ta mingi muu arenemise ootel". ${ }^{254}$ Piibu meenutused on jätnud sügava jälje Tartu rahu eelloo käsitlemisele. Ent tema vaatenurk oli eripärane - Piip pani palju rõhku sellele, millal tehti valik "rahupoliitika" kasuks. Poska olevat selleni jõudnud 1919. aasta juulis, hakanud siis kõikuma ja naasnud endise seisukoha juurde 1920. aasta jaanuaris. ${ }^{255}$ Ülal püüti näidata, et selline käsitlus on eksitav. Poska ei näinud enda ees valikut - rahu- või sõjapoliitika. Ta pidas imetlusväärse leidlikkusega silmas kõiki hoobasid Eesti iseseisvuse kindlustamiseks. Kui Poska tõesti otsustas 1920. aasta jaanuaris rahu tegemise kasuks, siis mitte seetõttu, et sai võitu kõhklustest, vaid kuna olukord ise soosis sellist lahendust. Enamlaste pakutud tingimused paranesid läbirääkimiste käigus sedavõrd, et neist võis välja lugeda tõsist rahusoovi. ${ }^{256}$ Poska sõnul sai püsiv olla ainult õiglane rahu. Sellisele lepingule võis alla kirjutada ka siis, kui oli teada, et enamlased pakuvad seda koduste raskuste tõttu, mitte siirast poolehoiust väikerahvastele. ${ }^{257}$

Niisiis mõistis Poska hästi, et enamlastega saab teha õiglase rahu ainult väga eripärases mõttes. Tartu rahuleping oli enamlaste vaatenurgast õiglane, kuna vastas jõudude vahekorrale klassivõitluses. Viimane polnud sama mis sõjaline rindejoon. Kui oktoobris löödi tagasi Loodearmee rünnak, siis pooldas Trotski tungimist Eesti territooriumile. Lenin aga oli päri Tšitšerini arvamusega, et see oleks strateegiline viga. ${ }^{258}$ Eesmärk polnud tungida nii kaugele läände kui võimalik. 1918. aastal oli seda proovitud, nüüd anti endale aru, et see ei tõotanud edu. Sõjaline rünnak muutnuks meeleolu väikeriikides, kellega sooviti sõlmida rahu. Olid tekkinud tingimused mitte tööliste, vaid rahvaste enesemääramiseks. Kuid enamlaste poolehoid rahvaste enesemääramisele jäi sõltuma neist tingimustest. 1903. aastal oli Lenin selgitanud erinevust, mille poolest tema käsitlus enesemääramisest läks lahku kodanlik-demokraatlikust käsitlusest. Viimane püstitavat nõudmisi abstraktselt, tingimusteta, absoluutse printsiibi vaimus.

\footnotetext{
254 RA, ERA.1624.1.99, 1. 185: Ärakiri Piibu kirjast Eduard Laamanile, 21. veebruar 1925. 255 RA, ERA.1624.1.99, 1. 169: Piibu märkused tööerakonna ja Tartu rahu kohta, dateerimata.

256 Detsembris muutis Poska väga ettevaatlikuks venelaste nõudmine lähtuda mitte rahvuslikest, vaid strateegilistest piiridest. "Et ... meil mingisugust mõtet ei või olla Venemaaga sõda alustada, siis ei või strateegilise piiri nõudmine enamlaste poolt muud tähendada, kui et nemad paremat aega ära oodata tahavad, et siis uut katset teha meie riiklist iseseisvust ära hävitada. Muud põhjust ei või olla." Dr. Pigrini [Jaan Poska], "Rahu ümber", Tallinna Teataja, 16.12.1919, 2.

257 Poska sõnavõtt Asutavas Kogus 10. veebruaril 1920, Asutava Kogu III istungjärk, v 277,28 o.

258 Mattisen, Tartu rahu, 270.
} 
Marksism aga vaatavat kõike klassivõitluse muutuvalt seisukohalt. ${ }^{259}$ Tartu rahulepingus avaldus Tšitšerini väitel kompromisside tegemise suur kunst. Kõik järeleandmised, metsakontsessioonidest kullani, olevat kaudselt tehtud Suurbritanniale, kellele Eesti olevat end targalt sappa sättinud - "Ta valis väga lihtsa tee: alati kõiges koos Inglismaaga". Erinevalt väikekodanlikest prantslastest, kes viivad põhimõtted absoluutse äärmuseni, olevat inglise valitsejad jõu-usku: võitsid valged, kõneldi nendega, tugevnesid enamlased, lepiti kokku nendega. ${ }^{260}$ Samasuguse pragmaatilisusega suhtusid enamlased Eestisse. Pärast revolutsioonilise sõja vaibumist oldi valmis kooseksisteerimiseks kapitalistidega. Kuid ainult ajutiselt, jõudude vahekorra muutumiseni. Eesti ja teised piiririigid pidid püsima iseseisvate vabariikidena enesemääramise põhimõtte alusel - kuni elu ise annab sellele põhimõttele uue sisu. Omamoodi oli seegi kummardus tõdemusele, et õiguse elu on võitlus.

MÄRKSÕNAD: enesemääramise õigus; Pariisi rahukonverents; enamlased; Tartu rahuleping

Hent Kalmo on teadur Tartu Ülikooli Johan Skytte poliitikauuringute

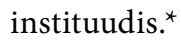

Abstract: Self-Determination in Word and Deed: Tartu vs. Paris

The Tartu Peace Treaty of 1920, signed between Estonia and Soviet Russia, has been credited with laying the foundation for stability in Eastern Europe in the interwar period. Ants Piip, a member of the Estonian delegation at Tartu, attributed this achievement to the equitable character of the agreement, comparing it favourably with the Treaty of Versailles, widely seen as a dictated peace already in the immediate aftermath of its signature. A similar view was expounded by the Soviet government, which portrayed the Tartu Peace Treaty as an expression of the principles underlying the

259 V. I. Lenin, "Rahvusküsimus meie programmis", Teosed, kd 6 (Tallinn: Eesti Riiklik Kirjastus, 1952), 412.

260 Chicherin, Stat' i i rechi, 139.

* Kirjavahetus: Hent Kalmo, Kohtu 8, 10130 Tallinn, Eesti. E-post: hrkalmo@ut.ee 
November Revolution. It especially emphasised the self-determination of peoples, proclaimed repeatedly by the Soviet government as a sine qua non for a just peace. According to the Soviet narrative, the principle of selfdetermination had been hailed by the Entente only to be later betrayed at the Paris Peace Conference. The Tartu Peace Treaty, where the principle of self-determination figured prominently in Article II, thus became, in this telling, an ideological counter model to the results of the Paris Peace Conference. Despite their anti-Bolshevik outlook, Estonian diplomats and politicians inclined towards a comparable interpretation: they had accepted the Soviet peace proposal, with the offer to recognise their right to selfdetermination and independent statehood, only after the Allies had failed to live up to their promises at Paris.

The refence to the principle of self-determination in the Tartu Peace Treaty has not received much attention from historians. As Lauri Mälksoo has noted, it remains a well-nigh forgotten chapter in the history of international law. Mälksoo argued that the reference is all the more noteworthy since the Soviet government gave the principle a remarkably wide scope, joining to it the right to secession, which was not yet enshrined in general international law at the time. Assuming that the principle of selfdetermination was mentioned in the Tartu Peace Treaty at the initiative of the Soviet side, Mälksoo suggested two motives that might have prompted it: the need to recognise the fait accompli of Estonian independence, and the wish to justify within Russia itself the decision to relinquish territories that had formerly belonged to the Tsarist Empire. This article shows that the Estonian side was also keen to refer to the principle of self-determination, quite independently of Soviet wishes, as demonstrated by a draft peace treaty drawn up two months prior to the start of the Tartu negotiations by a commission of experts convened by the Estonian Minister of Foreign Affairs. This fact is indicative of the broader diplomatic significance that the Estonian delegation - and its head, Jaan Poska, in particular - attached to peace talks with the Bolsheviks. The article demonstrates that Poska did not start the negotiations in December of 1919 with the sole aim of signing a peace treaty with Soviet Russia. Just as important, if not more so, was the prospect of using the talks to convince the Entente to recognise Estonian independence de jure.

The Estonian government had founded its claim to international recognition on the principle of self-determination. Upon the outbreak of the Bolshevik revolution, the Estonian Provisional Assembly had availed itself of the Soviet decree proclaiming the right of all peoples of Russia to selfdetermination, including secession and the formation of a separate state. 
Without being confident in the resolve of the Soviet government to adhere to the letter of its public pronouncements, Estonian politicians nonetheless saw the usefulness of invoking the decree, since the latter could be seen as ratifying Estonia's decision to secede from Russia. They were already positioning themselves vis-à-vis the Entente Powers, whose freedom to recognise the nascent republic was constrained by rules of international law regarding the validity of secession. The principle of self-determination had great value for a seceding state, especially in circumstances where the mother country did not have a lawful government and was thus unable to consent to any separation of territories (as Russia was regarded in the eyes of most governments at the end of 1917). The Estonian position was buttressed by a string of diplomatic statements made by the Entente Powers in 1918, assuring Estonia that its status would be determined at a forthcoming peace conference in accordance with the principle of self-determination.

Such assurances filled Estonian diplomats with great optimism when they set out for the Paris Peace Conference at the beginning of 1919. The principle of self-determination was tantamount to independence in their mind. It was therefore with growing disappointment that they observed the unwillingness of France and Great Britain to recognise their independence at Paris, intent as the latter were to reconstitute their former eastern ally. This is not to say that Estonian claims were completely ignored. British politicians did not think that they were failing to honour their promises when offering Estonia internationally guaranteed autonomy, under the aegis of the League of Nations, instead of independence. Autonomy did not satisfy Estonians, however, who were canvassing all options at their disposal to arrive at their aim. The quest for 'other ways', beginning in earnest in the summer of 1919, has been mostly interpreted by scholars as a decision to reach a peace settlement with the Bolsheviks. The article shows that the Estonian strategy was more multi-faceted. International recognition remained their chief aim, and their receptiveness to Bolshevik peace feelers should be seen in this light. The emphasis placed on the principle of self-determination from the very start of negotiations with Soviet Russia in September of 1919 was a part of this Western-directed diplomatic approach. The Bolsheviks had their own aims in mind when foregrounding this principle. The consternation that the Treaty of Versailles had caused in Germany offered them an opportunity to depict the Paris Peace Conference as the latest manifestation of Great Power imperialism, to which the Soviet proposal of a 'democratic peace' (no annexations, no contributions, self-determination to all peoples) was allegedly the only viable alternative. 
The peace talks between Estonia and Soviet Russia were thus caught in an ideological struggle between the Soviet government and the Western Allies concerning 'just peace'. But they also fitted in with the - apparently contrary - Soviet strategy of abandoning outright military aggression and preparing the ground for 'peaceful coexistence' with capitalist states, with a view to buttressing the Soviet regime economically. The reference to the principle of self-determination in the Tartu Peace Treaty can be explained by all the considerations mentioned above. The Estonians had their sights set on reinforcing their international status by tying it to the principle. The Bolsheviks were showcasing their adherence to 'democratic peace' and contrasting their favourable attitude to small peoples with the hypocrisy of the Great Powers (the fact that it was Soviet Russia that had initiated the war with unprovoked military aggression in 1918 was conveniently ignored). Moreover, on a less public level, Soviet Russia was signalling that it was willing to consent to self-determination in the Russian borderlands in order to reach an agreement with its Western foes, and that it would rely on the long-term superiority of the Bolshevik system in lieu of head-to-head collision with capitalist states. In this last sense, the Treaty of Tartu marks a strategic turn for the Soviet government that became so consequential for the $2 \mathrm{O}^{\text {th }}$ century that the treaty with Estonia acquires truly foundational significance.

Keywords: principle of self-determination; Paris Peace Conference; Tartu Peace Treaty; Bolsheviks

Hent Kalmo is Research Fellow at the Johan Skytte Institute of Political Studies, University of Tartu.*

* Correspondence: Hent Kalmo, Kohtu 8, 10130 Tallinn, Eesti. E-mail: hrkalmo@ut.ee 
